\title{
Adriatic calcarean sponges (Porifera, Calcarea), with the description of six new species and a richness analysis
}

\author{
Michelle KLAUTAU ${ }^{1, *, a}$, Mirna IMEŠEK ${ }^{2, *, a}$, Fernanda AZEVEDO ${ }^{3}$, Bruna PLEŠE $^{4}$, \\ Vedran NIKOLIĆ ${ }^{5} \&$ Helena ĆETKOVIĆ ${ }^{6}$ \\ ${ }_{1,3}^{13}$ Universidade Federal do Rio de Janeiro, Instituto de Biologia, Departamento de Zoologia, \\ Av. Carlos Chagas Filho 373, Cidade Universitária, 21941-902 Rio de Janeiro (RJ), Brazil. \\ ${ }^{2,4,6}$ Ruđer Bošković Institute, Division for Molecular Biology, \\ Bijenička cesta 54, 10002 Zagreb, Croatia. \\ ${ }^{5}$ Institute of Oceanography and Fisheries, Laboratory for Benthos, \\ P.O. Box 500, 21000, Split, Croatia. \\ ${ }^{\text {a Equally contributed }}$ \\ *Corresponding authors: mklautau@biologia.ufrj.br; mimesek@irb.hr \\ ${ }^{3}$ E-mail: nandaporifera@gmail.com \\ ${ }^{4}$ E-mail: bplese@irb.hr \\ ${ }^{5}$ E-mail: nikolic@izor.hr \\ ${ }^{6}$ E-mail: cetkovic@irb.hr

\footnotetext{
${ }^{1}$ urn:Isid:zoobank.org:author:C6BB3D65-7166-4A2A-AF2B-7F13EE94F485

${ }^{2}$ urn:lsid:zoobank.org:author:5461D38C-E1B5-48B1-A41B-0134F337A143

${ }^{4}$ urn:lsid:zoobank.org:author:C9E3BEB1-01E6-44A4-807B-4800E9393C09

${ }^{5}$ urn:lsid:zoobank.org:author:84828CF3-6BA3-4541-AEF2-24422CEA0179

${ }^{6}$ urn:lsid:zoobank.org:author:BD5D084E-8AAE-4CBA-991B-0901EB6C8DE1
} \\ ${ }^{3}$ urn:lsid:zoobank.org:author:DC0BE6B4-F24F-4765-BA2B-ED17D774B2B7
}

\begin{abstract}
In this study we analyze the calcarean sponge diversity of the Adriatic Sea, the type locality of some of the first described species of calcarean sponges. Morphological and molecular approaches are combined for the taxonomic identification. Our results reveal six species new to science and provisionally endemic to the Adriatic Sea (Ascandra spalatensis sp. nov., Borojevia croatica sp. nov., Leucandra falakra sp. nov., L. spinifera sp. nov., Paraleucilla dalmatica sp. nov., and Sycon ancora sp. nov.), one species previously known only from the Southwestern Atlantic (Clathrina conifera), and three already known from the Adriatic Sea (Ascaltis reticulum, Borojevia cerebrum, and Clathrina primordialis). We confirm the presence of the alien species Paraleucilla magna in the Adriatic and again record Clathrina blanca, C. clathrus, and C. rubra. We emend the description of the genus Ascaltis, propose a lectotype for Borojevia cerebrum and synonymise $B$. decipiens with $B$. cerebrum. A checklist of all calcarean species previously and currently known from the Adriatic Sea (39 species) is given. The Central Adriatic is indicated as the richest calcarean sponge fauna sector; however, the biodiversity of this class is underestimated in the whole Adriatic Sea and new systematic surveys are desirable.
\end{abstract}

Keywords. Porifera, Calcarea, Adriatic Sea, molecular taxonomy, morphological taxonomy. 
Klautau M., Imešek M., Azevedo F., Pleše B., Nikolić V. \& Ćetković H. 2016. Adriatic calcarean sponges (Porifera, Calcarea), with the description of six new species and a richness analysis. European Journal of Taxonomy 178: 1-52. http://dx.doi.org/10.5852/ejt.2016.178

\section{Introduction}

Although the biodiversity of sponges of the Mediterranean Sea has been studied for a long time (e.g., Schmidt 1862, 1864; Haeckel 1872), some regions and sponge taxa have remained rather neglected. The Adriatic Sea is one of the seven eco-regions of the Mediterranean Province (Spalding et al. 2007) and is considered a biodiversity hotspot (Bianchi et al. 2012) of major ecological importance. It forms a very narrow, semi-enclosed basin in the northernmost part of the Mediterranean Sea, subdivided into three sectors: Northern Adriatic, Central Adriatic and Southern Adriatic (Bianchi \& Morri 2000). The karst limestone is known for forming unique habitats such as caves, overhangs and pits, which are rather inaccessible and often inhabited by a number of invertebrate groups, including calcarean sponges. They are generally less investigated, mainly because of a smaller number of experts involved in their taxonomy, and consequently a large number of species is still unknown. Several calcarean species are known from the Mediterranean, including the Adriatic (see Pansini \& Longo 2008), but literature data on these Adriatic species is very scarce or difficult to access, moreover lacking a comprehensive and detailed morphological and molecular descriptions.

Dohrmann et al. (2006), Rossi et al. 2011 and Voigt et al. (2012) demonstrated that modern methods of DNA taxonomy are necessary to highlight the phylogenetic signals in morphological features of, mostly ambiguous, calcarean sponges. Thus, expanding the number of analysed species helps in defining the species-specific morphological features related to certain phylogenetic traits (Rossi et al. 2011). A clear and precise taxonomy, based on molecular analyses, represents a strong foundation for accurate systematics changes on different taxonomic levels (Klautau et al. 2013).

Some of the first studies on the class Calcarea were done along the Dalmatian coast (e.g., Schmidt 1862, 1864; Haeckel 1870, 1872). Therefore, the Adriatic Sea is the type locality of many of the first known species of calcarean sponges (Haeckel 1870, 1872). Nevertheless, a large number of the original descriptions are fragmentary and many type specimens were lost over time. Hence, in addition to the importance of species diversity records for this eco-region, it is crucial to establish new collections and descriptions of Adriatic calcarean sponges, preferably with detailed morphological and molecular analyses.

In the present work, we study the calcarean sponge diversity of the Adriatic Sea and re-describe some of Haeckel's species using morphological and DNA taxonomy. Furthermore, we performed an analysis of species richness and compiled a checklist comprising all species previously known from the Adriatic Sea (32 species), together with the new data provided here $(7$ species). Our results indicate that the calcarean sponge fauna of the Adriatic Sea is still underestimated and new systematic surveys including molecular markers are very welcome.

\section{Materials and methods}

The material studied is preserved in the following collections:

$\mathrm{BMNH}=$ The Natural History Museum, London, UK

$\mathrm{GW} \quad=$ Gert Wörheide

IRB $=$ Institut Ruđer Bošković, Zagreb, Croatia

MNRJ = Museu Nacional do Rio de Janeiro, Brazil

PMJ = Phyletisches Museum Jena, Germany

PMR = Prirodoslovni Muzej Rijeka, Croatia 


$\begin{aligned} \mathrm{QM} & =\text { Queensland Museum, Australia } \\ \mathrm{SAM} & =\text { South Australian Museum, Australia } \\ \text { UFRJPOR }= & \text { Sponge collection of the Biology Institute of the Universidade Federal do Rio de } \\ & \text { Janeiro, Brazil } \\ \text { ZMAPOR }= & \text { Zoölogisch Museum, Instituut voor Systematiek en Populatiebiologie, Amsterdam, The } \\ & \text { Netherlands } \\ \text { ZMB } & \text { Museum für Naturkunde and der Universität Humboldt zu Berlin, Germany }\end{aligned}$

Whenever possible, specimens were divided among two different collections. In such cases the specimens received two register numbers. Both numbers are indicated in the text.

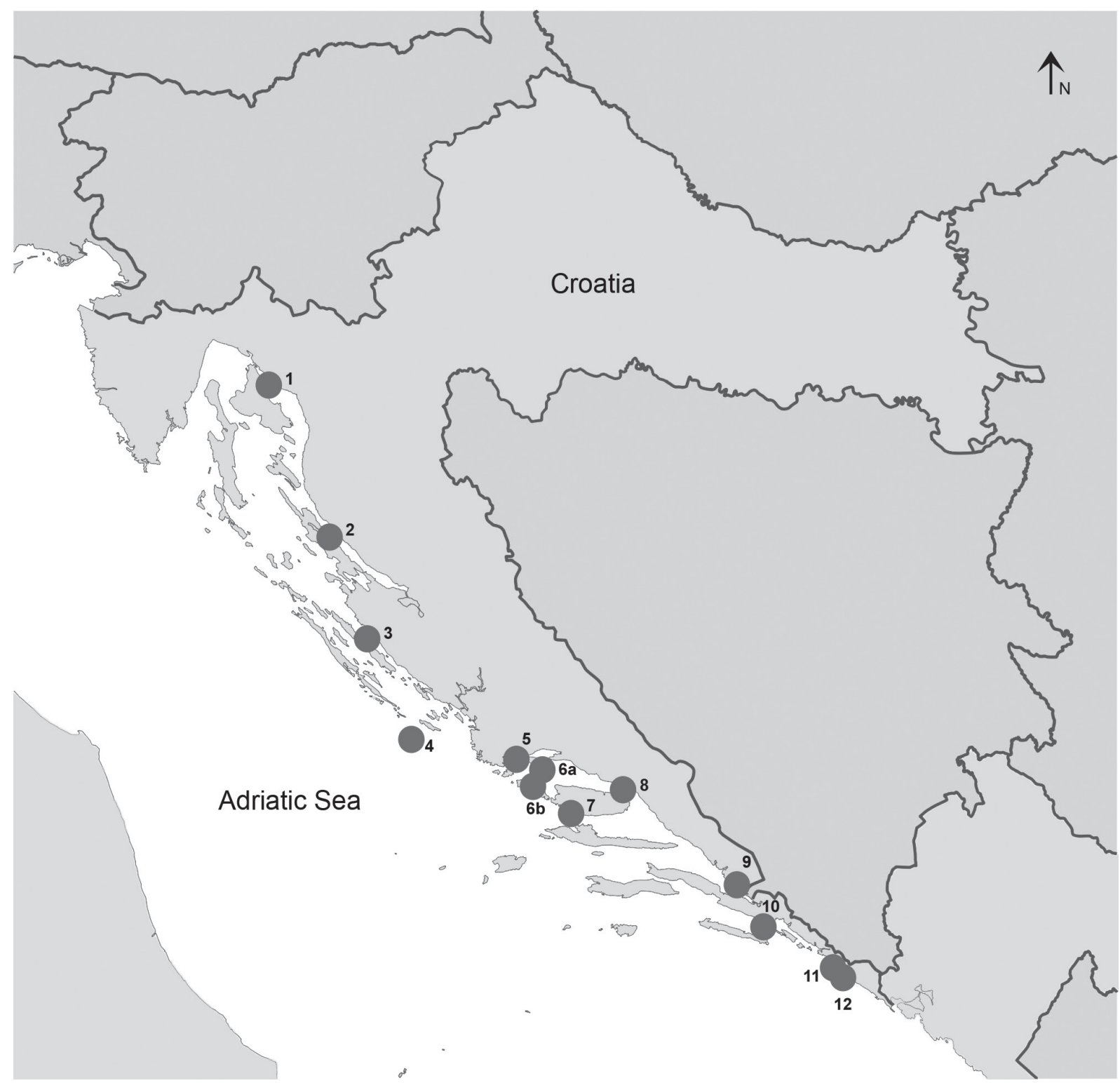

Fig. 1. Map of the Croatian coast. Studied locations along the coast are marked with gray circles and numbers. 1. Near Selce. 2. Island of Pag. 3. Near Zadar. 4. Island of Blitvenica. 5. Near Split. 6a-b. Island of Čiovo. 7. Island of Brač. 8. Vrulja Cove. 9. Port of Ploče. 10. Prapratno Cove. 11. Near Dubrovnik. 12. Island of Lokrum. 


\section{Sampling and morphological analyses}

Calcarean sponges were collected by SCUBA in 12 localities along the Croatian coastline (Fig. 1). Sponges were fixed and preserved in 96\% ethanol. Spicule preparations and sections followed standard procedures (Wörheide \& Hooper 1999; Klautau \& Valentine 2003).

Length and width at the base of each actine of the spicules were measured. The results are presented in tabular form, featuring length (minimum [min], mean, standard deviation [sd] and maximum [max]), width (minimum [min], mean, standard deviation [sd] and maximum [max]) and sample size (n). Photomicrographs were taken with a digital camera mounted on a Zeiss Axioskop microscope. Micrographs were taken with a JEOL, JSM-6510 scanning electron microscope (SEM) at the Biology Institute (Universidade Federal do Rio de Janeiro).

Specimens are deposited in the sponge collections of the Biology Institute / Universidade Federal do Rio de Janeiro, Brazil, the Natural History Museum in Rijeka, Croatia, and at the Ruđer Bošković Institute, Croatia (Table 1).

\section{DNA isolation, amplification, cloning and sequencing}

Total DNA was extracted from $0.05-0.3 \mathrm{~g}$ of tissue, using the E.Z.N.A. Forensic DNA Kit (Omega Bio-tek) or G-spin Genomic DNA Extraction Kit (Intron) following the manufacturer's protocol. The ITS1-5.8S-ITS2 rDNA region was amplified by polymerase chain reaction (PCR) using primers 18SF (5'-TCATTTAGAGGAAGTAAAAGTCG-3') plus 5.8SR (5'-GCGTTCAAAGACTCGATGATTC-3') (Lôbo-Hajdu et al. 2004) and ITS2F (5'-CGGCTCGTGCGTCGATGAAGAAC-3') plus ITS2R (5'-CGCCGTTACTGGGGGAATCCCTGTTG-3') (Harcet et al. 2010). Partial 28SrDNA gene sequences were amplified with two pairs of primers, NL4F (5'-GACCCGAAAGATGGTGAACTA-3') plus NL4R (5'-ACCTTGGAGACCTGATGCG-3') (Nichols 2005), and primers CAL-28SFW (5'-GKCGGATCCGAAYGGACCG-3') plus CAL28SRV (5'-CCTCTAATCATTCGCTTTACC-3') designed at the Laboratory of Molecular Genetics of the Ruđer Bošković Institute, based on multiple alignments with the sequences available from GenBank.

PCR reactions were performed under the following conditions: $3 \mathrm{~min} / 95^{\circ} \mathrm{C}, 30$ cycles $\left(30 \mathrm{~s} / 94{ }^{\circ} \mathrm{C}, 45\right.$ $\mathrm{s} / 55^{\circ} \mathrm{C}, 90 \mathrm{~s} / 70{ }^{\circ} \mathrm{C}$ ) and final elongation $10 \mathrm{~min} / 72{ }^{\circ} \mathrm{C}$. Reaction mixtures containing $2.5 \mu 1$ of $10 \times \mathrm{PCR}$ buffer, $3 \mu \mathrm{MgCl}_{2}(25 \mathrm{mM}), 0.8 \mu \mathrm{l}$ of each primer $(10 \mathrm{mM}), 0.5 \mu \mathrm{dNTPs}(10 \mathrm{mM}$ each), 1 unit of Taq-DNA polymerase and 100-150 ng template. The quality and quantity of the amplified DNA were estimated by agarose gel electrophoresis. PCR products were purified from gel using QIAquick Gel Extraction Kit (Qiagen) and directly sequenced using the ABI PRISM 3100 automatic sequencer and ABI PRISM BigDye Terminator v. 3.1 Ready Reaction Cycle Sequencing Kit (Applied Biosystems). In a few cases, the outcomes of the sequencing reaction were mixed peaks caused by non-target DNA contamination, such as bacteria or algae, which were identified using BLAST network service (http:// www.ncbi.nlm.nih.gov/). These regions were ligated with the pGEM-T Vector Kit (Promega), cloned into XL1-Blue competent cells and up to three clones were purfied using the QIAprep Spin Miniprep Kit (Qiagen) and sequenced.

\section{Sequence alignment and phylogenetic reconstruction}

Cloned sequences were assembled using Lasergene processing software (DNASTAR Inc., Madison, WI, USA) and checked manually for sequencing errors. The BLAST network service (http://www.ncbi. nlm.nih.gov/) was used for sequence homology searches. Multiple alignments were performed with the Q-INS-i option of the MAFFT program (Katoh \& Standley 2013), using score matrix $200 \mathrm{PAM} / \mathrm{k}=2$, gap penalty 1.53 and offset value 0 . Alignments were run through a Gblocks v. $0.91 \mathrm{~b}$ server under less stringent parameters (Castresana 2000) to exclude poorly aligned regions from further analyses. Two 
KLAUTAU M. et al., Adriatic calcarean sponges (Porifera, Calcarea)

Table 1. Specimens included in the phylogenetic analyses with collection sites, voucher numbers and GenBank accession numbers. *Specimens with newly generated DNA sequences.

\begin{tabular}{|c|c|c|c|c|}
\hline \multirow{2}{*}{$\begin{array}{l}\text { Species } \\
\text { CALCINEA }\end{array}$} & \multirow[t]{2}{*}{ Collection site } & \multirow[t]{2}{*}{ Voucher number } & \multicolumn{2}{|c|}{$\begin{array}{l}\text { GenBank accession } \\
\text { number }\end{array}$} \\
\hline & & & ITS & $28 \mathrm{~S}$ \\
\hline Arthuria hirsuta & Cape Verde & ZMAPOR07061 & KC843431 & - \\
\hline Arthuria hirsuta & Cape Verde & ZMAPOR 07103 & КC985143 & - \\
\hline Arthuria spirallata & Peru & MNRJ 13652 & КС985140 & - \\
\hline Arthuria spirallata & Peru & MNRJ 11414 & KC985142 & - \\
\hline Ascaltis reticulum & Mediterranean Sea & UFRJPOR6258 & HQ588973 & - \\
\hline Ascaltis reticulum & Mediterranean Sea & UFRJPOR6260 & HQ588977 & - \\
\hline Ascaltis reticulum* & Adriatic Sea & PMR-13739 =UFRJPOR6870 & KP740022 & KP739998 \\
\hline Ascandra contorta & Mediterranean Sea & UFRJPOR6327 & HQ588970 & - \\
\hline Ascandra corallicola & Norway & UFRJPOR6329 & HQ588994 & - \\
\hline Ascandra falcata & Mediterranean Sea & UFRJPOR5856 & HQ588962 & - \\
\hline Ascandra falcata & Mediterranean Sea & UFRJPOR6320 & HQ588963 & - \\
\hline Ascandra spalatensis sp. nov.* & Adriatic Sea & PMR-17806 =UFRJPOR7540 & KP740024 & KP740003 \\
\hline Borojevia cf. aspina & Brazil & UFRJPOR5211 & HQ588969 & - \\
\hline Borojevia cf. aspina & Brazil & UFRJPOR5245 & HQ588998 & - \\
\hline Borojevia brasiliensis & Brazil & UFRJPOR5214 & HQ588978 & - \\
\hline Borojevia brasiliensis & Brazil & UFRJPOR5230 & HQ588999 & - \\
\hline Borojevia cerebrum & Mediterranean Sea & UFRJPOR6322 & HQ588964 & - \\
\hline Borojevia cerebrum & Mediterranean Sea & UFRJPOR6323 & HQ588971 & - \\
\hline Borojevia cerebrum & Mediterranean Sea & UFRJPOR6324 & HQ588975 & - \\
\hline Borojevia cerebrum* & Adriatic Sea & IRB-CLB26 & KP740029 & KP740008 \\
\hline Borojevia cerebrum* & Adriatic Sea & IRB-CLB32 & KP740031 & KP740010 \\
\hline Borojevia cerebrum* & Adriatic Sea & PMR-17808 & KP740030 & KP740009 \\
\hline Borojevia cerebrum* & Adriatic Sea & IRB-CLB33 = UFRJPOR7539 & KP740032 & KP740011 \\
\hline Borojevia croatica sp. nov.* & Adriatic Sea & PMR-13740 = UFRJPOR6864 & KP740020 & KP739995 \\
\hline Borojevia croatica sp. nov.* & Adriatic Sea & PMR-13741 = UFRJPOR6865 & KP740021 & KP739997 \\
\hline Borojevia croatica sp. nov.* & Adriatic Sea & IRB-CLB6 & KP740023 & KP740002 \\
\hline Borojevia croatica sp. nov.* & Adriatic Sea & IRB-CLB17 & KP740026 & KP740005 \\
\hline Borojevia croatica sp. nov.* & Adriatic Sea & IRB-CLB18 & KP740027 & KP740006 \\
\hline Borojevia croatica sp. nov.* & Adriatic Sea & IRB-CLB19 & KP740028 & KP740007 \\
\hline Clathrina adusta & GBR, Wistari Reef & QM G313665 & - & JQ272288 \\
\hline Clathrina aphrodita & Peru & MNRJ 14180 & KC985137 & - \\
\hline Clathrina aphrodita & Peru & MNRJ 12994 & KC985138 & - \\
\hline Clathrina aurea & Brazil & MNRJ 8998 & HQ588968 & - \\
\hline Clathrina aurea & Brazil & MNRJ 8990 & HQ588958 & - \\
\hline Clathrina antofagastensis & Chile & MNRJ 9289 & HQ588985 & - \\
\hline Clathrina antofagastensis & Peru & MNRJ 11294 & KF002722 & - \\
\hline Clathrina blanca & Adriatic Sea & PMR-14307 & KC479087 & KC479085 \\
\hline Clathrina blanca* & Adriatic Sea & PMR-13744 & KP740017 & KP740000 \\
\hline Clathrina clathrus & Mediterranean Sea & UFRJPOR6315 & HQ588974 & - \\
\hline Clathrina clathrus & Mediterranean Sea & UFRJPOR6325 & HQ588965 & - \\
\hline Clathrina clathrus & Mediterranean Sea & UFRJPOR6326 & HQ588972 & - \\
\hline Clathrina clathrus & Adriatic Sea & PMR-14308 & KC479089 & KC479083 \\
\hline Clathrina clathrus* & Adriatic Sea & IRB-CLB12 & KP740025 & KP740004 \\
\hline Clathrina clathrus* & Adriatic Sea & PMR-13745 & KP740015 & KP740001 \\
\hline Clathrina conifera & Brazil & MNRJ 8997 & HQ588957 & - \\
\hline Clathrina conifera & Brazil & MNRJ 8991 & HQ588959 & - \\
\hline Clathrina conifera* & Adriatic Sea & PMR-13738 = UFRJPOR6869 & KP740019 & KP739994 \\
\hline Clathrina conifera* & Adriatic Sea & PMR-17807 & KP740033 & KP740012 \\
\hline Clathrina conifera* & Adriatic Sea & IRB-S2 = UFRJPOR7541 & KP740034 & KP740013 \\
\hline Clathrina conifera* & Adriatic Sea & IRB-S3 = UFRJPOR7542 & KP740035 & KP740014 \\
\hline Clathrina coriacea & Norway & UFRJPOR6330 & HQ588986 & - \\
\hline Clathrina fjordica & Chile & MNRJ 8143 & HQ588984 & - \\
\hline Clathrina helveola & Australia & QMG313680 & HQ588988 & AM180987. \\
\hline Clathrina hispanica & Mediterranean Sea & UFRJPOR6305 & KC843432 & - \\
\hline Clathrina lacunosa & Norway & UFRJPOR6334 & HQ588991 & _ \\
\hline Clathrina lacunosa & Norway & UFRJPOR6335 & HQ588992 & - \\
\hline Clathrina luteoculcitella & Australia & QMG313684 & - & AM180988. \\
\hline Clathrina peruana & Peru & MNRJ 13144 & KC985134 & - \\
\hline Clathrina peruana & Peru & MNRJ 12839 & KC985135 & - \\
\hline Clathrina primordialis & Adriatic Sea & PMR-14305 & KC479086 & KC479084 \\
\hline Clathrina primordialis* & Adriatic Sea & IRB-CLB3 = UFRJPOR6863 & KP740016 & KP739996 \\
\hline
\end{tabular}




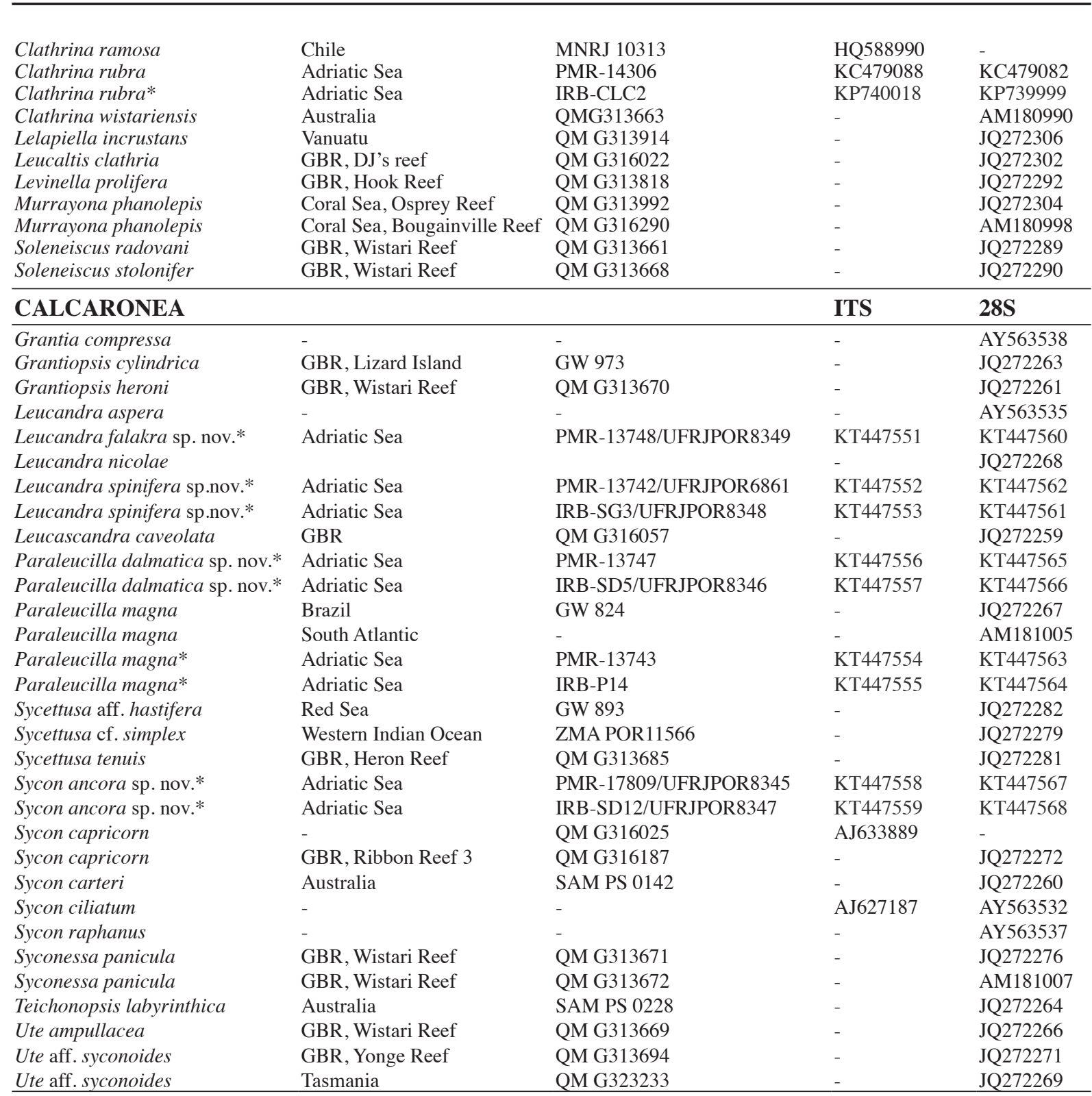

different methods were applied for phylogenetic reconstruction: maximum likelihood (ML) and Bayesian inference (BI). The Akaike Information Criterion (AIC) implemented in jModeltest 3.7 (Guindon \& Gascuel 2003; Darriba et al. 2012) was used to select the best-fit models of sequence evolution. The models were chosen for each dataset as follows: for $28 \mathrm{~S}$ analysis, $\mathrm{GTR}+\mathrm{I}+\mathrm{G}$ and $\mathrm{TrN}+\mathrm{I}+\mathrm{G}$ models were chosen for Calcinea and Calcaronea, respectively; for ITS analysis, the $\operatorname{TrN}+\mathrm{G}$ model was chosen for both datasets. Phylogenetic analyses were performed in PhyML 3.0 (Guindon et al. 2010), where datasets were analysed by the ML method. Bootstrap tests of phylogeny were performed with 1000 replicates. Bayesian MCMC analyses were performed in MrBayes v. 3.1.2. (Huelsenbeck \& Ronquist 2001), considering the same models for given datasets. Two parallel runs each comprising four Markov chains were run for 1,000,000 generations with a sampling frequency of one in every 100 trees; a consensus tree was constructed based on the trees sampled after burn-in of 100,000. Phylogenetic trees were generated separately for each dataset, rooted at midpoint and displayed in FigTree v. 1.4.2 (http:// 
tree.bio.ed.ac.uk/software/figtree/). Obtained sequences were submitted to GenBank under the accession numbers KP739994-KP740035 and KT447551-KT447568 (Table 1).

\section{Analysis of species richness}

A richness analysis of all calcarean species present in the Adriatic Sea was performed using DIVA-GIS version 7.5, a free computer program for mapping and analyzing biodiversity data (http://www.diva-gis. org/) (Hijmans et al. 2012). Menu options chosen for this analysis were: species (parameters), $0.5 \times 0.5$ degrees (cell size) and simple (point to grid procedure).

\section{Results}

\section{Species list}

Ascaltis reticulum (Schmidt, 1862)

Ascandra spalatensis sp. nov.

Borojevia cerebrum (Haeckel, 1872)

Borojevia croatica sp. nov.

Clathrina conifera Klautau \& Borojević, 2001

Clathrina primordialis (Haeckel, 1872)

Leucandra falakra sp. nov.

Leucandra spinifera sp. nov.

Paraleucilla dalmatica sp. nov.

Sycon ancora sp. nov.

\section{Taxonomy}

Class Calcarea Bowerbank, 1864

Subclass Calcinea Bidder, 1898

Genus Ascaltis Haeckel, 1872

Ascaltis reticulum (Schmidt, 1862)

Fig. 2; Table 2

Nardoa reticulum Schmidt, 1862: 18.

Tarrus reticulatus Haeckel, 1870: 244.

Nardopsis reticulum Haeckel, 1870: 247.

Ascandra reticulum Haeckel, 1872: 87.

Olynthus reticulum Haeckel, 1872: 88.

Clistolynthus reticulum Haeckel, 1872: 88.

Soleniscus reticulum Haeckel, 1872: 88.

Nardorus reticulum Haeckel, 1872: 88.

Tarrus reticulum Haeckel, 1872: 88.

Auloplegma reticulum Haeckel, 1872: 88.

Ascometra reticulum Haeckel, 1872: 88.

Ascandra retiformis Haeckel, 1872: 88.

Ascandra reticulata Haeckel, 1872: 88.

Clathrina reticulum Minchin, 1896: 359.

Ascandra hermesi Breitfuss, 1897a: 39.

Leucosolenia hermesi Dendy \& Row, 1913: 722.

Nardoa reticulum - Schmidt 1869: 91; 1870: 73.

Ascandra reticulum - Vosmaer 1881: 5. — Lendenfeld 1891: 39. — Breitfuss 1897b: 214; 1898a: 23; 1898b: 92. — Brøndsted 1914: 530. 
Leucosolenia reticulata - Dendy \& Row 1913: 723. - Breitfuss 1932: 243.

Leucosolenia reticulum - Dendy \& Row 1913: 723. - Breitfuss 1930: 275; 1932: 243; 1935: 14. Topsent 1934: 9; 1936: 22. — Hôzawa 1940: 32. — Arndt 1941: 4. — Tanita 1942: 82; 1943: 386. — Burton 1963: 200.

Ascandra retiformis - Breitfuss 1932: 243

Leucosolenia hermesi - Tanita 1942: 82.

Clathrina reticulum - Borojević 1967: 189. — Borojević \& Peixinho 1976: 993. — Borojević \& BouryEsnault 1987: 12. — Klautau \& Valentine 2003: 36. — Longo \& Pronzato 2011: 230. — Muricy et al. 2011: 34.

Ascaltis reticulum - Klautau et al. 2013: 452.

\section{Original type locality}

ADRIATIC SEA: Zara (Croatian: Zadar) and Sebenico (Croatian: Šibenik).
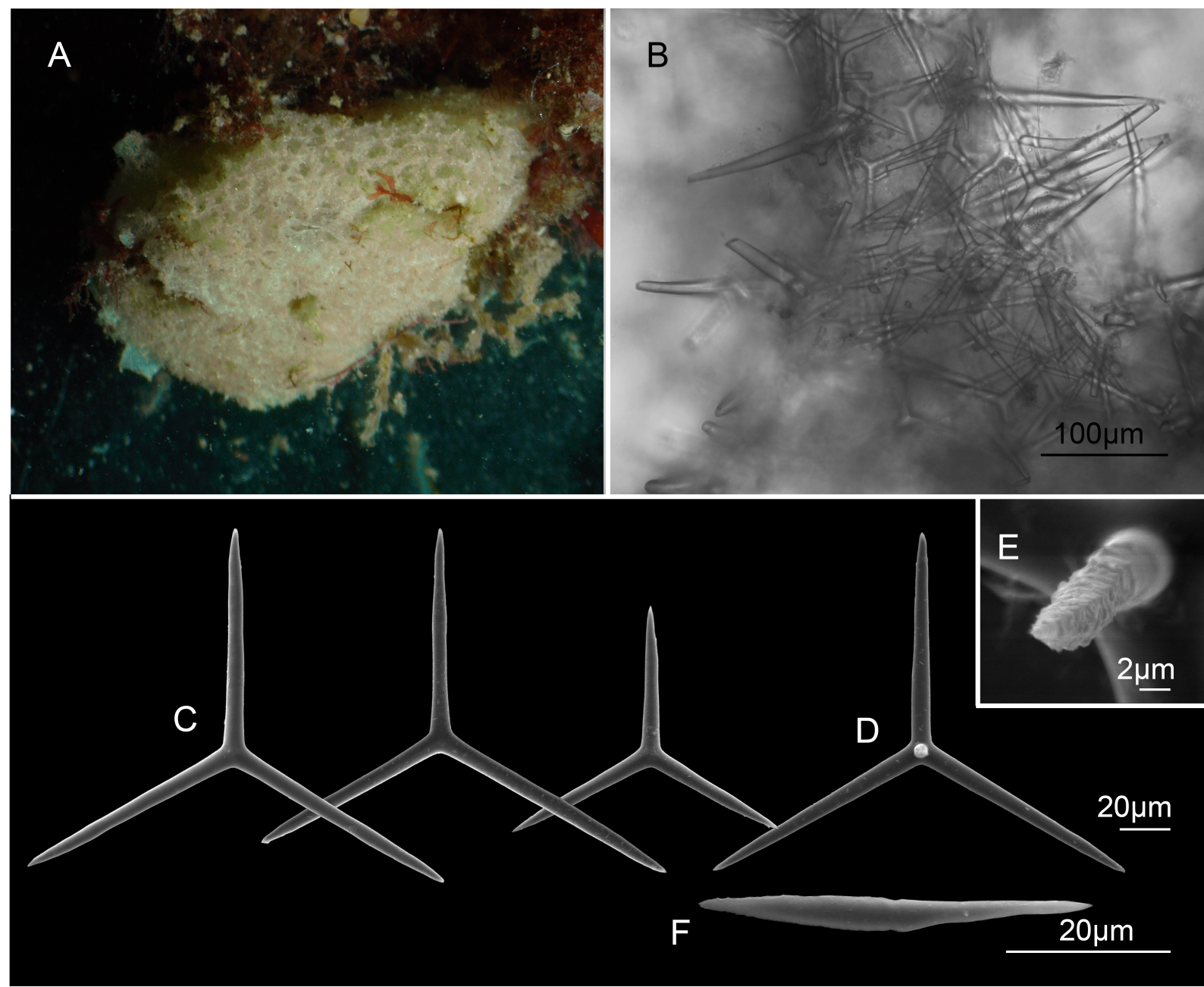

Fig. 2. Ascaltis reticulum (PMR $13739=$ UFRJPOR 6870). A. Specimen in situ. B. Section showing the perpendicular arrangement of diactines. C. Regular triactines. D. Regular tetractine. E. Apical actine of a tetractine covered with short spines. F. Diactine. 
KLAUTAU M. et al., Adriatic calcarean sponges (Porifera, Calcarea)

Table 2. Spicule measurements of Ascaltis reticulum (Schmidt, 1862) (PMR-13739 = UFRJPOR 6870).

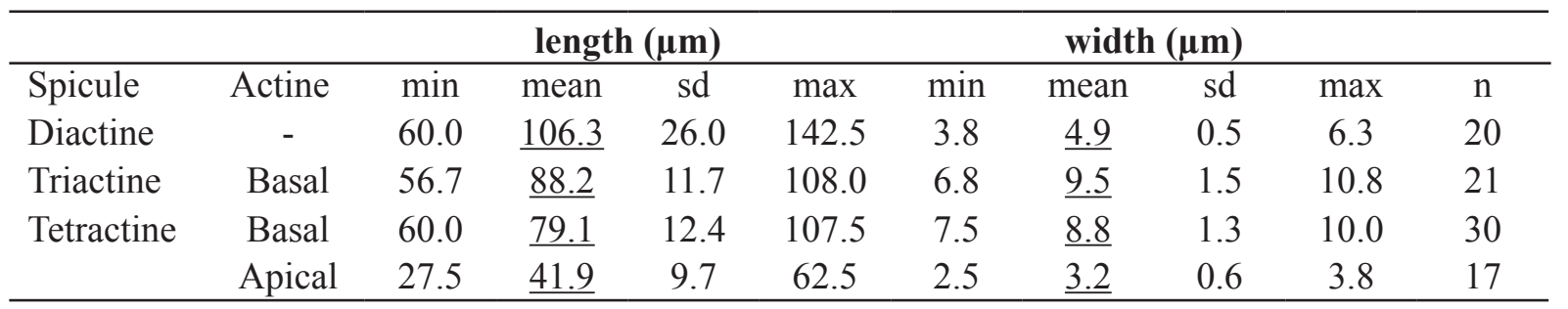

\section{Type specimen}

FRANCE: Banyuls-sur-Mer, Pyrenées, E.A. Minchin Collection (BMNH 1896.9.15.13, neotype proposed by Klautau \& Valentine 2003).

\section{Material examined}

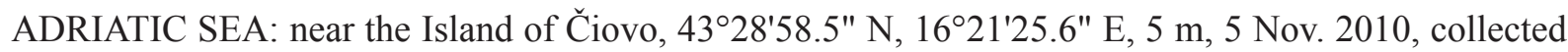
by B. Pleše and V. Nikolić (PMR-13739 = UFRJPOR 6870).

\section{Colour}

White in life and white in ethanol.

\section{Description}

Cormus is composed of regular and tightly anastomosed tubes. Water-collecting tubes are present (Fig. 2A). As the specimen was fragmented, it was not possible to observe the pseudoatrium. The skeleton is composed of one category of triactines, one of tetractines and diactines. Diactines are organised in tufts of two to five spicules, perpendicularly disposed in the tubes (Fig. 2B). Triactines are the most abundant spicules.

\section{Spicules (Table 2)}

TRIACTINES. Regular (equiangular and equiradiate). Actines are slightly conical to cylindrical, with sharp tips (Fig. 2C). Size: 88.2/9.5 $\mu \mathrm{m}$.

TETRACTINES. Regular (equiangular and equiradiate). Actines are slightly conical to cylindrical, with sharp tips (Fig. 2D). The apical actine is very thin and shorter than the basal ones. It is cylindrical and blunt, covered by abundant tiny spines (Fig. 2E). Size: 79.1/8.8 $\mu \mathrm{m}$ (basal actine); 41.9/3.2 $\mu \mathrm{m}$ (apical actine).

Diactines. Slightly curved. The tip that protrudes through the surface is lanceolated (Fig. 2F). Trichoxeas are also present on the surface of the tubes. Size: 106.3/4.9 $\mu \mathrm{m}$.

\section{Ecology}

Specimens were collected on a vertical, shaded hard limestone bottom.

\section{Remarks}

Klautau et al. (2013) proposed to transfer this species to the genus Ascaltis based mainly on morphological, but also on molecular data. Although the type species of this genus (A. lamarcki Haeckel, 1870) was not included in the molecular dataset, $A$. reticulum did not group with any of the included genera (Fig. 16). Besides, morphologically it is more similar to Ascaltis than to any other genus. Therefore, although the classification of $A$. reticulum in the genus Ascaltis must still be verified regarding the type species of the 
genus, it was morphologically and molecularly proved that it cannot be included in the genus Clathrina. Hence, we keep the proposition of Klautau et al. (2013) and name this species A. reticulum.

This is the first time that spines were observed on the apical actine of the tetractines of $A$. reticulum. For that reason, we examined the neotype of this species and detected spines as well. They are abundant and very small. We also observed a great variation in the size of the diactines, which are much larger in the neotype (102.0-212.2 ( \pm 54.1$)-306.0 / 14.3( \pm 5.1) \mu \mathrm{m})$.

Genus Ascandra Haeckel, 1872

Ascandra spalatensis sp. nov. urn:1sid:zoobank.org:act:A5DC68F2-D856-4492-AF50-E5F6A1A7FD8A

Fig. 3; Table 3

\section{Etymology}

From the type locality. Spalato is an Italian name for Split, the largest city of the Dalmatian region.
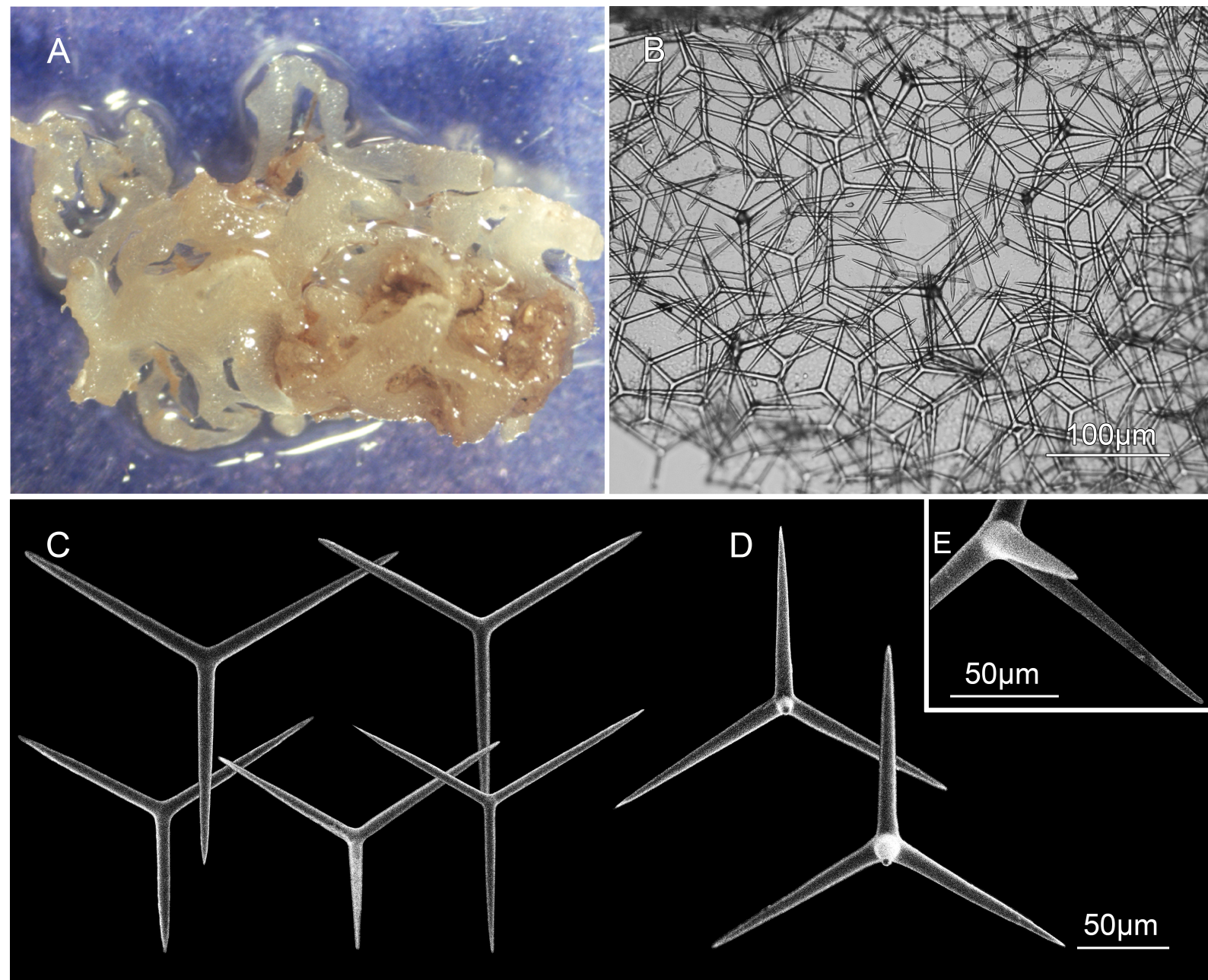

Fig. 3. Ascandra spalatensis sp. nov., holotype (PMR $17806=$ UFRJPOR 7540). A. Specimen in ethanol. B. Tangential section. C. Triactines. D. Tetractines. E. Apical actine of a tetractine. 
Table 3. Spicule measurements of the holotype of Ascandra spalatensis sp. nov. (PMR-17806 = UFRJPOR 7540).

\begin{tabular}{lcccccccccc}
\hline & \multicolumn{1}{c}{ length $(\boldsymbol{\mu m})$} & \multicolumn{1}{c}{ width $(\boldsymbol{\mu m})$} \\
\hline Spicule & Actine & $\min$ & mean & sd & $\max$ & $\min$ & mean & $\mathrm{sd}$ & $\max$ & $\mathrm{n}$ \\
Triactine & Basal & 43.2 & $\underline{90.5}$ & 17.2 & 113.4 & 6.8 & $\underline{8.0}$ & 0.8 & 9.5 & 20 \\
Tetractine & Basal & 51.3 & $\underline{99.4}$ & 16.9 & 135.0 & 8.1 & $\underline{12.0}$ & 1.6 & 14.9 & 21 \\
& Apical & 72.9 & $\underline{\mathbf{7 4 . 3}}$ & 1.9 & 75.6 & 10.8 & $\underline{10.8}$ & 0 & 10.8 & 2 \\
\hline
\end{tabular}

\section{Material examined}

Holotype

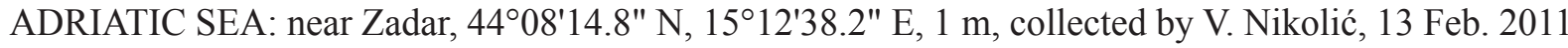
(PMR-17806 = UFRJPOR 7540, in ethanol).

\section{Colour}

White in ethanol.

\section{Description}

The sponge is small, only a fragment, but it is possible to recognise large and loosely anastomosed tubes, typical of Ascandra (Fig. 3A). The skeleton is composed of triactines and a few tetractines (Fig. 3B).

\section{Spicules (Table 3)}

TRIACtinEs. Regular (equiangular and equiradiate), but there are also subregular (sagittal) spicules. Actines are cylindrical to slightly conical with sharp tips (Fig. 3C). Size: 90.5/8.0 $\mu \mathrm{m}$.

TEtRACtines. Regular (equiangular and equiradiate) or subregular. Actines are strongly conical with sharp tips (Fig. 3D). The apical actine is shorter than the basal ones, thick, conical, sharp and smooth (Fig. 3E). Size (basal actine): 99.4/12.0 $\mu \mathrm{m} ; 74.3 / 10.8 \mu \mathrm{m}$ (apical actine).

\section{Ecology}

The specimen was collected on a shaded, vertical hard bottom.

\section{Remarks}

The genus Ascandra is so far composed of 13 species: A. falcata Haeckel, 1872; A. ascandroides (Borojević, 1971); A. atlantica (Thacker, 1908); A. biscayae (Borojević \& Boury-Esnault, 1987); A. brandtae (Rapp et al., 2013); A. contorta (Bowerbank, 1866); A. corallicola (Rapp, 2006); A. crewsi Van Soest \& De Voogd, 2015; A. densa Haeckel, 1872; A. kakaban Van Soest \& De Voogd, 2015; A. loculosa (Dendy, 1891); A. minchini Borojević, 1966; and A. sertularia Haeckel, 1872.

In 2013, Klautau et al. proposed the following diagnosis for Ascandra: "Calcinea with loosely anastomosed tubes. Tubes are free, at least in the apical region. The skeleton contains regular (equiangular and equiradiate) or sagittal triactines and tetractines. Tetractines are the main spicules, occurring at least in the same proportion as the triactines. They have very thin (needle-like) apical actines. Diactines may be added. Asconoid aquiferous system."

After the discovery of $A$. spalatensis sp. nov., we propose here an emendation to this diagnosis: "Calcinea with loosely anastomosed tubes. Tubes are free, at least in the apical region. The skeleton contains regular (equiangular and equiradiate) or sagittal triactines and tetractines. The apical actine is very thin (needle-like) or very thick at the base. Diactines may be added. Asconoid aquiferous system." 
Our new species is a very typical Ascandra, with apically free, loosely anastomosed tubes. Its skeleton is very similar to that of $A$. ascandroides, i.e., composed of triactines and tetractines, the former being more abundant than the latter and the apical actine of the tetractines being very thick at the base. Both species, however, can be differentiated by the size of the spicules (A. ascandroides - triactines: $90-130( \pm 20)-163$ /13( \pm 2$)$; small tetractines: 107.5-164.5 $( \pm 35)-260 / 16.5( \pm 2.8)$; large tetractines: 193.8-313.1 $( \pm 63.2)$ 418.2/39.8( \pm 8.2$)$ ). Moreover, A. ascandroides has two categories of tetractines and A. spalatensis sp. nov. only one. In our ITS tree (Fig. 16) this species is well nested within the Ascandra clade, with high support values in both, Bayesian and ML analyses.

\section{Genus Borojevia Klautau et al., 2013}

Borojevia cerebrum (Haeckel, 1872)

Fig. 4; Table 4

Ascaltis cerebrum Haeckel, 1872: 54.

Auloplegma cerebrum Haeckel, 1872: 55.

Ascaltis decipiens Haeckel, 1872: 55.

Ascaltis gyrosa Haeckel, 1872: 55.
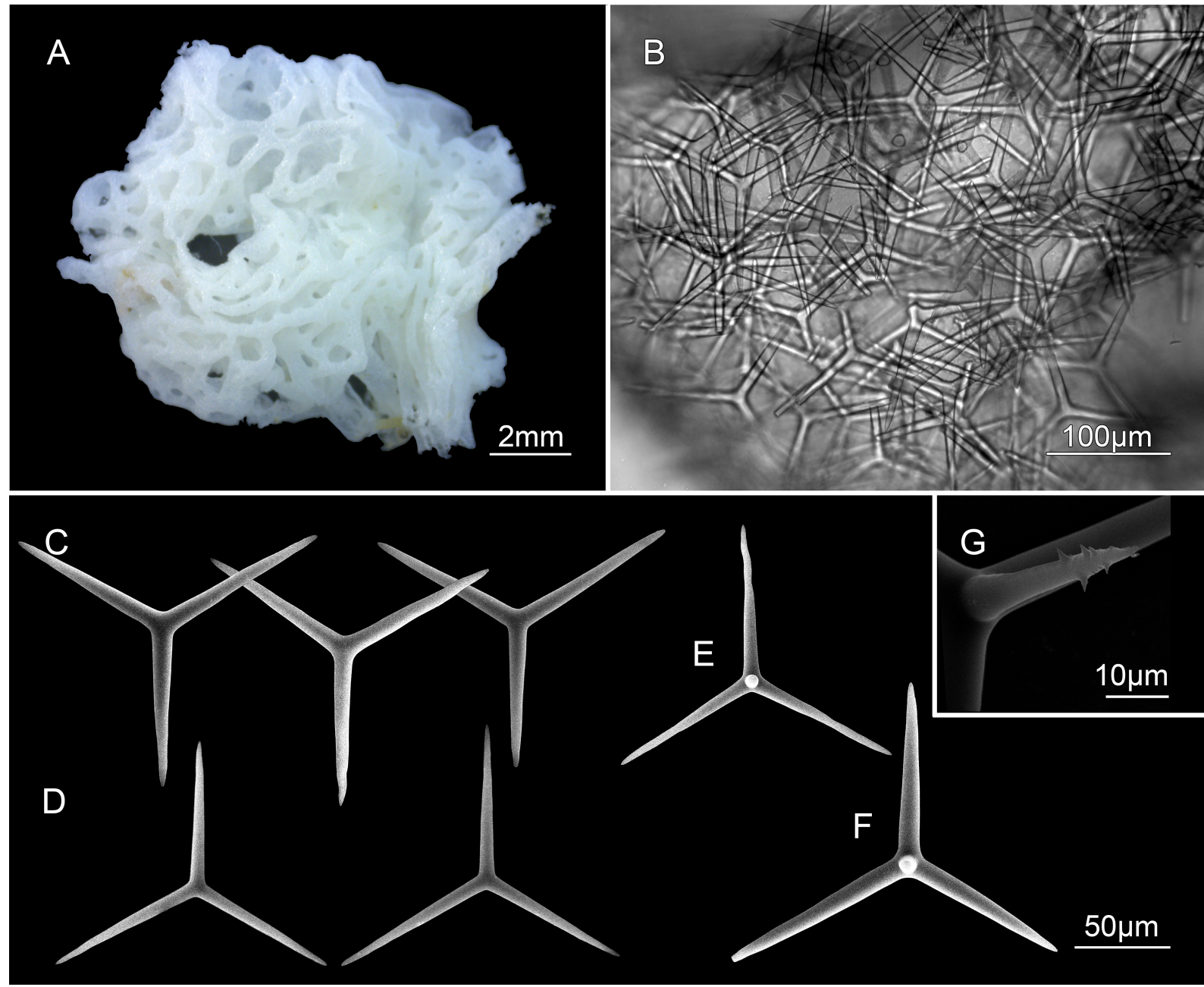

Fig. 4. Borojevia cerebrum (IRB-CLB33 = UFRJPOR 7539). A. Specimen in ethanol. B. Tangential section. C. Tripods. D. Triactines. E. Small tetractine. F. Large tetractine. G. Apical actine of a tetractine ornamented with spines. 
KLAUTAU M. et al., Adriatic calcarean sponges (Porifera, Calcarea)

Table 4. Spicule measurements of Borojevia cerebrum (IRB-CLB33 = UFRJPOR 7539).

\begin{tabular}{llccccccccc}
\hline & & \multicolumn{9}{c}{ length $(\boldsymbol{\mu m})$} \\
\hline Spicule & Actine & min & mean & sd & $\max$ & $\min$ & mean & sd & $\max$ & $\mathrm{n}$ \\
Tripod & Basal & 72.9 & $\underline{91.8}$ & 9.9 & 108.0 & 8.1 & $\underline{11.2}$ & 1.5 & 13.5 & 20 \\
Triactine & Basal & 54.0 & $\underline{\underline{84.6}}$ & 11.8 & 105.3 & 5.4 & $\underline{8.9}$ & 1.3 & 10.8 & 20 \\
Tetractine & Basal & 64.8 & $\underline{81.9}$ & 10.0 & 105.3 & 6.8 & $\underline{8.5}$ & 1.5 & 12.2 & 20 \\
& Apical & 35.1 & $\underline{46.8}$ & 8.4 & 64.8 & 5.4 & $\underline{5.4}$ & 0.0 & 5.4 & 20 \\
\hline
\end{tabular}

Ascetta cerebrum - Bianco 1888: 386. — Lendenfeld 1891: 206 - Bidder 1891: 628.

Clathrina cerebrum - Minchin 1896: 359. — Borojević 1967: 192. — Borojević et al. 1968: 31. — Solé-

Cava et al. 1991: 382. — Klautau \& Valentine 2003: 14. — Longo \& Pronzato 2011: 219.

Leucosolenia cerebrum - Kirk 1896: 207. — Breitfuss 1897b: 210; 1898c: 172; 1935: 8. — Dendy \& Row 1913: 724. — Burton 1933: 236; 1963: 186. — Topsent 1934: 7; 1936: 17.

Leucosolenia decipiens - Dendy \& Row 1913: 725. — Ferrer 1918: 9.— Breitfuss 1935: 9. — Tanita 1943: 78.

Borojevia cerebrum - Klautau et al. 2013: 452.

non Clathrina cerebrum - Borojević 1971: 526 (non Clathrina cerebrum).

\section{Type specimen}

ADRIATIC SEA: Lesina (Croatian: Island of Hvar), Haeckel collection (PMJ-Inv. Nr. Porif. 156, syntype/ethanol).

\section{Material examined}

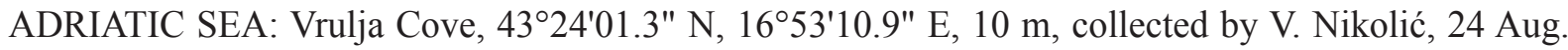
2011 (PMR-17808; IRB-CLB33 = UFRJPOR 7539).

\section{Colour}

Light yellow in life and in ethanol.

\section{Description}

Cormus is composed of regular and tightly anastomosed tubes (Fig. 4A). Large water-collecting tubes are present. The skeleton consists of triactines, a few tetractines and tripods, which in fact are large triactines. It has no special organisation (Fig. 4B).

\section{Spicules (Table 4)}

TRIPODS. Regular (equiangular and equiradiate). The tripods of analysed specimens are more similar to large triactines than to true tripods with an elevated centre. Actines are conical, straight, with sharp tips (Fig. 4C). Size: 91.8/11.2 $\mu \mathrm{m}$.

TRIACTINES. Regular (equiangular and equiradiate). Actines are slightly conical to conical, straight, with sharp tips. Sometimes they are slightly undulated near the tips (Fig. 4D). Size: 84.6/8.9 $\mu \mathrm{m}$.

Tetractines. Regular (equiangular and equiradiate). Actines are slightly conical to conical, straight, with sharp tips. Sometimes they are slightly undulated near the tips. It is possible to recognise two types of tetractines: small (Fig. 4E) and large (Fig. 4F). Large tetractines are the same size as tripods. The apical actine of the tetractines is shorter than the basal ones, slightly conical, sharp and frequently curved only at the tip. It is ornamented with few ( $c a$. six) spines, which are large, conical and cover only the last third of the apical actine. (Fig. 4G). Size: 81.9/8.5 $\mu \mathrm{m}$ (basal actine); 46.8/5.4 $\mu \mathrm{m}$ (apical actine). 


\section{Ecology}

The specimen was collected on a semi-vertical hard limestone bottom.

\section{Remarks}

Similar to other species of Borojevia, B. cerebrum has thin, regular and tightly anastomosed tubes forming the cormus. The oscula are present at the end of water-collecting tubes. The skeleton is composed of tripods (with the characteristic elevated centre or similar to large triactines), triactines and tetractines. Individuals of $B$. cerebrum always have spines on the apical actine of their tetractines; however, in the same individual some tetractines may be smooth. In B. cerebrum, the spines are not very abundant; they are large and scattered, only near the tip of the apical actine. The Adriatic and Mediterranean specimens of B. cerebrum formed a well supported clade in the ITS tree (Fig. 16), separated from the clade comprising B. brasiliensis (Solé-Cava, Klautau, Boury-Esnault, Borojević \& Thorpe, 1991).

Borojevia cerebrum is the type species of the genus. Its type locality is Lesina (Island of Hvar) and it commonly occurs in the Mediterranean and the Adriatic Sea. The type specimen of B. cerebrum (PMJ-Inv. Nr. Porif. 156) is not very well preserved (Klautau \& Valentine 2003); thus, we got a great opportunity to redescribe this species from near its type locality.

Analyses of other individuals of B. cerebrum from several sites in the Adriatic and Mediterranean Seas verify that the shape of the tripods is very variable. It varies from the characteristic shape of tripods, with stout actines and elevated centre, to only large triactines. This kind of variability may be assigned to polymorphism or plasticity. Indeed, Haeckel (1872) proposed two varieties of B. cerebrum (as Ascaltis cerebrum), based on the presence of either characteristic tripods or large triactines. The first variety he called B. cerebrum var. gyrosa, while the other one he considered B. cerebrum var. decipiens. Dendy \& Row (1913) elevated B. cerebrum var. decipiens to species level (as Leucosolenia decipiens) and kept B. cerebrum (as L. cerebrum) as a valid species. The variety gyrosa had not been oficially elevated to the status of species; however, it was mentioned as Ascaltis gyrosa in a synonym list of $B$. cerebrum made by Burton (1963: 186).

Considering that both varieties were proposed only to differentiate specimens with characteristic tripods from those with only large triactines and that we found this morphological variation inside individuals and among specimens placed within the same species, we propose here the synonymisation of $B$. decipiens with $B$. cerebrum.

Borojevia croatica sp. nov. urn:1sid:zoobank.org:act:A9F84084-E033-43A9-AB71-83670090C7C1

Fig. 5; Table 5

\section{Etymology}

From the type locality.

\section{Material examined}

Holotype

ADRIATIC SEA: near the Island of Čiovo, $43^{\circ} 28^{\prime} 58.5^{\prime \prime} \mathrm{N}, 16^{\circ} 21^{\prime} 25.6^{\prime \prime} \mathrm{E}, 5 \mathrm{~m}$, collected by B. Pleše and V. Nikolić, 5 Nov. 2010 (PMR-13740 = UFRJPOR 6864, in ethanol).

\section{Paratype}

ADRIATIC SEA: same data as holotype (PMR-13741 = UFRJPOR 6865, in ethanol). 


\section{Colour}

White in life and in ethanol.

\section{Description}

Cormus composed of regular and tightly anastomosed tubes (Fig. 5A). Water-collecting tubes are present and form a single apical osculum. The skeleton is composed of tripods, triactines and rare tetractines. It has no special organisation (Fig. 5B).

\section{Spicules (Table 5)}

TRIPODS. Regular (equiangular and equiradiate) or sagittal. Some of them have an elevated centre, but most appear like large regular triactines. Actines are conical, straight, with sharp tips (Fig. 5C). Size: 102.6/11.9 $\mu \mathrm{m}$.

TRIACTINES. Regular (equiangular and equiradiate). Actines are conical, straight, with sharp tips (Fig. 5D). Size: $66.6 / 7.5 \mu \mathrm{m}$.
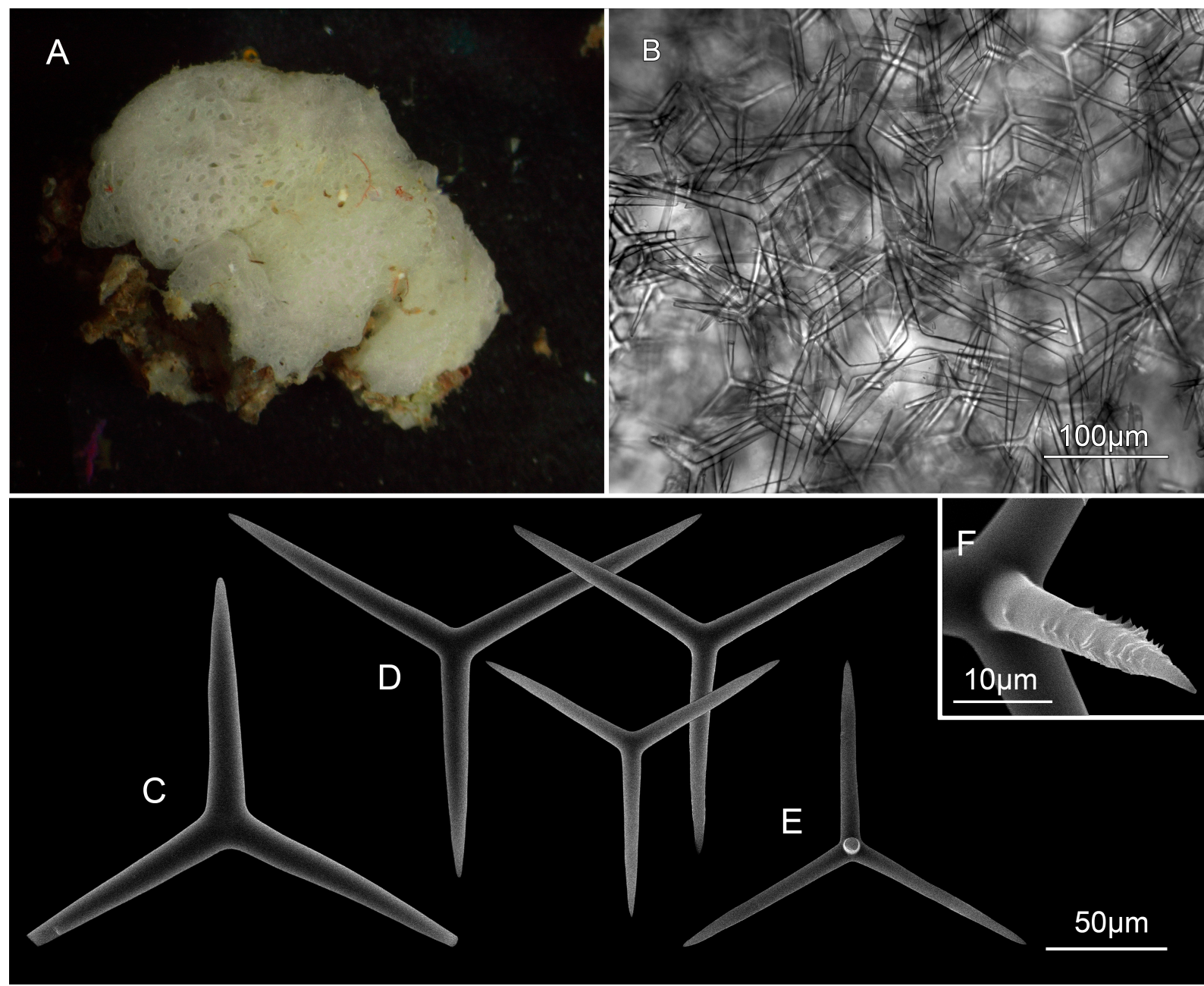

Fig. 5. Borojevia croatica sp. nov., holotype (PMR $13740=$ UFRJPOR 6864). A. Specimen in situ B. Tangential section. C. Tripod. D. Triactines. E. Tetractine. F. Apical actine of a tetractine ornamented with spines. 
Table 5. Spicule measurements of Borojevia croatica sp. nov. Holotype (PMR-13740 = UFRJPOR 6864) and paratype (PMR-13741 = UFRJPOR 6865).

\begin{tabular}{|c|c|c|c|c|c|c|c|c|c|c|}
\hline & & \multicolumn{4}{|c|}{ length $(\mu \mathrm{m})$} & \multicolumn{4}{|c|}{ width $(\mu \mathrm{m})$} & \\
\hline & & $\min$ & mean & $\mathrm{sd}$ & $\max$ & $\min$ & mean & $\mathrm{sd}$ & $\max$ & $\mathrm{n}$ \\
\hline Holotype & & & & & & & & & & \\
\hline Tripod & Basal & 85.0 & $\underline{102.6}$ & 10.0 & 115.0 & 10.0 & $\underline{11.9}$ & 1.5 & 15.0 & 20 \\
\hline Triactine & Basal & 57.5 & $\underline{66.6}$ & 6.7 & 82.5 & 7.5 & $\underline{7.5}$ & 0.0 & 7.5 & 20 \\
\hline Tetractine & Basal & 60.0 & $\underline{70.0}$ & 6.3 & 77.5 & 7.5 & $\underline{8.3}$ & 1.2 & 11.3 & 10 \\
\hline Paratype & Apical & - & $\underline{20}$ & - & - & - & $\underline{5.0}$ & - & - & 1 \\
\hline Tripod & Basal & 50.0 & 78.8 & 19.1 & 115.0 & 7.5 & 10.8 & 1.8 & 15.0 & 13 \\
\hline Triactine & Basal & 50.0 & $\underline{66.1}$ & 8.6 & 80.0 & 7.5 & 7.8 & 0.7 & 10.0 & 20 \\
\hline Tetractine & Basal & 62.5 & 71.0 & 5.1 & 80.0 & 7.5 & 8.3 & 1.1 & 10.0 & 20 \\
\hline
\end{tabular}

Tetractines. Regular (equiangular and equiradiate). Actines are conical, straight, with sharp tips (Fig. 5E). The apical actine has very short and abundant spines organised in parallel rows. These spines cover the first $2 / 3$ of the apical actine (Fig. 5F). Size: 70.0/8.3 $\mu \mathrm{m}$ (basal actine); 20.0/5.0 $\mu \mathrm{m}$ (apical actine).

\section{Ecology}

Specimens were collected on a shaded, vertical, hard limestone bottom.

\section{Remarks}

The genus Borojevia is currently composed of five species: B. aspina (Klautau, Solé-Cava \& Borojević, 1994), B. brasiliensis, B. cerebrum, B. paracerebrum (Austin, 1996) and B. tetrapodifera (Klautau \& Valentine, 2003). All of them show a very well defined cormus, with regular and tightly anastomosed tubes and water-collecting tubes. The skeleton is always composed of tripods, triactines and tetractines with spines on the apical actines. Tetrapods may also be present (B. tetrapodifera). The sixth species of the genus, $B$. croatica sp. nov., is closer to $B$. cf. aspina in our ITS tree (Fig. 16). Both species have short spines; however, $B$. croatica sp. nov. has numerous spines, while in $B$. cf. aspina there are few.

Given that $B$. cerebrum is also present in the Adriatic Sea, the best way to differentiate it from $B$. croatica sp. nov. is by the shape and location of spines. They are shorter, more abundant and distributed along most of the actine length in $B$. croatica sp. nov., and larger, fewer and scattered only near the tip of the apical actine in $B$. cerebrum.

Genus Clathrina Gray, 1867

Clathrina conifera Klautau \& Borojević, 2001

Fig. 6; Table 6

Clathrina conifera Klautau \& Borojević, 2001: 404.

Clathrina primordialis (non C. primordialis (Haeckel, 1872)) - Borojević 1971: 527. — Borojević \& Peixinho 1976: 992. — Mothes de Moraes 1985: 228. — Klautau et al. 1994: 372. — Muricy \& Silva 1999: 160 . 
Clathrina conifera - Klautau \& Valentine 2003: 18. - Monteiro \& Muricy 2004: 682. — Muricy \& Hajdu 2006: 86. — Lanna et al. 2007: 1554. — Custódio \& Hajdu 2011: 4. — Muricy et al. 2011: 33. - Bouzon et al. 2012: 42.

\section{Material examined}

\section{Holotype}

BRAZIL: Arraial do Cabo, Rio de Janeiro (BMNH 1999.9.16.19, in ethanol).

\section{Other material}

ADRIATIC SEA: near the Island of Lokrum, 42 $37^{\prime} 55.6^{\prime \prime} \mathrm{N}, 18^{\circ} 06^{\prime} 49.4^{\prime \prime} \mathrm{E}$; 1-3 m deep, collected by V. Nikolić, 8 Oct. 2010 (PMR-13738 = UFRJPOR 6869); near Dubrovnik, 42³8'26.5" N, 1806'14.2" E; $1 \mathrm{~m}$, collected by V. Nikolić, 24 Sep. 2011 (PMR-17807, IRB-S2 = UFRJPOR 7541, IRB-S3 = UFRJPOR 7542).

\section{Colour}

White in life and white or brown in ethanol.
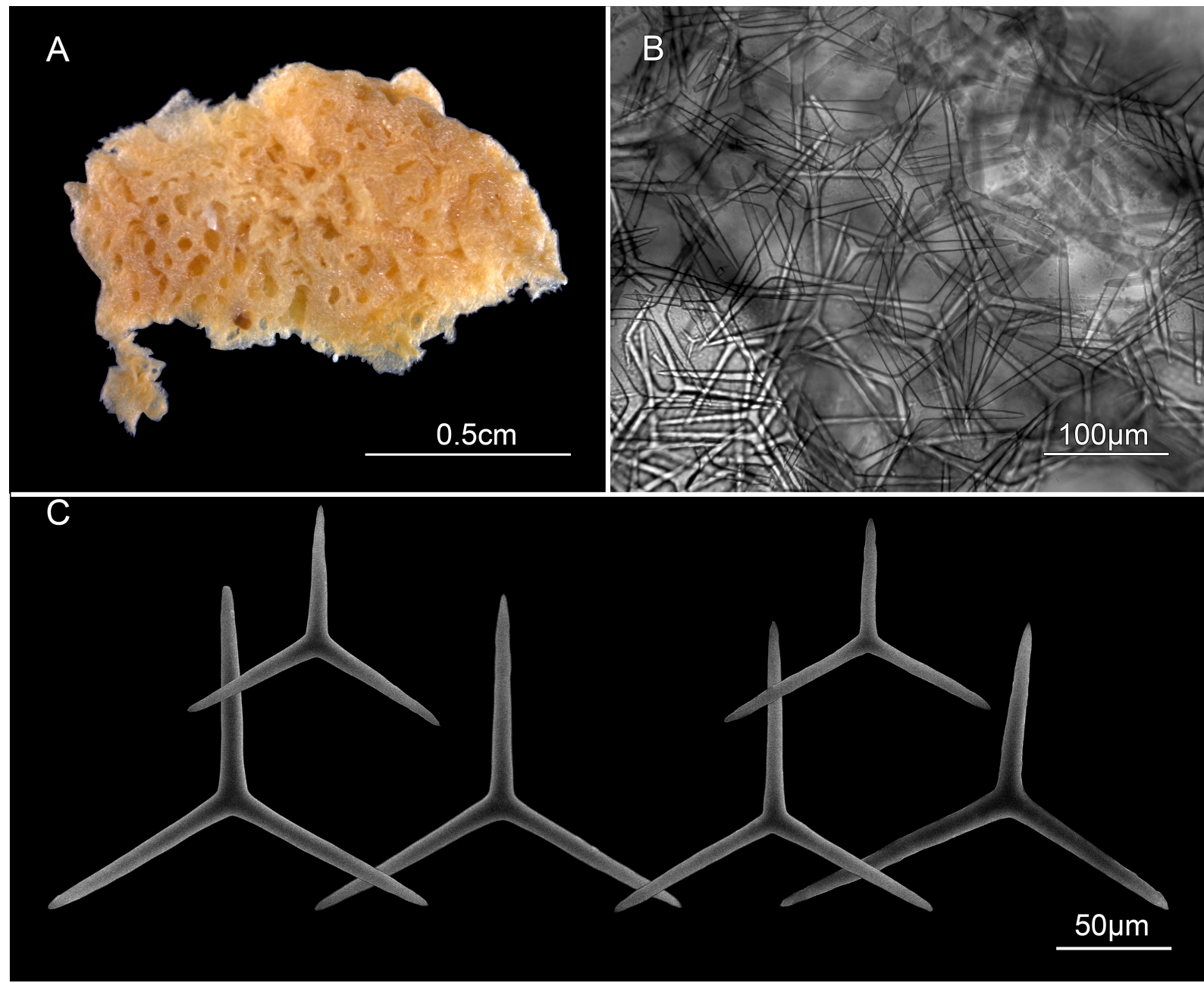

Fig. 6. Clathrina conifera (PMR $13738=$ UFRJPOR 6869). A. Specimen in ethanol. B. Tangential section. C. Triactines with variable sizes and shapes. 
Table 6. Spicule measurements (triactines) of Clathrina conifera Klautau \& Borojević, 2001 (PMR13738 = UFRJPOR 6869; IRB-S2 = UFRJPOR 7541; IRB-S3 = UFRJPOR 7542).

\begin{tabular}{lccccccccc}
\hline & \multicolumn{4}{c}{ length $(\boldsymbol{\mu m})$} & \multicolumn{7}{c}{ width $(\boldsymbol{\mu m})$} \\
\hline & min & mean & $\mathrm{sd}$ & $\max$ & $\min$ & mean & $\mathrm{sd}$ & $\max$ & $\mathrm{n}$ \\
PMR-13738 = UFRJPOR6869 & 57.5 & $\underline{88.5}$ & 11.8 & 122.5 & 7.5 & $\underline{10.2}$ & 1.6 & 15.0 & 30 \\
IRB-S2 = UFRJPOR7541 & 59.4 & $\underline{86.3}$ & 9.6 & 97.2 & 8.1 & $\underline{9.5}$ & 1.4 & 10.8 & 20 \\
IRB-S3 = UFRJPOR7542 & 64.8 & $\underline{82.5}$ & 8.9 & 102.6 & 6.8 & $\underline{8.8}$ & 1.3 & 10.8 & 20 \\
\hline
\end{tabular}

\section{Description}

Cormus composed of irregular and loosely anastomosed tubes (Fig. 6A). Water-collecting tubes are not present. The skeleton consists of triactines without organisation (Fig. 6B).

\section{Spicules (Table 6)}

Triactines. Regular (equiangular and equiradiate). Their size is very variable. Actines are slightly conical to conical, straight, with blunt tips. Sometimes they are slightly undulated near the tips (Fig. 6C). Size: $88.5 / 10.2 \mu \mathrm{m}$.

\section{Ecology}

Specimens were collected on a semi-shaded, vertical hard limestone bottom under overhangs. They were often found in association with the macroalga Ellisolandia elongata (J. Ellis \& Solander, 1786).

\section{Remarks}

Until now, this species was considered endemic to Brazil (Borojević 1971; Mothes de Moraes 1985; Klautau et al. 1994; Monteiro \& Muricy 2004; Muricy \& Hajdu 2006; Lanna et al. 2007). Originally, it was identified as C. primordialis (Haeckel, 1872) (Borojević 1971; Mothes de Moraes 1985; Klautau et al. 1994). However, considering differences in the size of the actines (holotype of $C$. conifera: 62.5-77.3( \pm 9.3$)-97.5 / 9( \pm 1.0) \mu \mathrm{m}$; Haeckel measurements of $C$. primordialis: $100-150 / 8-12 \mu \mathrm{m})$, it was described as a new species: $C$. conifera. In the present work, we confirmed by morphological and molecular analyses (Fig. 16) that $C$. conifera is really distinct from C. primordialis and that it occurs in the Adriatic Sea.

Clathrina primordialis (Haeckel, 1872)

Fig. 7; Table 7

?Grantia pulchra Schmidt, 1862:18.

?Leucosolenia pulchra Schmidt, 1866: 8.

Prosycum primordiale Haeckel, 1870: 237.

Olynthus simplex Haeckel, 1870: 237.

Nardoa arabica Miklucho in Haeckel, 1872: 16.

Ascetta primordialis Haeckel, 1872: 16.

Olynthus primordialis Haeckel, 1872: 16.

Clistolynthus primordialis Haeckel, 1872: 16.

Soleniscus primordialis Haeckel, 1872: 16.

Ascometra primordialis Haeckel, 1872: 16.

?Ascaltis primordialis Haeckel, 1872: 17.

?Ascortis primordialis Haeckel, 1872: 17. 
?Ascandra primordialis Haeckel, 1872: 18.

Ascetta primordialis Lendenfeld, 1885: 897.

L. primordialis var. apicalis Brøndsted, 1931: 9.

Clathrina cf. hondurensis - Imesek et al. 2014: 25.

Ascetta primordialis - Lendenfeld 1891: 11. - Arnesen 1901: 12.

Clathrina primordialis - Carter 1886: 510. — Minchin 1896: 359. — Jenkin 1908: 436. — Row 1909: 184. - Klautau \& Valentine 2003: 32. — Longo \& Pronzato 2011: 229.

Leucosolenia primordialis - Lackschewitsch 1886: 299. — Breitfuss 1898a: 12; 1898b: 91. — Dendy \& Row 1913: 726. — Ferrer Hernández 1918: 10. — Burton 1926: 71; 1963: 197. — Row \& Hôzawa 1931: 736. —Breitfuss 1932: 242; 1935: 12. — Arndt 1941: 45. — Tanita 1942: 73; 1943: 370.

non C. primordialis - Borojević 1971: 527. — Borojević \& Peixinho 1976: 992. — Mothes de Moraes 1985: 228. — Klautau et al. 1994: 372. — Muricy \& Silva 1999: 160.
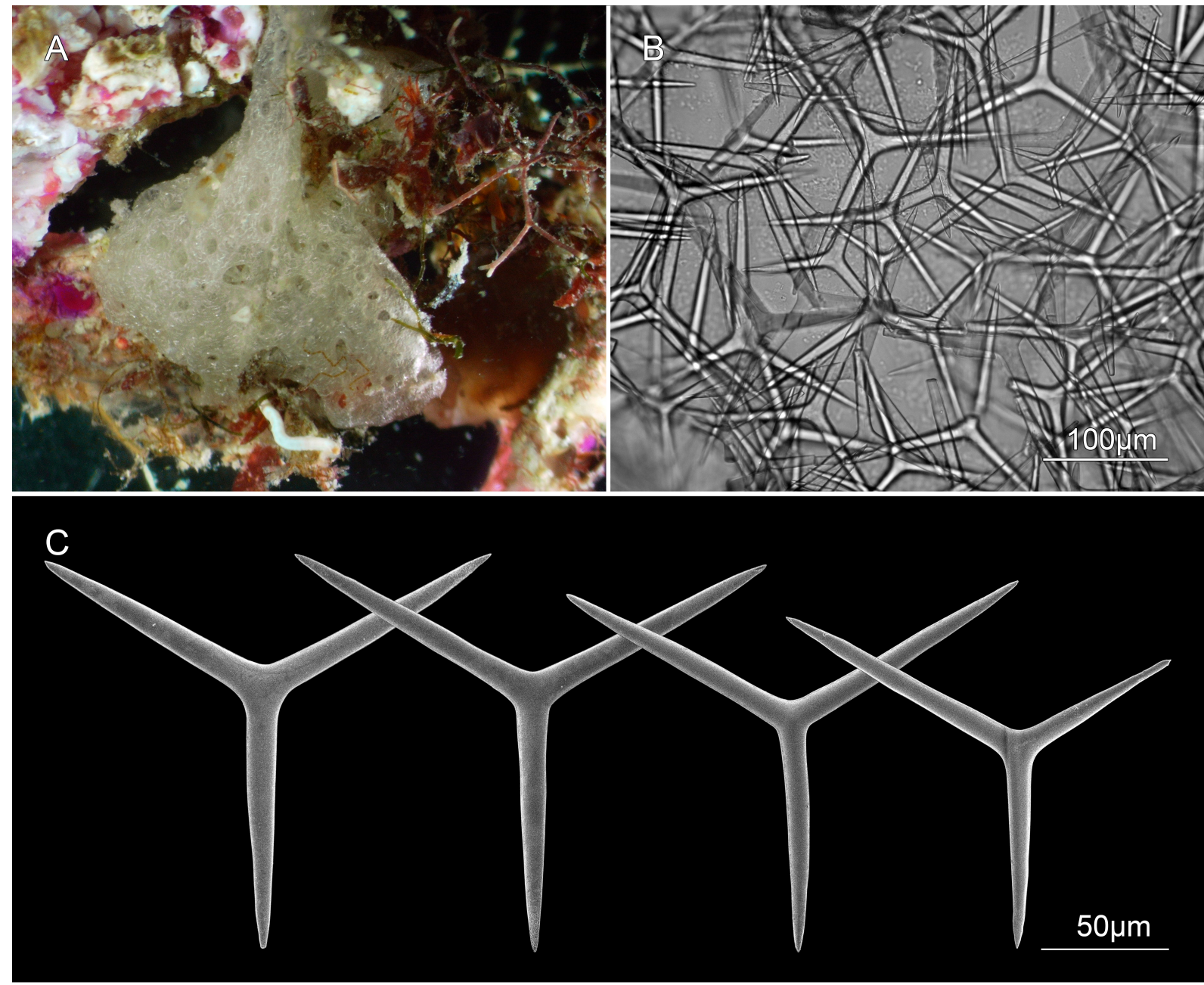

Fig. 7. Clathrina primordialis (IRB-CLB3 = UFRJPOR 6863). A. Specimen in situ. B. Tangential section. C. Triactines with variable sizes and shapes. 
Table 7. Spicule (triactine) measurements of Clathrina primordialis (Haeckel, 1872). IRB-CLB3 = UFRJPOR 6863 (present work); PMJ 154 (suggested lectotype); PMR-14305 (C. cf. hondurensis in Imešek et al. 2014); BMNH 1938.3.28.4 (holotype of C. hondurensis).

\begin{tabular}{lccccccccc}
\hline & \multicolumn{3}{c}{ length $(\boldsymbol{\mu m})$} & \multicolumn{1}{c}{ width $(\boldsymbol{\mu m})$} \\
\hline & $\min$ & mean & $\mathrm{sd}$ & $\max$ & $\min$ & mean & $\mathrm{sd}$ & $\max$ & $\mathrm{n}$ \\
IRB-CLB3 = UFRJPOR 6863 & 47.5 & $\underline{121.5}$ & 27.9 & 157.5 & 7.5 & $\underline{12.2}$ & 2.4 & 15.0 & 20 \\
Haecke1, 1872 & 100.0 & - & - & 150.0 & 8.0 & - & - & 12.0 & - \\
PMJ154 (lectotype) & 97.5 & $\underline{134.0}$ & 16.3 & 157.5 & 10.0 & $\underline{13.0}$ & 2.2 & 17.5 & 30 \\
PMR-14305 & 101.8 & $\underline{128.0}$ & 9.6 & 151.5 & 13.3 & $\underline{15.2}$ & 1.3 & 19.0 & 33 \\
BMNH 1938.3.28.4 & 105.6 & $\underline{133.4}$ & 17.0 & 156.0 & 12.0 & $\underline{15.6}$ & 1.7 & 19.2 & 20 \\
\hline
\end{tabular}

Material examined

Syntype

ADRIATIC SEA: Lesina (Croatian: Island of Hvar), E. Haeckel collection (PMJ-Inv. Nr. Porif. 154, in ethanol).

\section{Other material}

ADRIATIC SEA: near the Island of Čiovo, Croatia, 4328'58.5" N, 16²1'25.6" E; 5 m, collected by B. Pleše and V. Nikolić, 5 Nov. 2010 (IRB-CLB3 = UFRJPOR 6863).

\section{Colour}

White in life and in ethanol.

\section{Description}

Cormus is formed by large and loosely anastomosed tubes. Water-collecting tubes are absent (Fig. 7A). The skeleton is composed of one category of triactines (Fig. 7B). The size of the spicules is very variable and it is therefore not possible to categorize them.

\section{Spicules (Table 7)}

TRIACTINES. Regular (equiangular and equiradiate). Actines are conical to slightly conical with sharp tips (Fig. 7C). Their size is very variable. Size: $121.5 / 12.2 \mu \mathrm{m}$.

\section{Ecology}

The specimen was collected on a shaded, vertical hard limestone bottom.

\section{Remarks}

Haeckel (1872) assigned the name Ascetta primordialis to a group of different species, and even genera, whose skeleton comprised only triactines, but, unfortunately, did not select a holotype. In 2003, Klautau $\&$ Valentine revised the genus Clathrina and analysed two specimens of $C$. primordialis, one from the Adriatic Sea (PMJ 154) and another one from Naples (ZMB 1306). Both specimens clearly represented different species and the authors suggested the specimen ZMB 1306 was the true C. primordialis, because C. primordialis (originally Prosycum primordiale Haeckel, 1870) was first described from Naples.

However, analysing the present specimen and re-analysing the slides of the specimens PMJ 154 and ZMB 1306 and the catalogue from the ZMB, we now have a different opinion. On the specimen's label and in the catalogue of the ZMB it is not noted that ZMB 1306 is a syntype of C. primordialis. Consequently, Klautau \& Valentine (2003) should not have designated the specimen ZMB 1306 as a lectotype of C. primordialis. On the other hand, the label of the specimen PMJ 154 mentions it is a 
syntype of C. primordialis. Therefore, in our opinion, the specimen PMJ 154 is more reliably a true representative of this species and should be considered the lectotype of C. primordialis.

Considering the morphology of PMJ 154, the specimen IRB-CLB3 = UFRJPOR 6863 represents C. primordialis, as well as the specimen PMR 14305, recently published as $C$. cf. hondurensis Klautau \& Valentine, 2003 (Imešek et al. 2014). The similarities between C. primordialis and C. hondurensis made us ponder on the possibility of synonymy between these two species. However, as we could not obtain DNA sequences of $C$. hondurensis from the type locality (Honduras) to verify this, we prefer to keep $C$. hondurensis as a valid species restricted to the Caribbean Sea, until further analyses are done.

Subclass Calcaronea Bidder, 1898

Genus Leucandra Haeckel, 1872

Leucandra falakra sp. nov. urn:Isid:zoobank.org:act:3DEBFC2C-2E7E-4D8E-A7FA-7FE971CFEDB2

Figs 8-9; Table 8

\section{Etymology}

From the Greek falákra ( $\varphi \alpha \lambda \alpha ́ \kappa \rho \alpha)$, meaning bald, for the absence of diactines.

\section{Material examined}

\section{Holotype}

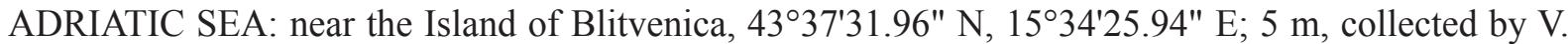
Nikolić, 10 Oct. 2012 (PMR-13748 = UFRJPOR 8349, in ethanol).

\section{Colour}

White in life and in ethanol.

\section{Description}

The sponge is massive and vase-shaped, with one apical osculum without crown. The atrium is central and large. The aquiferous system is leuconoid (Fig. 8A). The sponge surface is smooth, but harsh. The cortical skeleton is composed of small, tangentially arranged triactines. The choanosomal skeleton has no organisation (Fig. 8B). It is composed of two categories of triactines (giant triactines and triactines larger than those of the cortex) (Fig. 8C). There are also tetractines and some triactines surrounding the canals (Fig. 8D). The atrial skeleton is smooth, composed mainly of triactines, with a few tetractines also present (Fig. 8E).

\section{Spicules (Table 8)}

CorticAl triactines. Subregular to sagittal, equiradiate and small. Actines are cylindrical, blunt and curved (Fig. 9A-B). Size: 136.4/11.1 $\mu \mathrm{m}$ (paired actine); 106.0/11.4 $\mu \mathrm{m}$. (unpaired actine).

Choanosomal small triactines. Subregular to sagittal. Actines are conical and sharp (Fig. 9C-D). Size: 214.2/18.3 $\mu \mathrm{m}$ (paired actine); 189.7/19.8 $\mu \mathrm{m}$. (unpaired actine).

Choanosomal giant triactines. Subregular to sagittal, equiradiate. Actines are conical and sharp (Fig. 9E-F). Size: $624.5 / 81.5 \mu \mathrm{m}$.

Choanosomal tetractines. Sagittal. These spicules are present only surrounding the canals. Actines are cylindrical, sharp and curved. The unpaired actine is a little shorter than the paired ones. The apical 

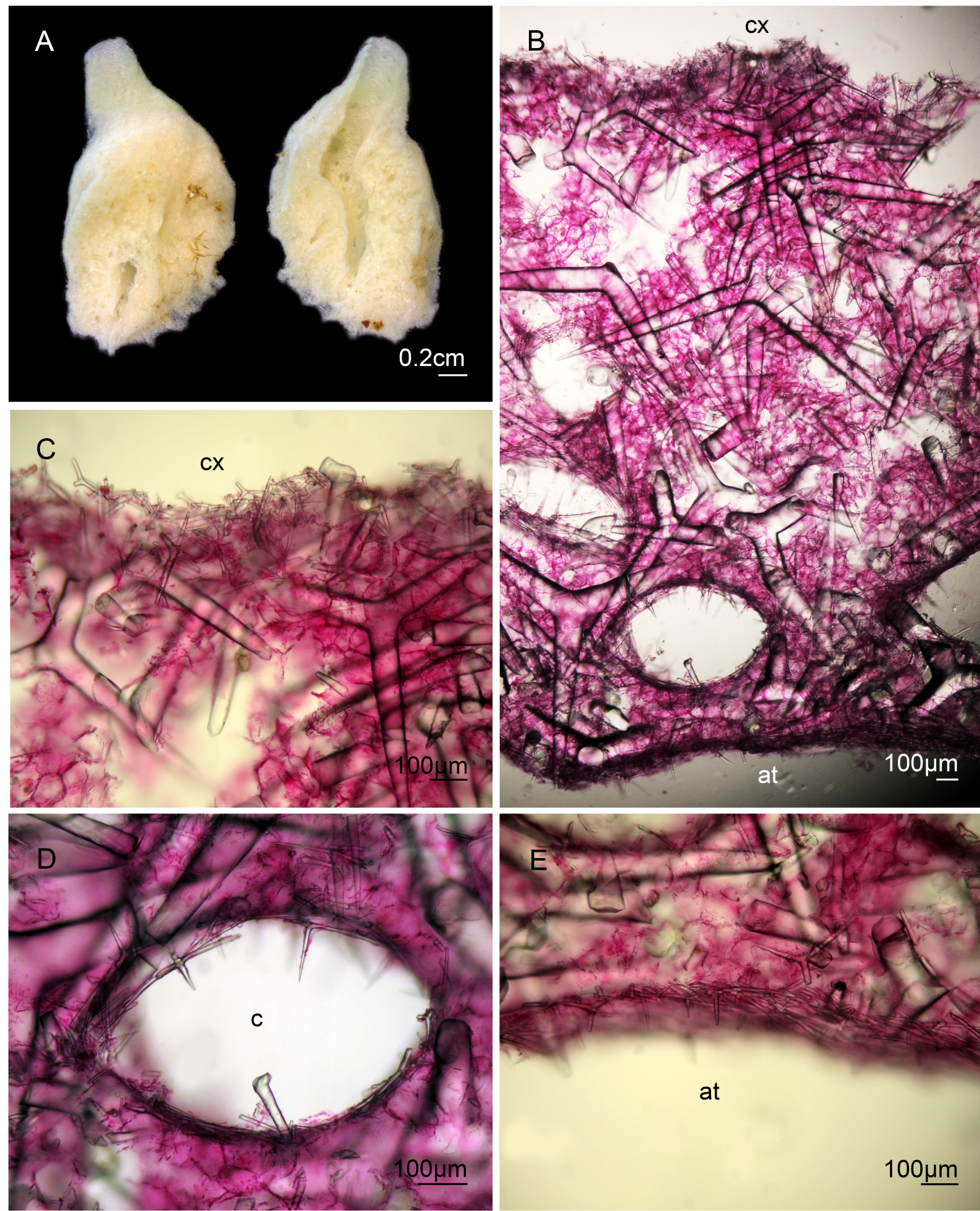

at

$100 \mu \mathrm{m}$

Fig. 8. Leucandra falakra sp. nov., holotype (PMR-13748 = UFRJPOR 8349). A. Specimen in ethanol. B. Cross section. C. Detail of the cortex. D. Detail of a canal in the choanosome. E. Atrial skeleton. Abbreviations: at $=$ atrium; $\mathrm{cx}=$ cortex; $\mathrm{c}=$ canal. 
actine is straight, short, conical and sharp (Fig. 9G-H). Size: 154.0/12.4 $\mu \mathrm{m}$ (paired actine); 143.0/12.4 $\mu \mathrm{m}$ (unpaired actine); 80.6/9.6 $\mu \mathrm{m}$ (apical actine).

Atrial triactines And tetractines. Strongly sagittal. Triactines are the most abundant spicules (Fig. 9I). Actines are cylindrical and blunt. The unpaired actine is shorter than the paired ones. The apical actine of the tetractines is conical, straight, sharp and short. Frequently they are longer and thicker than the apical actine of the choanosomal tetractines (Fig. 9J). Size (triactines): 222.7/15.1 $\mu \mathrm{m}$ (paired actine); 111.2/12.3 $\mu \mathrm{m}$ (unpaired actine). Size (tetractines): 191.4/14.9 $\mu \mathrm{m}$ (paired actine); 92.0/13.1 $\mu \mathrm{m}$ (unpaired actine); $110.3 / 11.9 \mu \mathrm{m}$ (apical actine).

\section{Ecology}

The specimen was collected on a shaded, semi-vertical, hard limestone bottom.

\section{Remarks}

To our knowledge, there are only three described species of Leucandra without diactines and with triactines being the main atrial spicules: L. consolida Tanita, 1943, L. glabra Hôzawa, 1940 and

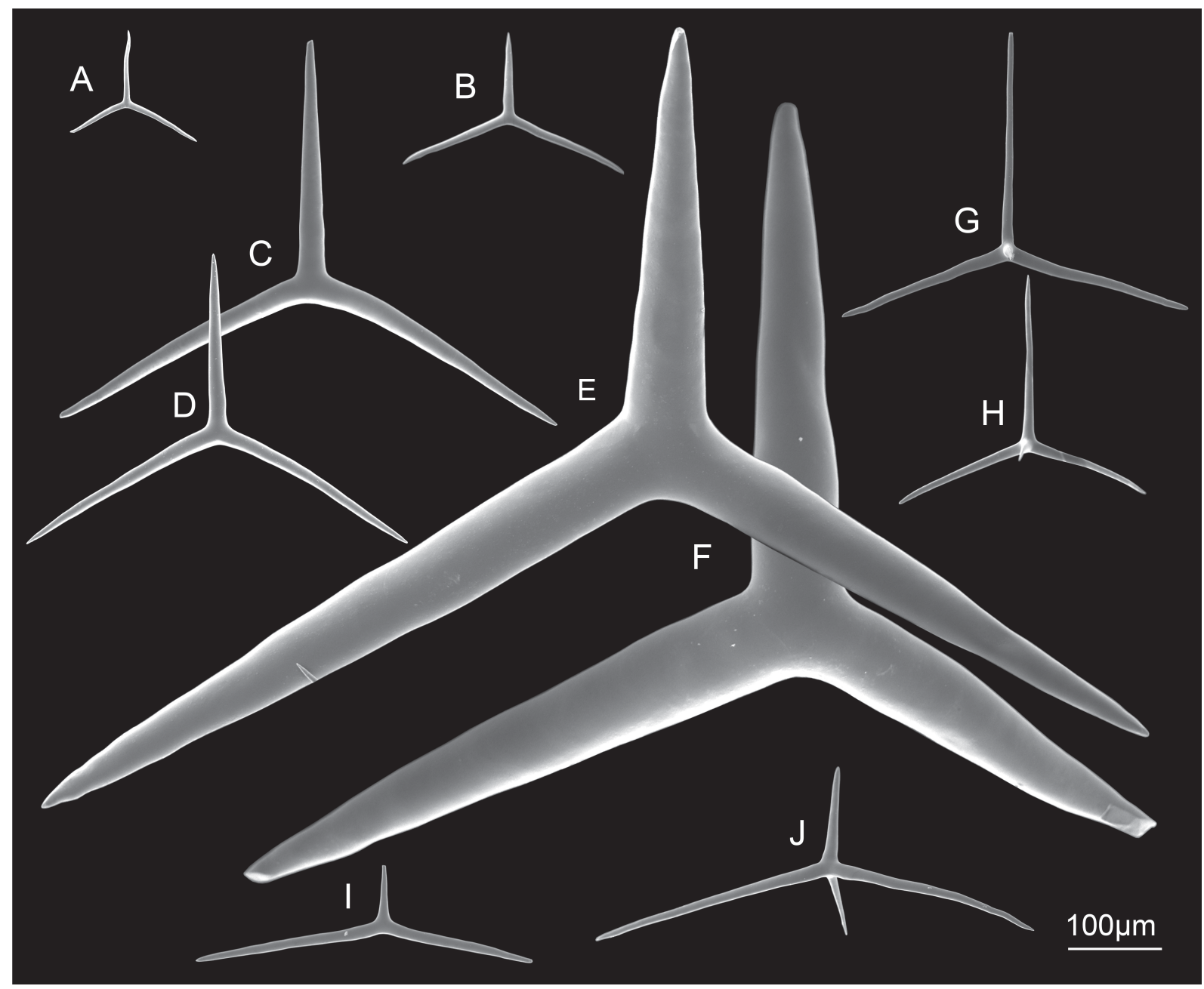

Fig. 9. Leucandra falakra sp. nov., holotype (PMR-13748 = UFRJPOR 8349). A-B. Cortical triactines. C-D. Small choanosomal triactines. E-F. Giant choanosomal triactines. G-H. Tetractines of the canals. I. Atrial triactine. J. Atrial tetractine. Scale bar A-J $=100 \mu \mathrm{m}$. 
Table 8. Spicule measurements of Leucandra falakra sp. nov. (PMR-13748= UFRJPOR 8349).

\begin{tabular}{|c|c|c|c|c|c|c|c|c|c|c|}
\hline & & \multicolumn{4}{|c|}{ length $(\mu \mathrm{m})$} & \multicolumn{4}{|c|}{ width $(\mu \mathrm{m})$} & \multirow[b]{2}{*}{$\mathrm{n}$} \\
\hline \multirow{3}{*}{$\begin{array}{l}\text { Cortical } \\
\text { triactine }\end{array}$} & & $\min$ & mean & $\mathrm{sd}$ & $\max$ & $\min$ & mean & $\mathrm{sd}$ & $\max$ & \\
\hline & Paired & 94.5 & $\underline{136.4}$ & 24.0 & 180.9 & 8.1 & $\underline{11.1}$ & 1.9 & 13.5 & 20 \\
\hline & Unpaired & 70.2 & $\underline{106.0}$ & 18.8 & 143.1 & 8.1 & $\underline{11.4}$ & 2.4 & 16.2 & 20 \\
\hline $\begin{array}{l}\text { Cortical and } \\
\text { choanosomal } \\
\text { triactine }\end{array}$ & & 324.0 & $\underline{624.5}$ & 192.3 & 1047.6 & 48.6 & $\underline{81.5}$ & 20.6 & 118.8 & 23 \\
\hline $\begin{array}{l}\text { Choanosomal } \\
\text { triactine }\end{array}$ & Paired & 162.0 & $\underline{214.2}$ & 39.8 & 288.9 & 13.5 & $\underline{18.3}$ & 4.0 & 27.0 & 20 \\
\hline & Unpaired & 108.0 & 189.7 & 58.9 & 351.0 & 13.5 & $\underline{19.8}$ & 4.1 & 29.7 & 20 \\
\hline $\begin{array}{l}\text { Tetractine } \\
\text { (canals) }\end{array}$ & Paired & 99.9 & $\underline{154.0}$ & 26.4 & 199.8 & 8.1 & $\underline{12.4}$ & 2.4 & 16.2 & 19 \\
\hline & Unpaired & 45.9 & 143.0 & 56.5 & 288.9 & 9.5 & $\underline{12.4}$ & 1.9 & 16.2 & 19 \\
\hline & Apical & 50.0 & $\underline{80.6}$ & 24.4 & 137.5 & 7.5 & 9.6 & 1.5 & 12.5 & 20 \\
\hline Atrial triactine & Paired & 140.4 & 222.7 & 33.7 & 294.3 & 9.5 & $\underline{15.1}$ & 2.5 & 20.3 & 30 \\
\hline & Unpaired & 78.3 & $\underline{111.2}$ & 24.4 & 159.3 & 8.1 & $\underline{12.3}$ & 1.7 & 16.2 & 30 \\
\hline $\begin{array}{l}\text { Atrial } \\
\text { tetractine }\end{array}$ & Paired & 145.8 & $\underline{191.4}$ & 26.0 & 256.5 & 10.8 & $\underline{14.9}$ & 2.6 & 18.9 & 16 \\
\hline & Unpaired & 59.4 & $\underline{92.0}$ & 22.1 & 126.9 & 10.8 & $\underline{13.1}$ & 1.7 & 16.2 & 16 \\
\hline & Apical & 67.5 & 110.3 & 30.3 & 162.0 & 8.1 & 11.9 & 2.8 & 16.2 & 15 \\
\hline
\end{tabular}

L. okinoseana Hôzawa, 1929, all three from Japan. Leucandra falakra sp. nov. can be differentiated from $L$. consolida by the presence of an oscular crown in the latter (although "feebly developed"), by the absence of tetractines in the choanosome, and by the absence of the large triactines in the cortex. Moreover, the size of some spicules is different (cortical triactines: 240-350/20-25 $\mu \mathrm{m}$; choanosomal triactines - paired actines: 590-740/60-86 $\mu \mathrm{m}$, unpaired actine: $550-720 / 60-86 \mu \mathrm{m}$; atrial triactines paired actines: 220-270/15-18 $\mu \mathrm{m}$, unpaired actine: $250-300 / 15-18 \mu \mathrm{m}$; atrial tetractines: same size of the atrial triactines but with an apical actine of $80 / 14 \mu \mathrm{m})$.

Leucandra glabra has a different external morphology, with several oscula in a single individual. Besides, the size of some spicules is different (cortical triactines: 120-240/14-28 $\mu \mathrm{m}$; small choanosomal triactines: 100-200/10-20 $\mu \mathrm{m}$; large choanosomal triactines: 400-950/42-110 $\mu \mathrm{m}$; choanosomal tetractines: similar to the small choanosomal triactines but with an apical actine of $80 / 10 \mu \mathrm{m}$; atrial triactines: 90-200/12-20 $\mu \mathrm{m}$ ).

Leucandra okinoseana can be differentiated from L. falakra sp. nov. by the presence of "small protuberances for attachment" in L. okinoseana and by the size of some spicules, which are larger in the Japanese species (cortical triactines - paired actines: 120-250/16-24 $\mu \mathrm{m}$, unpaired actine: 150-350/14$16 \mu \mathrm{m}$; cortical and choanosomal large triactines: $400-1400 / 32-120 \mu \mathrm{m}$; tetractines of the canals paired actines: $150-200 / 16-20 \mu \mathrm{m}$, unpaired actine: $120-570 / 12-16 \mu \mathrm{m}$, apical actine: 70-200/8-12 $\mu \mathrm{m}$; atrial triactines - paired actines: 190-370/20-32 $\mu \mathrm{m}$, unpaired actine: 70-270/16-24 $\mu \mathrm{m}$; atrial tetractines - same size as the atrial triactines but with an apical actine of 50-110/8-16 $\mu \mathrm{m}$ ). 

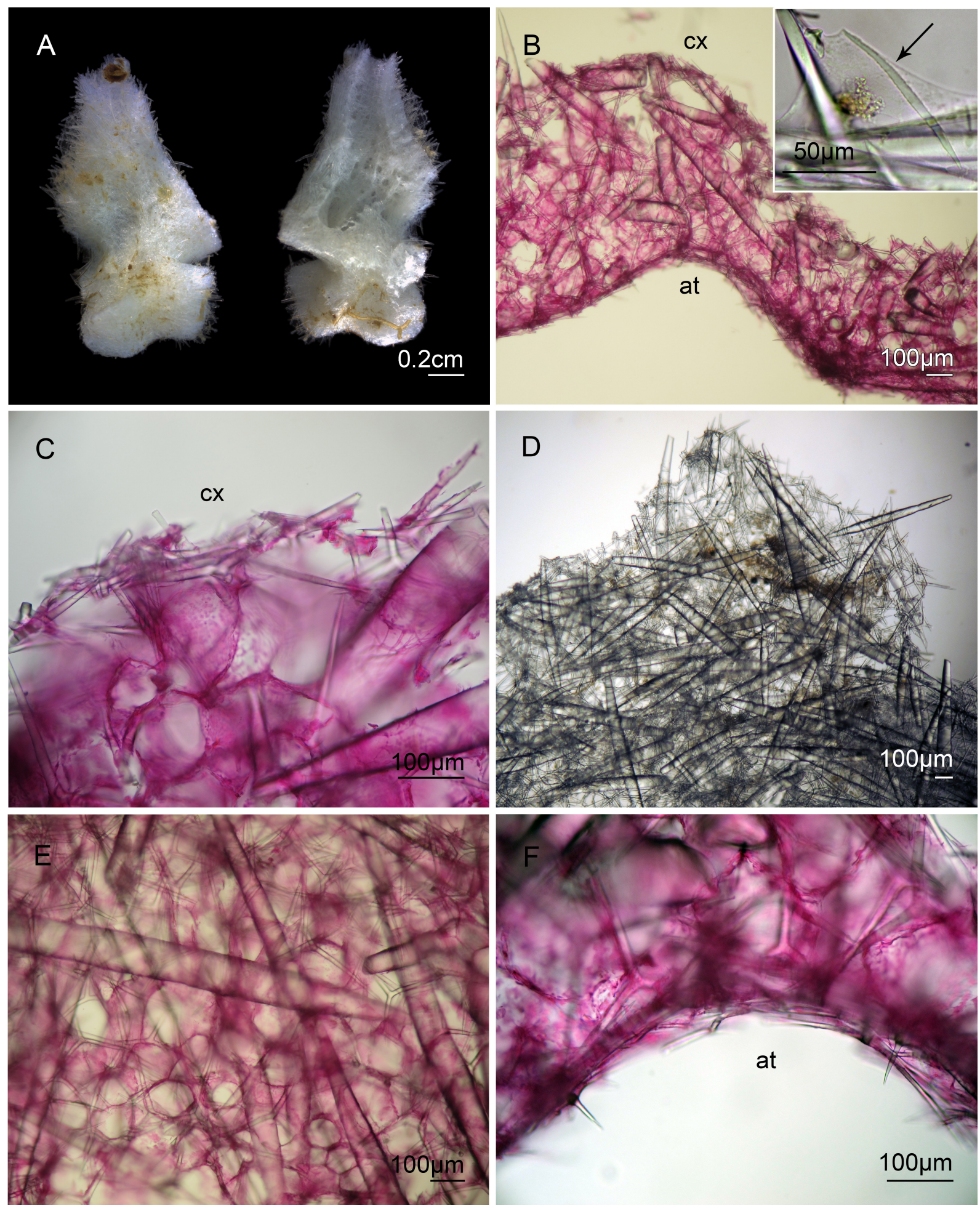

Fig. 10. Leucandra spinifera sp. nov., holotype (IRB-SG3 = UFRJPOR 8348). A. Specimen in ethanol. B. Cross section. Detail: cortical microdiactine (arrow). C. Detail of the cortex. D. Tangential section of the cortex. E. Choanosome. F. Atrial skeleton. Abbreviations: at $=$ atrium; $\mathrm{cx}=$ cortex. 


\section{Leucandra spinifera sp. nov.}

urn:1sid:zoobank.org:act:280369B2-48FF-4F3D-88E3-73317D5919A5

Figs 10-11; Table 9

\section{Etymology}

From the Latin spinifer, meaning prickly, for the presence of numerous diactines.

\section{Material examined}

\section{Holotype}

ADRIATIC SEA: Vrulja Cove, 4324'01.3" N, 1653'10.9" E, 10 m, collected by Vedran Nikolić, 24 Aug. 2011 (IRB-SG3 = UFRJPOR 8348, in ethanol).

\section{Paratype}

ADRIATIC SEA: Island of Čiovo, 432 $8^{\prime} 58.5^{\prime \prime} \mathrm{N}, 16^{\circ} 21^{\prime} 25.6^{\prime \prime} \mathrm{E}, 5 \mathrm{~m}$, collected by B. Pleše and V. Nikolić, 6 Nov. 2010 (PMR-13742 = UFRJPOR 6861, in ethanol).

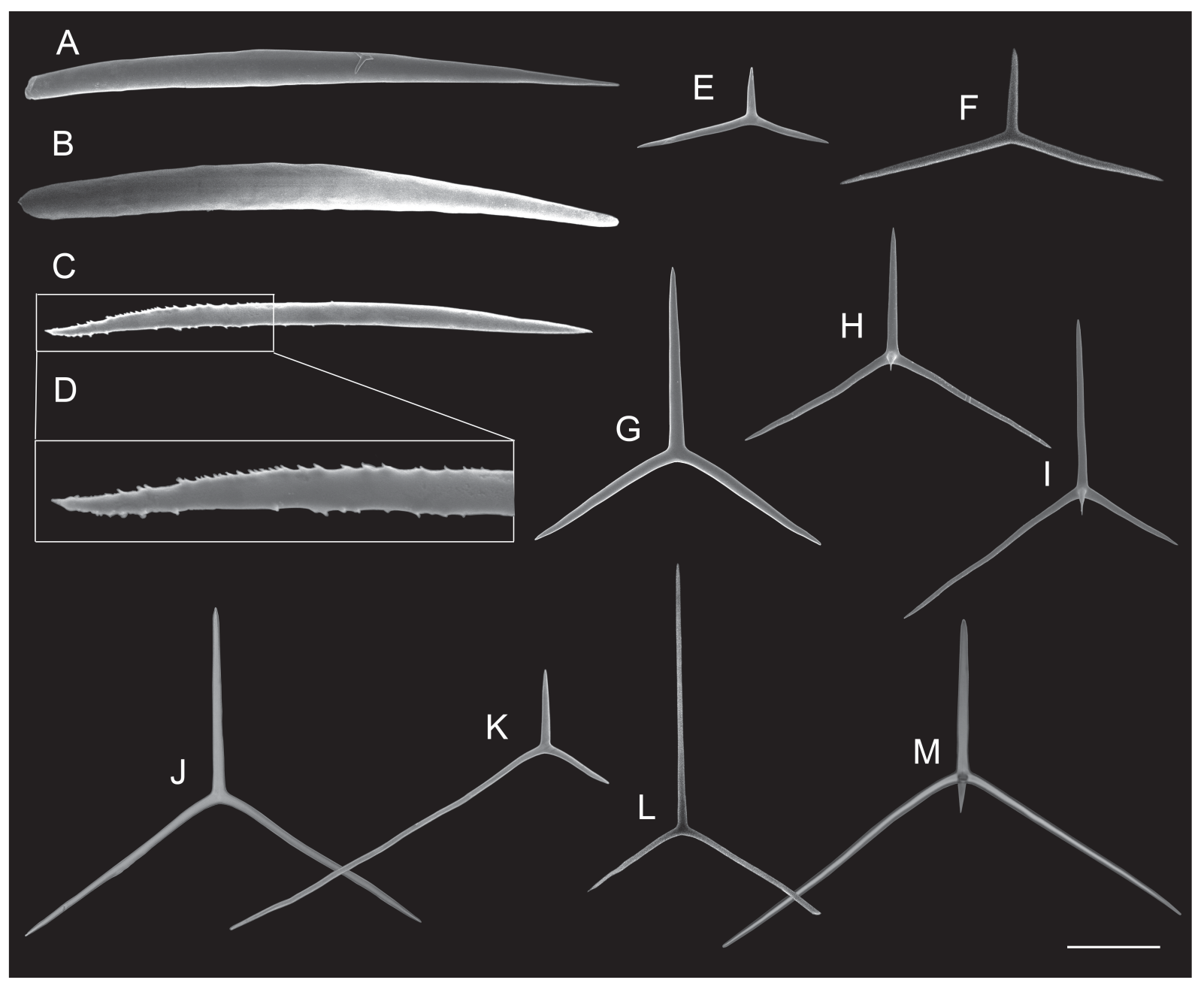

Fig. 11. Leucandra spinifera sp. nov., holotype (IRB-SG3 = UFRJPOR 8348). A-B. Cortical diactines $($ scale bar $=200 \mu \mathrm{m})$. C. Microdiactine $($ scale bar $=20 \mu \mathrm{m})$. D. Detail of the spines of a microdiactine $($ scale bar $=10 \mu \mathrm{m}) . \mathbf{E}-\mathbf{F}$. Cortical triactines. G. Choanosomal triactine. H-I. Choanosomal tetractines. J-L. Atrial triactines. M. Atrial tetractine. Scale bar E-M $=100 \mu \mathrm{m}$. 
KLAUTAU M. et al., Adriatic calcarean sponges (Porifera, Calcarea)

Table 9. Spicule measurements of Leucandra spinifera sp. nov. ( IRB-SG3 = UFRJPOR 8348).

\begin{tabular}{|c|c|c|c|c|c|c|c|c|c|c|}
\hline & & \multicolumn{4}{|c|}{ length $(\mu \mathrm{m})$} & \multicolumn{4}{|c|}{ width $(\mu \mathrm{m})$} & \\
\hline \multirow{2}{*}{\multicolumn{2}{|c|}{ Diactine }} & $\min$ & mean & $\mathrm{sd}$ & $\max$ & $\min$ & mean & $\mathrm{sd}$ & $\max$ & $\mathrm{n}$ \\
\hline & & 430.0 & $\underline{866.5}$ & 217.6 & 1400.0 & 20.0 & $\underline{54.4}$ & 16.0 & 90.0 & 17 \\
\hline \multicolumn{2}{|l|}{ Microdiactine } & 70.0 & $\underline{100.4}$ & 29.9 & 180.0 & 2.5 & $\underline{4.2}$ & 1.2 & 7.5 & 20 \\
\hline \multirow{2}{*}{$\begin{array}{l}\text { Cortical } \\
\text { triactine }\end{array}$} & Paired & 110.0 & $\underline{189.5}$ & 45.2 & 260.0 & 7.5 & 12.9 & 2.8 & 17.5 & 20 \\
\hline & Unpaired & 105.0 & $\underline{150.8}$ & 29.0 & 195.0 & 10.0 & $\underline{13.5}$ & 2.5 & 20.0 & 20 \\
\hline \multirow{2}{*}{$\begin{array}{l}\text { Choanosomal } \\
\text { triactine }\end{array}$} & Paired & 140.0 & $\underline{192.8}$ & 35.5 & 300.0 & 10.0 & $\underline{12.8}$ & 1.4 & 15.0 & 20 \\
\hline & Unpaired & 115.0 & $\underline{188.8}$ & 36.6 & 260.0 & 10.0 & $\underline{14.4}$ & 1.6 & 17.5 & 20 \\
\hline \multirow{2}{*}{ Atrial triactine } & Paired & 230.0 & $\underline{305.3}$ & 69.8 & 500.0 & 7.5 & 7.9 & 0.9 & 10.0 & 14 \\
\hline & Unpaired & 110.0 & $\underline{211.4}$ & 52.7 & 325.0 & 7.5 & $\underline{9.8}$ & 0.7 & 10.0 & 14 \\
\hline \multirow{3}{*}{$\begin{array}{l}\text { Atrial } \\
\text { tetractine }\end{array}$} & Paired & 165.0 & $\underline{276.8}$ & 63.3 & 362.5 & 7.5 & $\underline{8.4}$ & 1.1 & 10.0 & 15 \\
\hline & Unpaired & 137.5 & $\underline{222.0}$ & 62.6 & 350.0 & 7.5 & 9.7 & 0.9 & 10.0 & 15 \\
\hline & Apical & 32.5 & 42.5 & 16.8 & 67.5 & 5.0 & 6.9 & 1.6 & 8.8 & 4 \\
\hline
\end{tabular}

\section{Colour}

White in life and in ethanol.

\section{Description}

The body has the shape of a vase $(0.8 \times 0.4 \mathrm{~cm})$, with a single apical osculum surrounded by a membrane and a crown of a few, or even no trichoxeas (Fig. 10A). The osculum is supported by sagittal tetractines, but a few triactines are also present. They are organised in parallel and point their apical actines to the osculum. They become disorganized, smaller, thinner and less sagittal farther from the osculum. They are also substituted by triactines. Numerous diactines on the surface make it very hispid. The aquiferous system is leuconoid and the atrium is large (Fig. 10A). The cortical skeleton is composed of tangential triactines, perpendicular giant diactines, microdiactines and rare trichoxeas (Fig. 10B-E). The giant diactines frequently cross the entire choanosome (Fig. 10B). The choanosomal skeleton has no organisation. It is composed mainly of subregular triactines, with curved paired actines. Tetractines are also present, but only surrounding canals. The atrial skeleton has triactines and a few tetractines that project their apical actines into the atrium (Fig. 10F). Microdiactines are also present in the atrium.

Spicules (Table 9)

OSCUlAR TRIACTINES (very few) AND tetRACTINES (abundant). Sagittal. Actines are cylindrical and blunt to sharp. The unpaired actine is thinner than the paired ones. The apical actine of the tetractines is conical, sharp, smooth and strongly curved towards the osculum aperture.

TRICHOXEAS. Very thin, long and straight. They are frequently broken. These spicules are rare, but can be found in the cortex and atrium.

Diactines. Almost fusiform. The tip that penetrates the choanosome is a little larger and more rounded (Fig. 11A-B). Size: 866.5/54.4 $\mu \mathrm{m}$. 
Microdiactines. Fusiform (Fig. 11C). They are present in the cortex and atrium. They frequently have microspines (Fig. 11D), but smooth spicules are also present. Size: 100.4/4.2 $\mu \mathrm{m}$.

CORTICAL TRIACTINES. Sagittal. Actines are slightly conical, with blunt tips. The unpaired actine is shorter than the paired ones, which are curved. One of the paired actines is frequently shorter than the other (Fig. 11E-F). Size: 189.5/12.9 $\mu \mathrm{m}$ (paired actine); 150.8/13.5 $\mu \mathrm{m}$ (unpaired actine).

Choanosomal triactines. Subregular to sagittal. The paired actines are curved, consequently the unpaired angle is smaller than the paired angles. Actines are slightly conical with blunt tips. They are almost the same length (Fig. 11G). These spicules are spread in the choanosome and surrounding the canals. Size: 192.8/12.8 $\mu \mathrm{m}$ (paired actine); 188.8/14.4 $\mu \mathrm{m}$ (unpaired actine).

Choanosomal tetractines. Sagittal. The paired actines are curved, consequently the unpaired angle is smaller than the paired angles. Actines are slightly conical with blunt tips. The apical actine is straight or curved, conical, smooth and sharp (Fig. 11H-I). These spicules are present only surrounding the canals.

Atrial triactines And tetractines. Triactines are much more abundant. These spicules are strongly sagittal. The paired actines are curved and much longer than the unpaired one. Actines are slightly conical and blunt (Fig. 11J-L). The apical actine of the tetractines is straight or slightly curved near the end, conical, smooth and sharp (Fig. 11M). These tetractines are very similar to those of the choanosome. Size (triactine): 305.3/7.9 $\mu \mathrm{m}$ (paired actine); 211.4/9.8 $\mu \mathrm{m}$ (unpaired actine). Size (tetractine): 276.8/8.4 $\mu \mathrm{m}$ (paired actine); 222.0/9.7 $\mu \mathrm{m}$ (unpaired actine); 42.5/6.9 $\mu \mathrm{m}$ (apical actine).

\section{Ecology}

Specimens were collected on a cliff in a shaded area.

\section{Remarks}

This species differs from all other species of Leucandra mainly by the composition of the skeleton, particularly by the presence of mainly triactines in the atrial skeleton, with very long and slender paired actines and few spiny microdiactines in the cortex. The most similar species is the Californian L. heathi Urban, 1906. However, this species has no tetractines, while L. spinifera sp. nov. has a few tetractines. Besides, microdiactines are not abundant in $L$. spinifera sp. nov., while in $L$. heathi they form a continuous palisade in the cortex.

We found 10 species of Leucandra recorded from the Mediterranean until now, and L. spinifera sp. nov. can be differentiated from all of them: L. aspera (Schmidt, 1862) has no microdiactines; L. balearica (Lackschewitz, 1886) has only tetractines in the atrium and its microdiactines are much smaller (1224/1 $\mu \mathrm{m}$ ); L. globosa (Sarà, 1951) has different microdiactines; L. bolivari Ferrer-Hernandez, 1916 has no diactines; L. crambessa Haeckel, 1872 has no microdiactines and has tetractines only in the atrium; L. nausicaae (Schuffner, 1877) has no diactines and the atrial skeleton comprises only tetractines; $L$. riojai Ferrez-Hernandez, 1918 has only tetractines in the atrium; L. rodriguezii (Lackschewitz, 1886) has shorter microdiactines $(12-14 / 1 \mu \mathrm{m})$ which occur only in the atrium and the atrium is also composed of only tetractines; L. sulcata Ferrer-Hernandez, 1918 has microdiactines of a different shape, which are present abundantly only in the cortex, while the atrium is composed mainly of tetractines. 

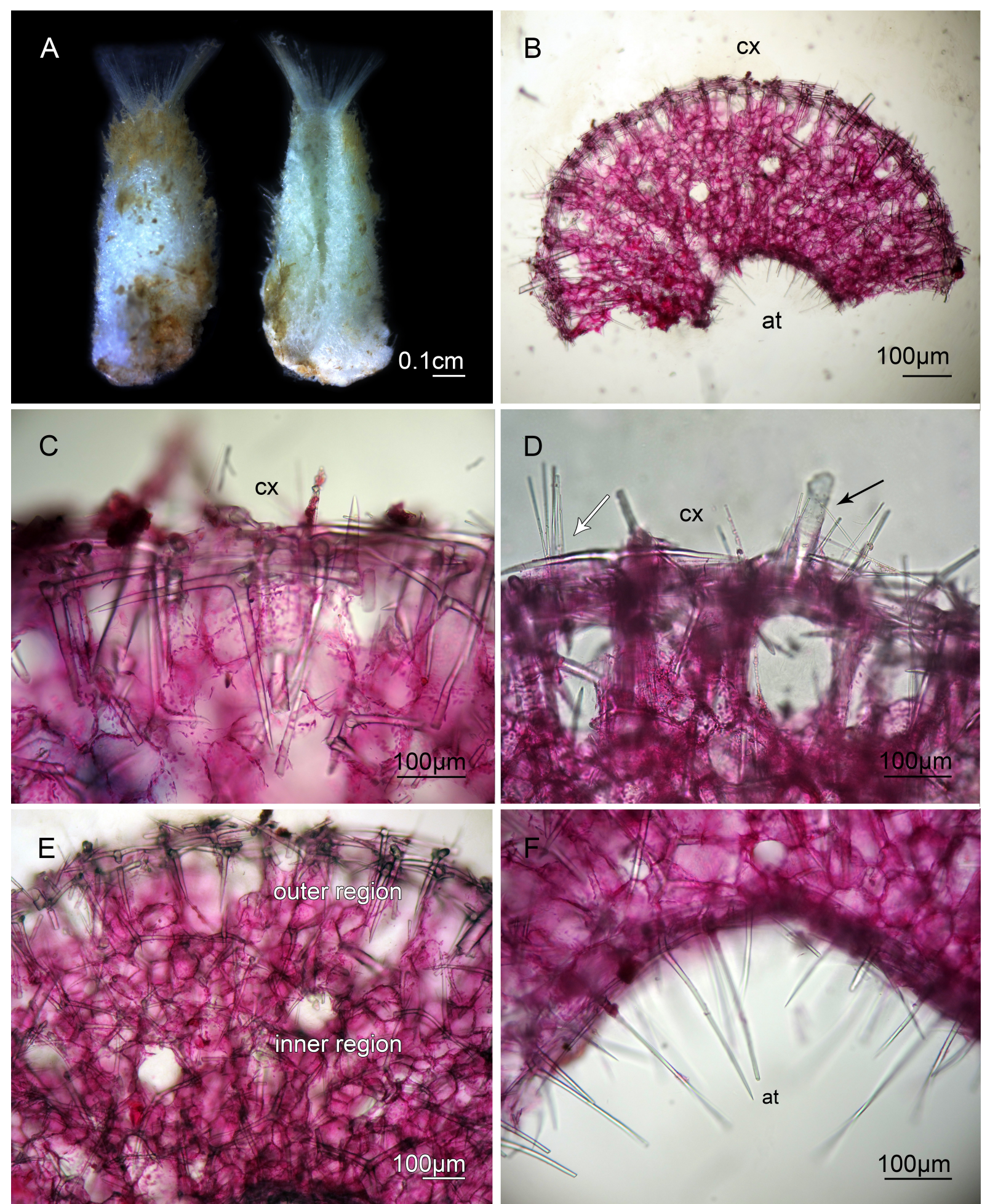

Fig. 12. Paraleucilla dalmatica sp. nov., holotype (IRB-SD5 = UFRJPOR 8346). A. Specimen in ethanol. B. Cross section. C. Cortex. D. Detail of the cortex showing the tufts of diactines (white arrow = trichoxeas; black arrow $=$ diactine) . E. Choanosome with the outer and inner regions. F. Atrial skeleton. Abbreviations: at $=$ atrium; $c x=$ cortex. 


\section{Genus Paraleucilla Dendy, 1892}

Paraleucilla dalmatica sp. nov. urn:1sid:zoobank.org:act:D066F56A-1FD7-4742-98E2-2CEE390D1E21

Figs 12-13; Table 10

\section{Etymology}

From the type locality. Dalmatia is one of the four historical regions of Croatia.

\section{Material examined}

Holotype

ADRIATIC SEA: near the Island of Čiovo, $43^{\circ} 29^{\prime} 02.0^{\prime \prime} \mathrm{N}, 16^{\circ} 22^{\prime} 10.9^{\prime \prime} \mathrm{E}, 5 \mathrm{~m}$, collected by B. Pleše and V. Nikolić, 5 Nov. 2010 (IRB-SD5 = UFRJPOR 8346, in ethanol).

Paratype

ADRIATIC SEA: same data as holotype (PMR-13747, in ethanol).

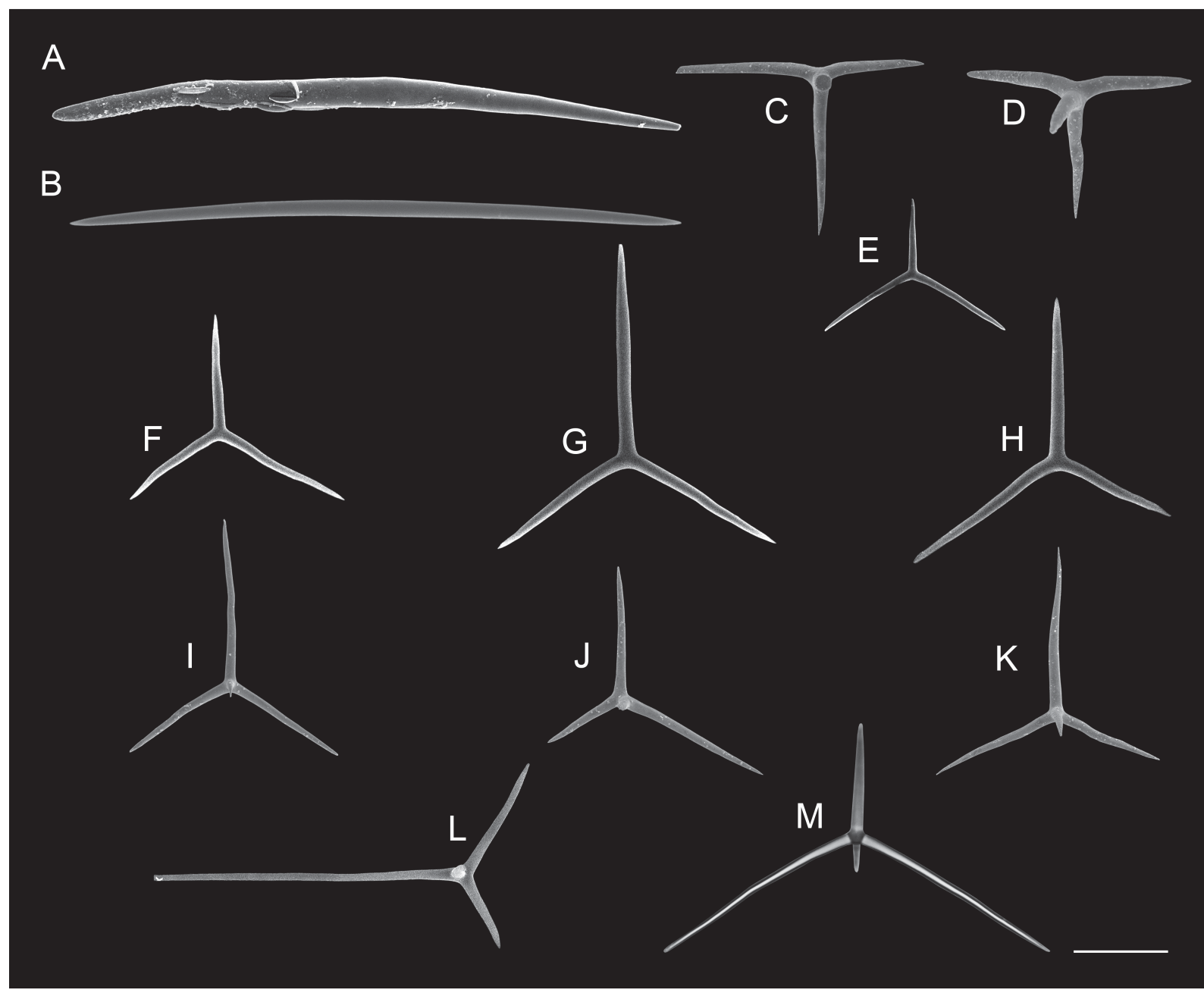

Fig. 13. Paraleucilla dalmatica sp. nov., holotype (IRB-SD5 = UFRJPOR 8346). A. Cortical diactine $($ scale bar $=50 \mu \mathrm{m})$. B. Cortical microdiactine $($ scale bar $=20 \mu \mathrm{m})$. C-D. Cortical tetractines. E. Cortical triactine. $\mathbf{F}-\mathbf{H}$. Subatrial triactines. $\mathbf{I}-\mathbf{K}$. Subatrial tetractines. $\mathbf{L}-\mathbf{M}$. Atrial tetractines. Scale bar $\mathbf{C}-\mathbf{M}=$ $100 \mu \mathrm{m}$. 
KLAUTAU M. et al., Adriatic calcarean sponges (Porifera, Calcarea)

Table 10. Spicule measurements of Paraleucilla dalmatica sp. nov. (IRB-SD5 = UFRJPOR 8346).

\begin{tabular}{|c|c|c|c|c|c|c|c|c|c|c|}
\hline & & \multicolumn{4}{|c|}{ length $(\mu \mathrm{m})$} & \multicolumn{4}{|c|}{ width $(\mu \mathrm{m})$} & \multirow[b]{2}{*}{$\mathrm{n}$} \\
\hline & & $\min$ & mean & $\mathrm{sd}$ & $\max$ & $\min$ & mean & $\mathrm{sd}$ & $\max$ & \\
\hline \multicolumn{2}{|l|}{ Diactine } & & & & 1000.0 & 25.0 & & & 50.0 & - \\
\hline \multicolumn{2}{|l|}{ Trichoxea } & & & & $>330.0$ & 2.5 & & & 5.0 & - \\
\hline \multirow{3}{*}{$\begin{array}{l}\text { Microdiactine } \\
\text { Cortical } \\
\text { triactine }\end{array}$} & & 57.5 & $\underline{95.0}$ & 23.5 & 142.5 & 2.5 & $\underline{2.5}$ & 0 & 2.5 & 15 \\
\hline & Paired & 85.0 & $\underline{142.8}$ & 35.8 & 190.0 & 5.0 & $\underline{12.4}$ & 4.3 & 20.0 & 20 \\
\hline & Unpaired & 65.0 & $\underline{149.3}$ & 48.0 & 230.0 & 5.0 & $\underline{12.9}$ & 4.7 & 20.0 & 20 \\
\hline \multirow{2}{*}{$\begin{array}{l}\text { Cortical } \\
\text { tetractine }\end{array}$} & Paired & 120.0 & $\underline{159.1}$ & 19.2 & 195.0 & 10.0 & $\underline{13.4}$ & 2.0 & 17.5 & 16 \\
\hline & Apical & 75.0 & $\underline{133.1}$ & 33.6 & 190.0 & 7.5 & $\underline{13.4}$ & 2.6 & 17.5 & 16 \\
\hline \multirow{3}{*}{$\begin{array}{l}\text { Subatrial } \\
\text { tetractine and } \\
\text { triactine }\end{array}$} & Paired & 170.0 & $\underline{180.0}$ & 7.1 & 190.0 & 12.5 & $\underline{13.2}$ & 1.2 & 15.0 & 7 \\
\hline & Unpaired & 155.0 & $\underline{205.8}$ & 26.7 & 245.0 & 10.0 & $\underline{12.7}$ & 1.1 & 15.0 & 15 \\
\hline & Apical & 23.8 & $\underline{37.8}$ & 11.9 & 50.0 & 7.5 & $\underline{8.8}$ & 1.4 & 10.0 & 4 \\
\hline \multirow{3}{*}{$\begin{array}{l}\text { Atrial } \\
\text { tetractine }\end{array}$} & Paired & 105.0 & $\underline{157.9}$ & 32.0 & 197.5 & 5.0 & $\underline{10.5}$ & 3.0 & 17.5 & 21 \\
\hline & Unpaired & 75.0 & $\underline{157.0}$ & 35.8 & 212.5 & 7.5 & 11.4 & 2.1 & 15.0 & 20 \\
\hline & Apical & 57.5 & 115.7 & 55.4 & 245.0 & 5.0 & 7.3 & 0.6 & 7.5 & 25 \\
\hline
\end{tabular}

\section{Colour}

Beige or light brown in life and white in ethanol.

\section{Description}

The body has the shape of a vase with a single apical osculum surrounded by a crown of trichoxeas (Fig. 12A). Surface is very hispid. The aquiferous system is leuconoid (Fig. 12B). The cortical skeleton is composed of the basal system of large tangential tetractines and few triactines (Fig. 12C). Giant diactines cross the surface, penetrating deeply into the choanosome. They are present from the osculum to the base of the sponge. Among these giant diactines there are also very thin and long trichoxeas, organised in tufts, and very few microdiactines (Fig. 12D). The choanosomal skeleton is characteristic of Paraleucilla, with an inarticulate region (outer region) and a zone without organisation (inner region) (Fig. 12E). The outer region is formed by the apical actine of the cortical tetractines, the unpaired actine of subatrial tetractines and very few triactines. The paired actines of these subatrial spicules are frequently curved, resembling a hook. The inner region is formed by scattered subatrial tetractines and very few triactines. The atrial skeleton is composed of tetractines only (Fig. 12F). In some parts of the sponge the inarticulate skeleton seems not to exist and it becomes more similar to Leucandrilla.

Spicules (Table 10)

OsCULAR TRIACTINES. Strongly sagittal. Actines are conical and sharp. The unpaired actine is longer and thinner than the paired ones and basipetally directed.

DiActinEs. Giant. They are present in the oscular crown and cortex. They are almost fusiform but slightly curved, with a thicker tip outside the sponge (Fig. 13A). The size is very variable. Many diatoms are attached to the diactines surrounding the osculum. Size: 1000.0/25.0-50.0 $\mu \mathrm{m}$.

TrichoXeAs. Present in the oscular crown and cortex. They are thin, straight and most of them are broken. Size: $>330.0 / 2.5-5.0 \mu \mathrm{m}$. 
Microdiactines. Very rare, fusiform or arrow-headed. Sometimes one of the tips has small spines while the other one is thicker (Fig. 13B). They are present in the cortex. Size: 95.0/2.5 $\mu \mathrm{m}$.

Cortical tetractines. Sagittal. Actines are conical with sharp tips. The apical actine is longer than the basal ones, conical, straight and sharp (Fig. 13C-D). Size: 159.1/13.4 $\mu \mathrm{m}$ (paired actine); 133.1/13.4 $\mu \mathrm{m}$ (apical actine).

CORTICAL tRIACtines. There are very few, subregular to regular. Actines are slightly conical with sharp tips (Fig. 13E). Size: 142.8/12.4 $\mu \mathrm{m}$ (paired actine); 149.3/12.9 $\mu \mathrm{m}$ (unpaired actine).

Subatrial triactines and tetractines. The triactines are rare. Actines are conical and sharp. The unpaired actine is longer than the paired ones. The paired actines are frequently strongly curved. One of them is often shorter than the other. The apical actine of the tetractines is very short, thin, smooth and strongly curved (Fig. 13F-K). Size: 180.0/13.2 $\mu \mathrm{m}$ (paired actine); 205.8/12.7 $\mu \mathrm{m}$ (unpaired actine); 37.8/8.8 $\mu \mathrm{m}$ (apical actine).

Atrial tetractines. Sagittal. Actines are slightly conical and sharp. The apical actine is slightly conical, smooth, thinner than the basal ones and straight or only slightly curved (Fig. 13L-M). Size: 157.9/10.5 $\mu \mathrm{m}$ (paired actine); 157.0/11.4 $\mu \mathrm{m}$ (unpaired actine); 115.7/7.3 $\mu \mathrm{m}$ (apical actine).

\section{Ecology}

Specimens were collected on a cliff in a shaded area.

\section{Remarks}

Currently there are 11 known species of Paraleucilla, and P. magna Klautau et al., 2004 is the only one that has been recorded in the Mediterranean Sea up to now. Both the external morphology and spicule composition differ in these two species. The most similar species to $P$. dalmatica sp. nov. are P. perlucida Azevedo \& Klautau, 2007, from Brazil, and P. princeps (Row \& Hôzawa, 1931), from Australia. Nonetheless, $P$. dalmatica sp. nov. can be differentiated from P. perlucida mainly by the absence of diactine I and trichoxea in the latter. Paraleucilla princeps also differs by the absence of diactine I and microdiactines. Therefore, $P$. dalmatica sp. nov. is the second species of Paraleucilla recorded from the Mediterranean Sea.

Genus Sycon Risso, 1826

Sycon ancora sp. nov. urn:1sid:zoobank.org:act:F39F5C07-44BF-4AC4-822D-77AA1155B018

Figs 14-15; Table 11

\section{Etymology}

From the Latin ancora, meaning anchor, for the presence of anchor-like spicules for attachment.

\section{Material examined}

Holotype

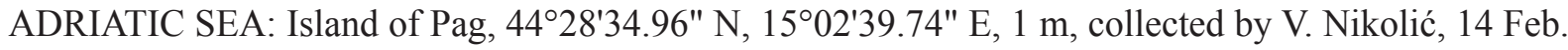
2011 (PMR $17809=$ UFRJPOR 8345, in ethanol).

\section{Paratype}

ADRIATIC SEA: near Split, 4330'27.57" N, 16²3'20.55" E, 5-10 m, collected by V. Nikolić, 15 Aug. 2011 (IRB-SD12 = UFRJPOR 8347, in ethanol). 

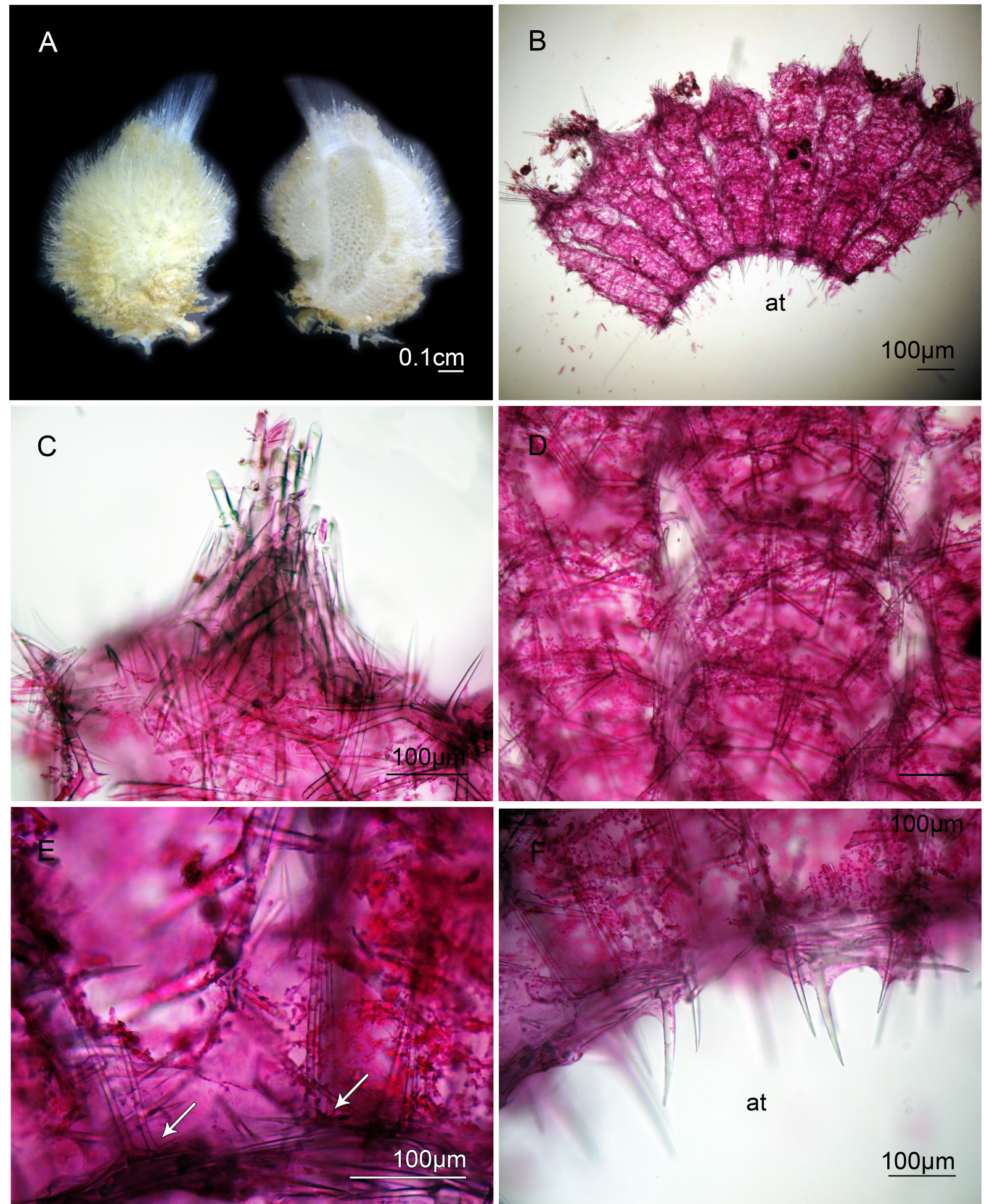

Fig. 14. Sycon ancora sp. nov., holotype (PMR $17809=$ UFRJPOR 8345). A. Specimen in ethanol. B. Cross section. C. Detail of the distal cone. D. Tubar and subatrial skeletons. E. Atrial skeleton (white arrows $=$ subatrial triactines). $\mathbf{F}$. Tangential section of the atrial skeleton. Abbreviation: at $=$ atrium. 


\section{Colour}

White in life and in ethanol.

\section{Description}

The body is vase-shaped $(1.1 \times 0.8 \mathrm{~cm})$, with a single apical osculum surrounded by a crown of trichoxeas (Fig. 14A) and diactines supported by sagittal tetractines. These tetractines are arranged parallel to each other and their unpaired actines are basipetally directed. The unpaired actine is longer and thinner than the paired ones and the apical actine is curved towards the osculum aperture. The paired actines are slightly curved. There is no suboscular region. The aquiferous system is syconoid and the atrium is central. The radial tubes are coalescent (Fig. 14B). Diactines and trichoxeas protrude through the distal cones; consequently, the surface is very hispid. These diactines (ca 10 to 15) penetrate only a little into the sponge surface (Fig. 14C). The unpaired actine of some triactines also protrudes through the cones.

The tubar skeleton is articulated, but not so well organised as in most sycons (Fig. 14D). It is composed of rows of sagittal triactines that point their unpaired actines to the surface. These tubar triactines are

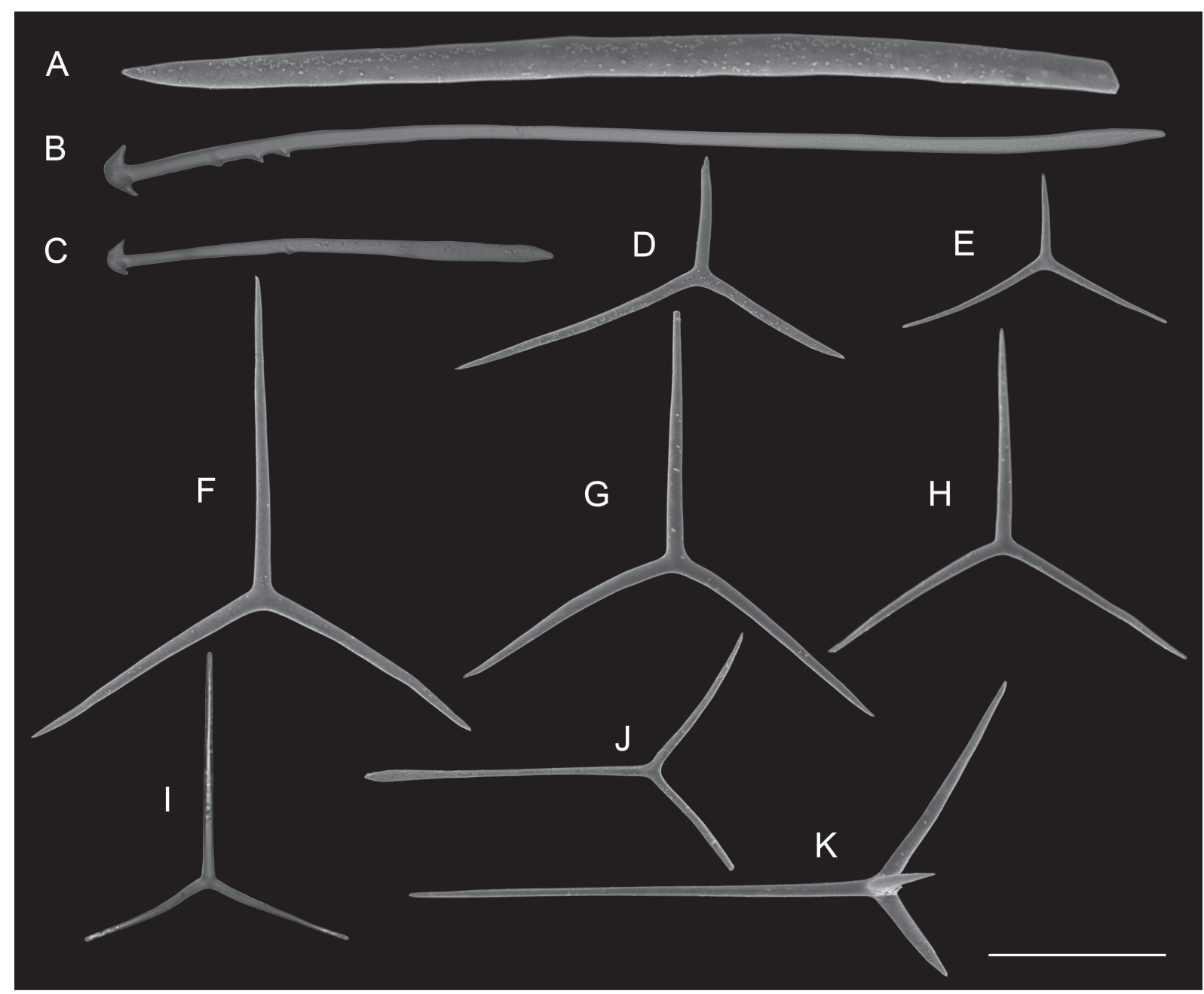

Fig. 15. Sycon ancora sp. nov., holotype (PMR 17809 = UFRJPOR 8345). A. Cortical diactine. B-C. Anchor-like tetractines. D-E. Triactines of the cones. F-H. Tubar triactines. I. Subatrial triactine. J. Atrial triactine. K. Atrial tetractine. Scale bar D-K $=100 \mu \mathrm{m}$. 
KLAUTAU M. et al., Adriatic calcarean sponges (Porifera, Calcarea)

Table 11. Spicule measurements of Sycon ancora sp. nov. (PMR $17809=$ UFRJPOR 8345).

\begin{tabular}{|c|c|c|c|c|c|c|c|c|c|c|}
\hline & & \multicolumn{4}{|c|}{ length $(\mu \mathrm{m})$} & \multicolumn{4}{|c|}{ width $(\mu \mathrm{m})$} & \multirow[b]{2}{*}{$\mathrm{n}$} \\
\hline & & $\min$ & mean & $\mathrm{sd}$ & $\max$ & $\min$ & mean & $\mathrm{sd}$ & $\max$ & \\
\hline \multicolumn{2}{|l|}{ Diactine } & 378.0 & 537.8 & 180.1 & 800.0 & 10.8 & $\underline{16.1}$ & 4.5 & 20 & 6 \\
\hline \multicolumn{2}{|l|}{$\begin{array}{l}\text { Anchor-like } \\
\text { tetractine }\end{array}$} & - & - & - & $>1000$ & 25.0 & & & 37.5 & 2 \\
\hline \multirow{2}{*}{$\begin{array}{l}\text { Triactine } \\
\text { (distal cone) }\end{array}$} & Paired & 59.4 & $\underline{112.3}$ & 27.2 & 148.5 & 5.4 & $\underline{6.9}$ & 1.4 & 10.8 & 20 \\
\hline & Unpaired & 54.0 & 78.6 & 18.7 & 124.2 & 5.4 & $\underline{7.0}$ & 1.5 & 10.8 & 20 \\
\hline \multirow{2}{*}{$\begin{array}{l}\text { Tubar } \\
\text { triactine }\end{array}$} & Paired & 116.1 & 168.2 & 25.8 & 216.0 & 8.1 & $\underline{13.0}$ & 2.7 & 16.2 & 20 \\
\hline & Unpaired & 143.1 & $\underline{188.1}$ & 29.6 & 259.2 & 8.1 & $\underline{12.4}$ & 2.8 & 18.9 & 20 \\
\hline \multirow{2}{*}{$\begin{array}{l}\text { Subatrial } \\
\text { triactine and } \\
\text { tetractine }\end{array}$} & Paired & 67.5 & $\underline{97.9}$ & 41.6 & 159.3 & 4.1 & $\underline{5.4}$ & 1.1 & 6.8 & 4 \\
\hline & Unpaired & 108.0 & $\underline{212.4}$ & 36.5 & 264.6 & 4.1 & $\underline{6.0}$ & 1.5 & 8.1 & 21 \\
\hline \multirow{3}{*}{$\begin{array}{l}\text { Atrial } \\
\text { tetractine I }\end{array}$} & Paired & 94.5 & $\underline{153.5}$ & 31.7 & 202.5 & 7.6 & $\underline{10.8}$ & 2.1 & 16.2 & 17 \\
\hline & Unpaired & 55.1 & $\underline{219.4}$ & 75.8 & 332.1 & 7.6 & $\underline{10.7}$ & 1.5 & 13.5 & 17 \\
\hline & Apical & 97.5 & $\underline{123.8}$ & 21.9 & 177.5 & 8.8 & $\underline{11.4}$ & 1.4 & 12.5 & 20 \\
\hline \multirow{3}{*}{$\begin{array}{l}\text { Atrial } \\
\text { tetractine II }\end{array}$} & Paired & - & $\underline{162.5}$ & - & - & - & $\underline{6.3}$ & - & - & 1 \\
\hline & Unpaired & - & 137.5 & - & - & - & $\underline{6.3}$ & - & - & 1 \\
\hline & Apical & 50.0 & 77.1 & 14.5 & 112.5 & 5.0 & $\underline{5.6}$ & 1.0 & 7.5 & 20 \\
\hline
\end{tabular}

larger than those of the distal cones and the paired actines are frequently curved. The subatrial skeleton is composed of sagittal triactines and tetractines (Fig. 14E) with very thin actines. The unpaired actine is much longer than the paired ones and the longest ones are frequently localized among the choanocyte chambers. They point their unpaired actines towards the distal cones. Some of the subatrial triactines are similar to pseudosagittal spicules. The atrial skeleton is composed of two categories of tetractines tangentially organized (Fig. 14E). They frequently have long, unpaired and short, paired actines. One of the paired actines is commonly shorter than the other; however, the three basal actines can have the same size (Fig. 14F). When one of the paired actines is shorter than the other, it frequently penetrates an exhalant canal. The main difference between the two categories of atrial tetractines is in the apical actine. Tetractines with thinner apical actines project these actines mainly into the canals, while thicker and curved apical actines penetrate into the atrium (Fig. 14E). Few anchor-like tetractines are present at the sponge base and project their basal actines into the substrate.

Spicules (Table 11)

Diactines. Almost fusiform, but the tip outside the sponge is a little thicker (Fig. 15A). Size: $537.8 / 16.1 \mu \mathrm{m}$.

TRICHOXEAS. Very thin, long and straight. They were always broken.

ANCHOR-LIKE TETRACTINES. The basal actines are very short and curved, while the apical one is very long. Frequently there are spines on the apical actine, but near the basal ones. They vary from four to seven, but seven spines are more common (Fig. 15B). Size: > 1000.0/25.0 $\mu \mathrm{m}$. 
TRIACTINES OF THE CONES. They are smaller than the tubar triactines. The unpaired actine protrudes through the cones and it is shorter than the paired ones, which are curved. Actines are slightly conical and sharp (Fig. 15C-D). Size: 112.3/6.9 $\mu \mathrm{m}$ (paired actine); 78.6/7.0 $\mu \mathrm{m}$ (unpaired actine).

TRIACTINES OF THE tUBES. Subregular to sagittal. The unpaired actine is a little longer or has the same length of the paired ones. The paired actines are straight or slightly curved. Actines are slightly conical and sharp (Fig. 15E-G). Size: 168.2/13.0 $\mu \mathrm{m}$ (paired actine); 188.1/12.4 $\mu \mathrm{m}$ (unpaired actine).

Subatrial triactines And tetractines. The subatrial spicules are very thin. They are sagittal or, sometimes, similar to pseudosagittal spicules. Actines are slightly conical and sharp. The unpaired actine is longer than the paired ones (Fig. 15H). The apical actine of the tetractines is conical, sharp, smooth, shorter than the basal ones and curved in the direction of the atrium. Size: $97.9 / 5.4 \mu \mathrm{m}$ (paired actine); 212.4/6.0 $\mu \mathrm{m}$ (unpaired actine).

Atrial tetractines I AND II AND tRiactines. There are two categories of atrial tetractines and the triactines are very rare. They are sagittal or subregular. The unpaired actine is frequently longer than the paired ones (Fig. 15I). It is also common to find one of the paired actines shorter than the other (63.5109.3( \pm 64.7$)-155.0 / 10-11.3( \pm 1.8)-12.5 \mu \mathrm{m}(\mathrm{n}=2)$; Fig. 15J). This shorter, paired actine is frequently projected inside the exhalant canal. Actines are cylindrical and sharp. Sometimes, the tip of the unpaired actine is thicker (Fig. 15I). The main difference between the two categories of tetractines is in the shape and size of the apical actines, which are straight and thinner in one and curved and thicker in the other. Size (tetractine I): 153.5/10.8 $\mu \mathrm{m}$ (paired actine); 219.4/10.7 $\mu \mathrm{m}$ (unpaired actine); 123.8/11.4 $\mu \mathrm{m}$ (apical actine). Size (tetractine II): 162.5/6.3 $\mu \mathrm{m}$ (paired actine); 137.5/6.3 $\mu \mathrm{m}$ (unpaired actine); 77.1/5.6 $\mu \mathrm{m}$ (apical actine).

\section{Ecology}

Specimens were collected on a semi-vertical hard limestone bottom. They were found among Cystoseira macroalgae.

\section{Remarks}

Currently there are 12 accepted species of Sycon in the Mediterranean Sea, 10 of which have already been reported for the Adriatic. We compared our specimens to all known species of Sycon and even more carefully to the Mediterranean ones, yet we could not find a perfect match.

The main characteristic discerning Sycon ancora sp. nov. from other species is the shape of the atrial triactines and the presence of anchor-like tetractines at the base. If we exclude these characteristics, this species would be mostly comparable to S. raphanus; however, there are several important differences between them.

Sycon raphanus was originally described from the Adriatic Sea by Schmidt (1862). Unfortunately, his description was not detailed enough. According to him, S. raphanus has a bulb shape and a peduncle. He even considered these characteristics to distinguish S. raphanus from S. ciliatum (Fabricius, 1780), a species from the English Channel which he believed to be present in the Adriatic Sea.

Haeckel (1872) disagreed with the possibility of S. ciliatum occurring in the Mediterranean Sea and considered that all specimens called $S$. ciliatum were, in fact, $S$. raphanus. He also mentioned that he analysed all the specimens from Schmidt's collection identified as $S$. raphanus and found a potpourri of species, including Leucandra aspera, Sycon humboldti, Sycon setosum and "the real S. raphanus". Therefore, he made a detailed description of this species, which has since then been considered as the official description of $S$. raphanus. According to his description, S. raphanus is morphologically very variable, solitary or not, with or without peduncle. The skeleton is composed of tufts of 5-10 cylindrical 
diactines (var. tergestina) to 20-50 diactines (var. procumbens) and the size of the diactines varies from $400-800 / 20-30 \mu \mathrm{m}$ up to $1000-2000 / 20-40 \mu \mathrm{m}$, rarely attaining $3000 \mu \mathrm{m}$. Analyzed specimens of S. ancora sp. nov. have tufts of 10-15 diactines measuring $378 \rightarrow 1500 / 10.8-18.9 \mu \mathrm{m}$. Sycon raphanus has triactines with curved paired actines in the distal cones and in the tubar skeleton. The tubar triactines are 100-180/10-12 $\mu \mathrm{m}$ (paired) and 150-250/10-12 $\mu \mathrm{m}$ (unpaired), which are thinner than in S. ancora sp. nov. The subatrial skeleton of $S$. raphanus has triactines (paired: 100-180/5-8 $\mu$ m; unpaired: 150250/5-8 $\mu \mathrm{m}$ ), while $S$. ancora sp. nov. has triactines and tetractines. The atrial skeleton of $S$. raphanus shows subregular to regular (rarely sagittal) triactines and tetractines (basal: 150-250/8-10 $\mu \mathrm{m}$; apical: 60-120 $\mu \mathrm{m}$ ), while our species has tetractines with two types of apical actines (there is a variation in the thickness and position), a long unpaired actine and paired actines with different sizes. Haeckel (1872) also mentioned the presence of only triactines supporting the oscular crown, while $S$. ancora sp. nov. has only tetractines.

Although we believe the entire genus Sycon is in urgent need of revision, the characteristics we found in our specimens strongly indicate the presence of a new species.

\section{Other calcarean species from the Adriatic Sea}

Apart from the species described here, we also recorded and molecularly analyzed specimens of Clathrina blanca (Miklucho-Maclay, 1868), C. clathrus (Schmidt, 1864), C. rubra Sarà, 1958 and Paraleucilla

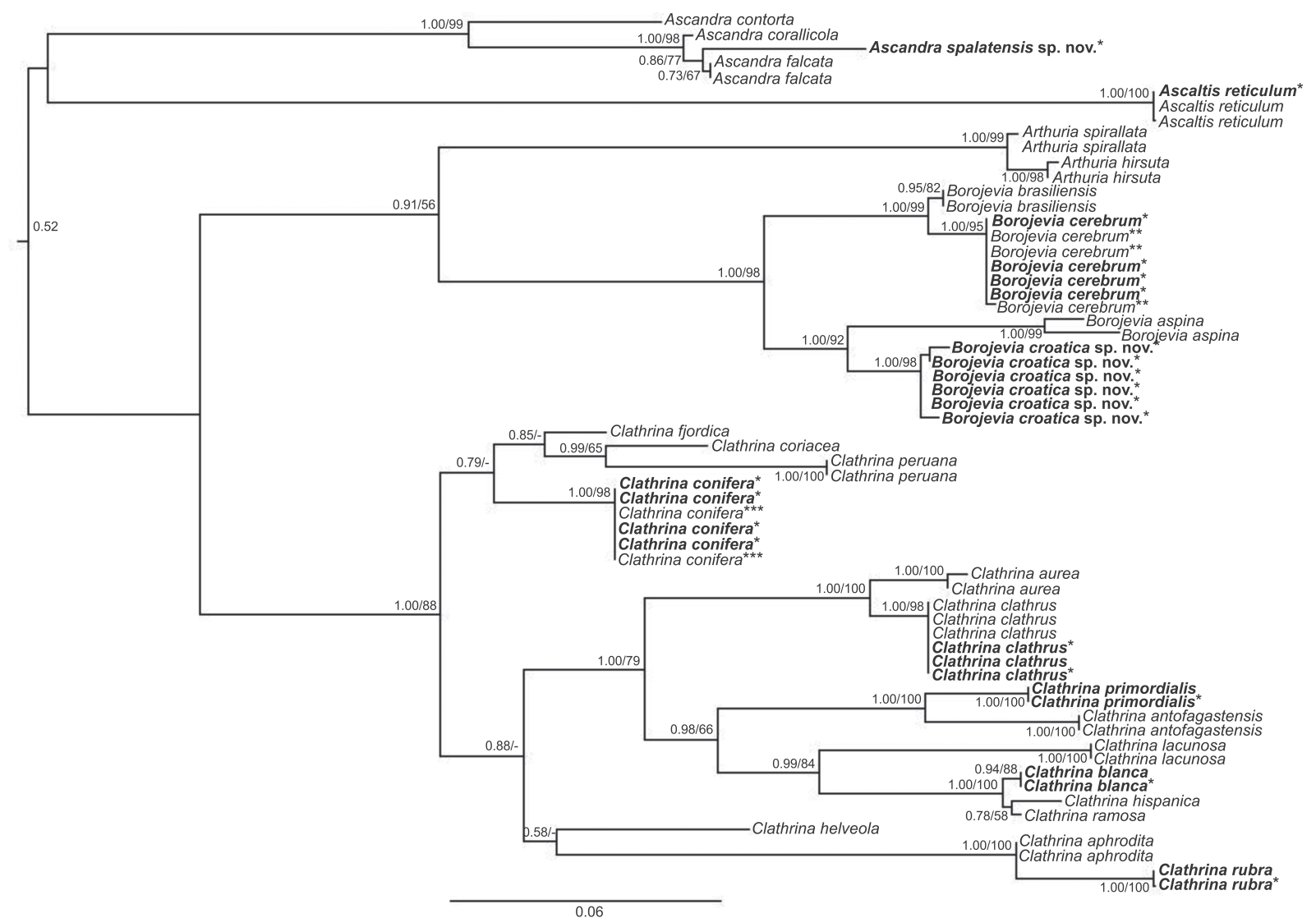

Fig. 16. Maximum likelihood (ML) tree based on ITS1-5.8S-ITS2 rDNA sequences of Calcinea. Bayesian posterior probabilities (PP) and bootstrap values (BS) are given near the branches (PP/BS; when $>0.50$ ). Adriatic specimens are written in bold; *Adriatic specimens obtained during this study; **Mediterranean specimens of Borojevia cerebrum; ***Brazilian specimens of Clathrina conifera. 
magna Klautau, Monteiro \& Borojević, 2004. These species are not redescribed here, since specimens from the Adriatic Sea have already been recorded and described in earlier works (Cvitković et al. 2013; Imešek et al. 2014). In the present study, C. blanca was recorded near Selce $\left(45^{\circ} 09^{\prime} 07.8^{\prime \prime} \mathrm{N}, 14^{\circ} 43^{\prime} 15.0^{\prime \prime}\right.$ E ), about $1 \mathrm{~m}$ deep and C. rubra was recorded near the Island of Čiovo $\left(43^{\circ} 28^{\prime} 58.5^{\prime \prime} \mathrm{N}, 16^{\circ} 21^{\prime} 25.6^{\prime \prime}\right.$ E), about 5m deep on a shaded hard bottom. In August and November 2010 they were quite abundant, always only a few millimeters in size and often found on bryozoans. C. clathrus was found in numerous locations along the coast (e.g., Prapratno Cove, $42^{\circ} 48^{\prime} 36.8^{\prime \prime} \mathrm{N}, 17^{\circ} 40^{\prime} 38.4^{\prime \prime} \mathrm{E}$; near the Island of Čiovo, $43^{\circ} 28^{\prime} 58.5^{\prime \prime} \mathrm{N}, 16^{\circ} 21^{\prime} 25.6^{\prime \prime} \mathrm{E}$ ) and the cryptogenic species P. magna was found in large numbers in on aquaculture installations in Grška Cove on the Island of Brač and in the Port of Ploče.

\section{Molecular analysis}

The number of sites used for the final alignments (gaps included) was as follows: 513 for ITS Calcinea, 1434 for 28S Calcinea, 734 for ITS Calcaronea and 846 for 28S Calcaronea. Both markers revealed the same tree topology in both analyses (but see Fig. 19), yet the Bayesian analysis rendered much better support values than ML in all cases. However, the Adriatic species nested within the respective genera with high bootstrap (BS) and posterior probability (PP) values, thereby confirming the results of morphological analysis (Figs 16-19).

Once more the presence of diactines did not show any phylogenetic signal (Rossi et al. 2011; Klautau et al. 2013). Furthermore, we found former guanchas with only triactines reunited in a monophyletic clade in the ITS analysis, with high support values inside the Clathrina group (0.99 PP and 0.84 BS; Fig. 16). In the $28 \mathrm{~S}$ calcinean tree (Fig. 17) we recovered a clade where Levinella represents a sister

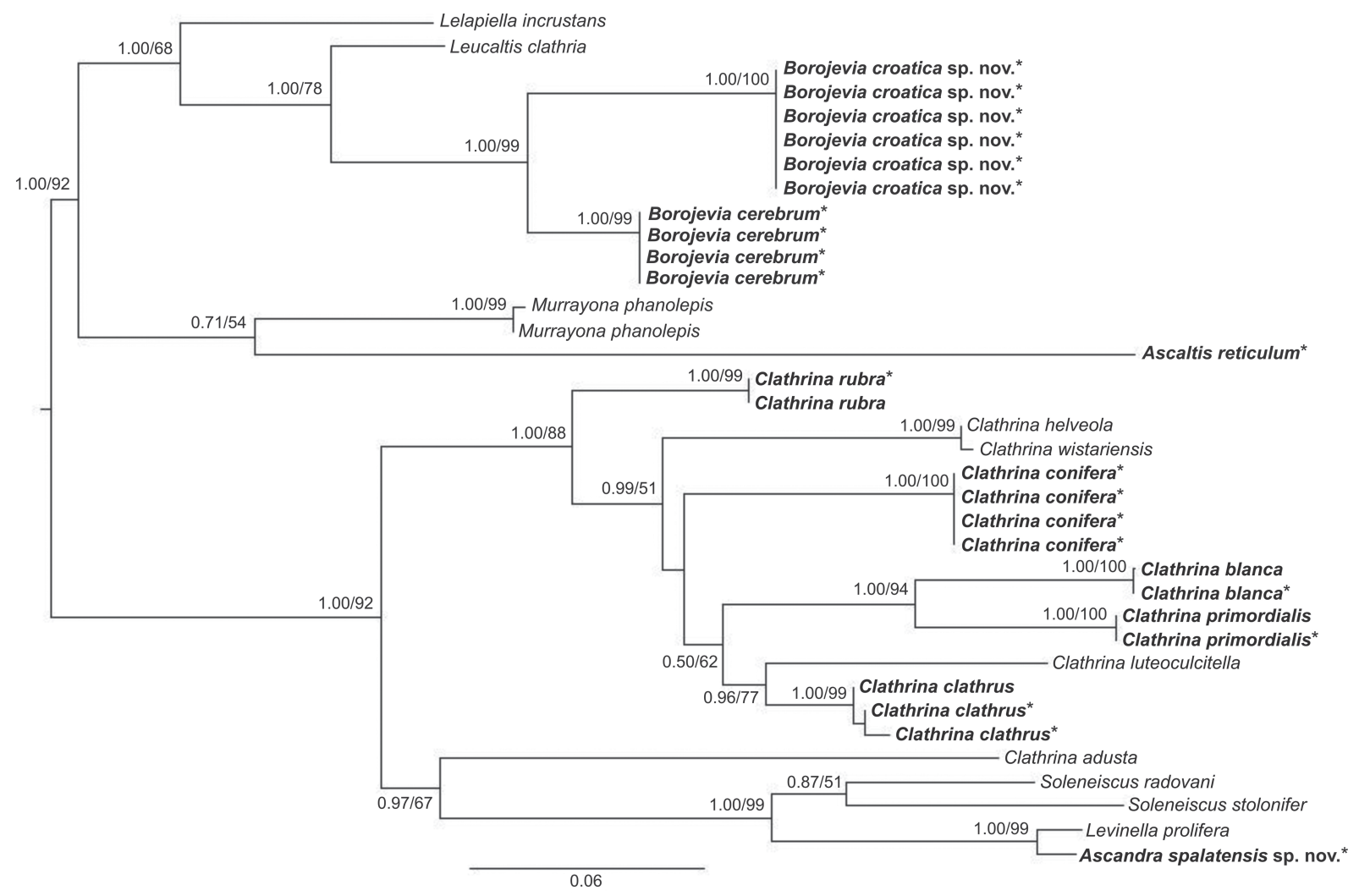

Fig. 17. Maximum likelihood tree (ML) based on partial 28S rDNA sequences of Calcinea. Bayesian posterior probabilities (PP) and bootstrap values (BS) are given near the branches (PP/BS; when $>0.50$ ). Adriatic species are written in bold. Adriatic specimens obtained in this study are marked with an asterisk. 
group to Ascandra with high support values (1.00 PP and $0.99 \mathrm{BS}$ ), which confirms the results of Voigt et al. (2012). We also recovered a clade comprising the genera Murrayona and Ascaltis in both analyses; however, the support values were less good (0.71 PP and 0.54 BS). The molecular analyses also confirmed the presence of P. magna in the Adriatic Sea (Figs 18-19). Besides, we recovered a calcaronean clade with high support (1.00 PP and 0.99 BS in ITS analysis; 0.95 PP and 0.64 BS in 28S analysis) formed only by Paraleucilla species. The genus Paraleucilla formed a highly supported clade with Leucandra nicolae, while Leucandra spinifera sp. nov. is a sister species of $L$. aspera (Fig. 19). Sycon ancora sp. nov. represents a sister species of $S$. raphanus (Fig. 19). We confirmed the paraphyly of the genera Sycon and Leucandra (Voigt et al. 2012).

\section{Species richness}

Considering previous data, together with our present results based on morphological and molecular analyses, we found a total of 13 species of Calcinea (Table 12) and 26 of Calcaronea in the Adriatic Sea (Table 13). Taking into account the species richness by sectors (Fig. 20), the richest sector is the Central Adriatic, where 34 species were found, followed by the Northern Adriatic with 18, and the Southern Adriatic with only 5 species. Most of the species present in the Adriatic Sea are also present in other Mediterranean areas, yet, altogether we recorded six species provisionally endemic for the Adriatic, two calcinean and four calcaronean.

\section{Discussion}

Since some of the first studies on the class Calcarea were mainly done along the Dalmatian coast by Schmidt and Haeckel in the $19^{\text {th }}$ century (e.g., Schmidt 1862, 1864; Haeckel 1870, 1872), the knowledge of the current species diversity and distribution certainly awakes taxonomic interest. Analysing previous

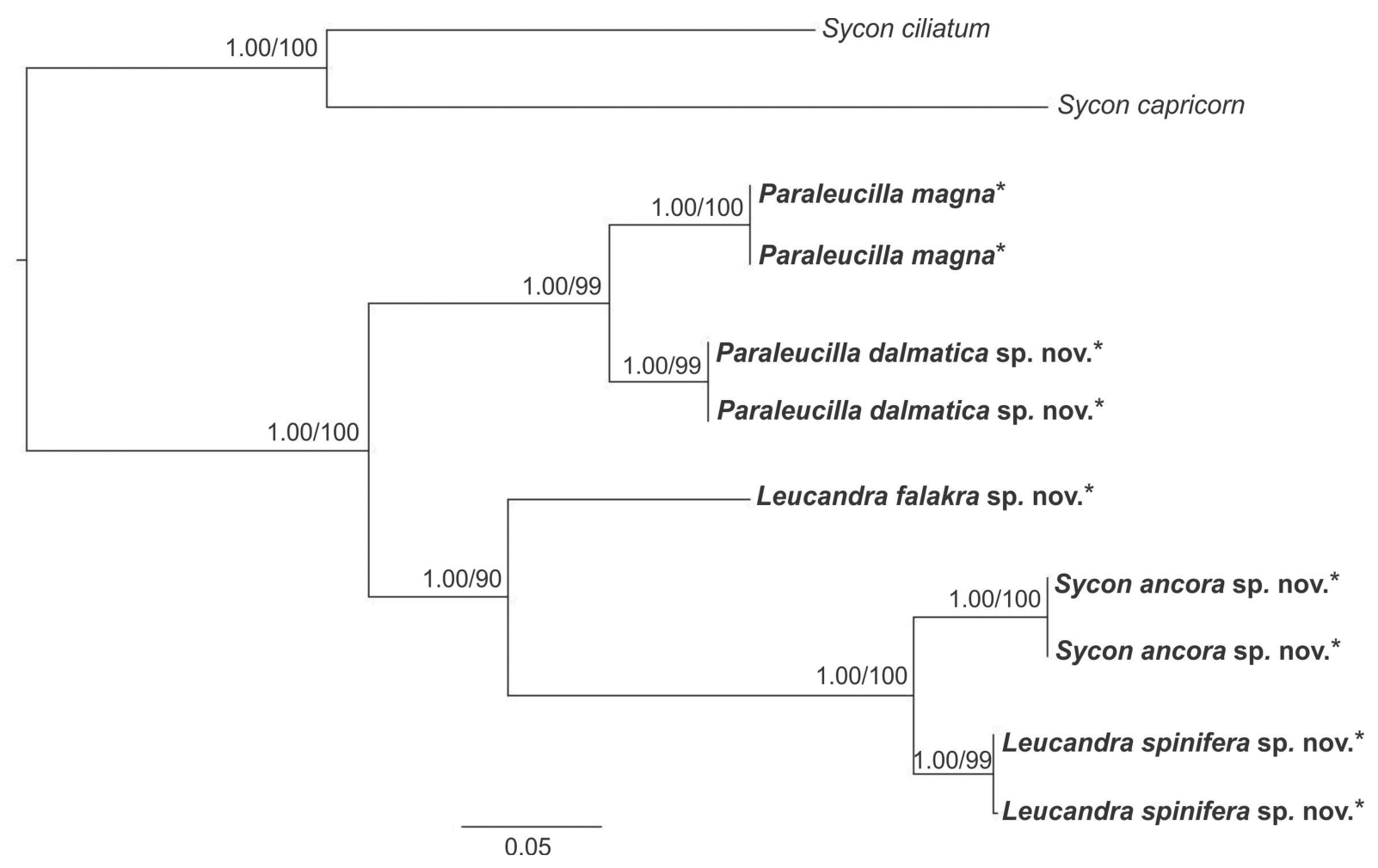

Fig. 18. Maximum likelihood tree based on ITS1-5.8S-ITS2 rDNA sequences of Calcaronea. Bayesian posterior probabilities (PP) and bootstrap values (BS) are given near the branches ( $\mathrm{PP} / \mathrm{BS}$; when $>0.50$ ). Adriatic species are written in bold. Adriatic specimens obtained in this study are marked with an asterisk. 
results with ours, we found a total of 39 species of calcarean sponges in the Adriatic Sea (Tables 12-13). In this species list we do not consider the records of Clathrina coriacea (Montagu, 1814), Sycon ciliatum (Fabricius, 1780) or S. proboscideum (Haeckel, 1870). The occurrence of C. coriacea was not considered because, analysing the descriptions of this species for the Adriatic Sea, we think that they most probably represent C. conifera or C. primordialis. Sycon ciliatum seems to be restricted to the North Atlantic and was probably mistaken for S. raphanus (Haeckel, 1872). Sycon proboscideum is a species from the Red Sea and its occurrence in the Adriatic Sea was mentioned only by Breitfuss (1935), which suggested that some specimens previously identified as $S$. raphanus could in fact be $S$. proboscideum. He did not give a description or any further clues. Therefore, the occurrence of this species in the Adriatic Sea has to be verified (Burton 1963; Longo \& Pronzato 2011).

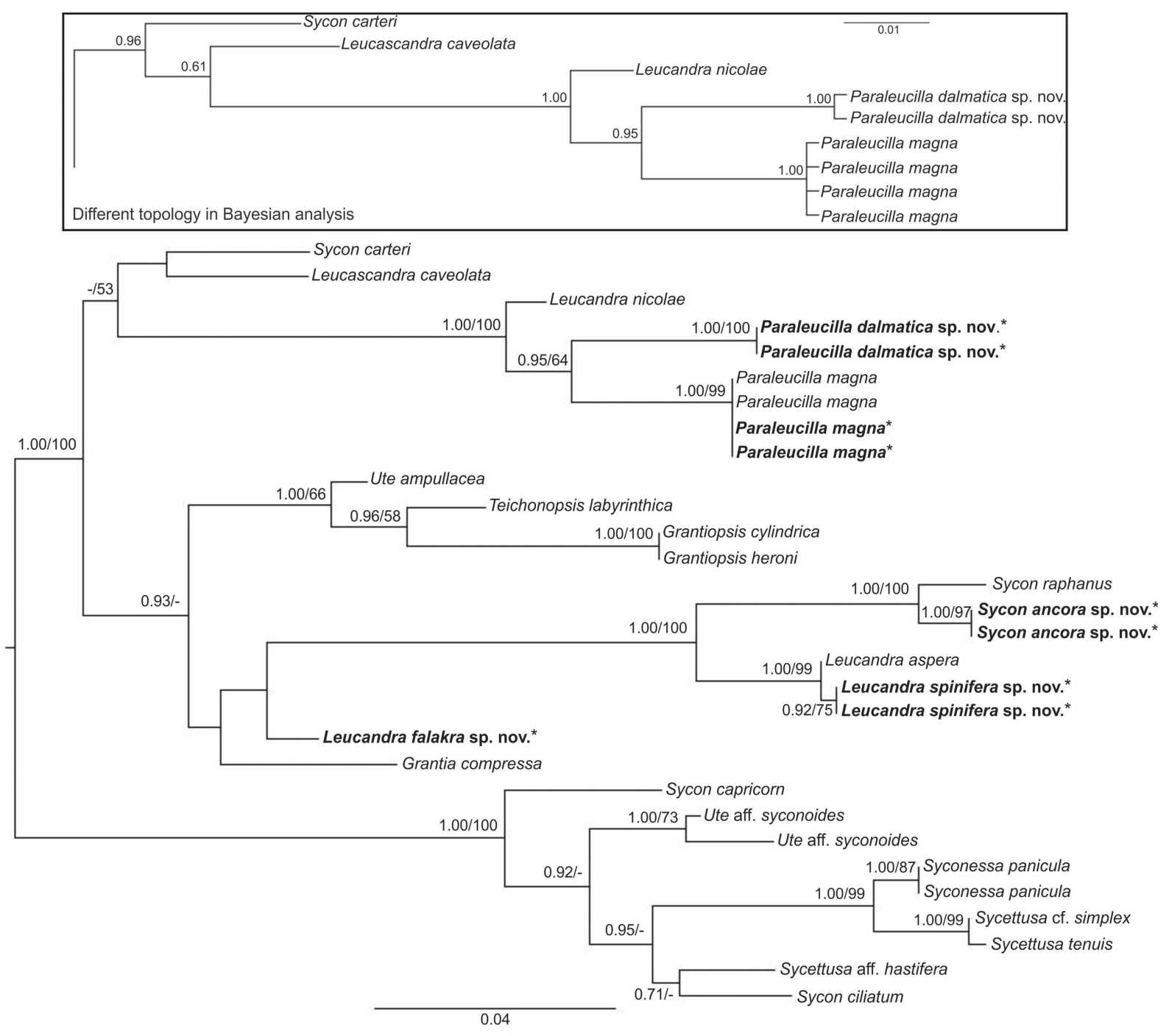

Fig. 19. Maximum likelihood tree based on partial 28S rDNA sequences of Calcaronea. Bayesian posterior probabilities (PP) and bootstrap values (BS) are given near the branches ( $\mathrm{PP} / \mathrm{BS}$; when $>0.50$ ). Adriatic specimens are written in bold. Adriatic specimens obtained in this study are marked with an asterisk. The detached tree shows the only difference in the topology of the ML and Bayesian analyses. 
KLAUTAU M. et al., Adriatic calcarean sponges (Porifera, Calcarea)

Table 12. Calcinean species reported from the Adriatic Sea and their distribution. *Type locality. ** Probably Clathrina conifera or C. primordialis.

\begin{tabular}{|c|c|c|c|c|}
\hline Species & $\begin{array}{c}\text { Longitude } \\
(\mathrm{N})\end{array}$ & $\begin{array}{c}\text { Latitude } \\
\text { (E) }\end{array}$ & Locality & Source \\
\hline Ascaltis reticulum (Schmidt, 1862) & 15.22 & 44.10 & Zadar $=$ Zara $*$ & Schmidt 1862 \\
\hline Ascaltis reticulum (Schmidt, 1862) & 15.92 & 43.73 & Šibenik $=$ Sebenico $*$ & Schmidt 1862 \\
\hline Ascaltis reticulum (Schmidt, 1862) & 16.73 & 43.13 & Hvar $=$ Lesina & $\begin{array}{l}\text { Schmidt } 1862 \text { (according to } \\
\text { Haeckel 1872); Heller } 1864 \\
\text { (apud Haeckel 1872); Haec- } \\
\text { kel } 1872\end{array}$ \\
\hline Ascaltis reticulum (Schmidt, 1862) & 13.63 & 45.08 & Rovinj & Longo \& Pronzato 2011 \\
\hline Ascaltis reticulum (Schmidt, 1862) & 16.36 & 43.48 & Island of Čiovo & Present work \\
\hline $\begin{array}{l}\text { Ascandra contorta Bowerbank, } \\
1866 \text { (sensu Minchin 1905) }\end{array}$ & 15.5 & 42.12 & Tremiti Island & $\begin{array}{l}\text { Lendenfeld } 1891 \text { (as Ascetta } \\
\text { spinosa); Sarà } 1961\end{array}$ \\
\hline $\begin{array}{l}\text { Ascandra contorta Bowerbank, } \\
1866 \text { (sensu Minchin 1905) }\end{array}$ & 13.80 & 45.63 & Trieste & $\begin{array}{l}\text { Lendenfeld } 1891 \text { (as Ascetta } \\
\text { spinosa) }\end{array}$ \\
\hline $\begin{array}{l}\text { Ascandra contorta Bowerbank, } \\
1866 \text { (sensu Minchin 1905) }\end{array}$ & 13.77 & 45.60 & Muggio & $\begin{array}{l}\text { Lendenfeld } 1891 \text { (as Ascetta } \\
\text { spinosa) }\end{array}$ \\
\hline $\begin{array}{l}\text { Ascandra contorta Bowerbank, } \\
1866 \text { (sensu Minchin 1905) }\end{array}$ & 16.22 & 43.01 & Island of Vis $=$ Lissa & $\begin{array}{l}\text { Lendenfeld } 1891 \text { (as Ascetta } \\
\text { spinosa) }\end{array}$ \\
\hline $\begin{array}{l}\text { Ascandra contorta Bowerbank, } \\
1866 \text { (sensu Minchin 1905) }\end{array}$ & 16.73 & 43.13 & Hvar $=$ Lesina & $\begin{array}{l}\text { Lendenfeld } 1891 \text { (as } \mathrm{Ho}- \\
\text { mandra falcata) }\end{array}$ \\
\hline Ascandra falcata Haeckel, 1872 & 13.63 & 45.08 & Rovinj & Longo \& Pronzato 2011 \\
\hline Ascandra falcata Haeckel, 1872 & 13.80 & 45.63 & Trieste & Lendenfeld 1891 \\
\hline Ascandra falcata Haeckel, 1872 & 16.73 & 43.13 & Hvar $=$ Lesina $*$ & $\begin{array}{l}\text { Haeckel 1872; Lendenfeld } \\
1891 \text { (as Homandra falcata) }\end{array}$ \\
\hline Ascandra falcata Haeckel, 1872 & 15.50 & 42.12 & Tremiti Island & $\begin{array}{l}\text { Sarà 1961; Longo \& Pron- } \\
\text { zato } 2011\end{array}$ \\
\hline Ascandra spalatensis sp. nov. & 15.21 & 44.14 & Zadar $=$ Zara $*$ & Present work \\
\hline $\begin{array}{l}\text { Borojevia cerebrum } \\
\text { (Haeckel, 1872) }\end{array}$ & 16.73 & 43.13 & Hvar $=$ Lesina $*$ & $\begin{array}{l}\text { Haeckel 1872; Lendenfeld } \\
\text { 1891; Imešek et al. } 2014\end{array}$ \\
\hline $\begin{array}{l}\text { Borojevia cerebrum } \\
\text { (Haeckel, 1872) }\end{array}$ & 16.89 & 43.40 & Vrulja Cove & Present work \\
\hline $\begin{array}{l}\text { Borojevia cerebrum } \\
\text { (Haeckel, 1872) }\end{array}$ & 13.63 & 45.08 & Rovinj & Lendenfeld 1891 \\
\hline Borojevia croatica sp. nov. & 16.37 & 43.48 & Island of Čiovo* & Present work \\
\hline $\begin{array}{l}\text { Clathrina blanca } \\
\text { (Miklucho-Maclay, 1868) }\end{array}$ & 13.62 & 45.05 & $\begin{array}{l}\text { Island of St. Giovanni } \\
\text { (near Rovinj) }\end{array}$ & Imešek et al. 2014 \\
\hline $\begin{array}{l}\text { Clathrina blanca } \\
\text { (Miklucho-Maclay, 1868) }\end{array}$ & 13.63 & 45.08 & Rovinj & Longo \& Pronzato 2011 \\
\hline $\begin{array}{l}\text { Clathrina blanca } \\
\text { (Miklucho-Maclay, 1868) }\end{array}$ & 16.73 & 43.13 & Lesina $=$ Hvar & Lendenfeld 1891 \\
\hline $\begin{array}{l}\text { Clathrina blanca } \\
\text { (Miklucho-Maclay, 1868) }\end{array}$ & 14.72 & 45.15 & Selce & Imešek et al. 2014 \\
\hline $\begin{array}{l}\text { Clathrina blanca } \\
\text { (Miklucho-Maclay, 1868) }\end{array}$ & 16.37 & 43.48 & Island of Ciovo & Imešek et al. 2014 \\
\hline
\end{tabular}


Clathrina lacunosa

(Johnston, 1842)

Clathrina lacunosa

(Johnston, 1842)

Clathrina conifera

Klautau \& Borojević, 2001

Clathrina conifera

Klautau \& Borojević, 2001

Clathrina clathrus (Schmidt, 1864)

Clathrina clathrus (Schmidt, 1864)

16.73

Clathrina clathrus (Schmidt, 1864)

Clathrina clathrus (Schmidt, 1864)

Clathrina clathrus (Schmidt, 1864)

Clathrina clathrus (Schmidt, 1864)

Clathrina clathrus (Schmidt, 1864)

Clathrina clathrus (Schmidt, 1864)

Clathrina coriacea

(Montagu, 1814)**

Clathrina coriacea

(Montagu, 1814)**

Clathrina coriacea

(Montagu, 1814)**

Clathrina primordialis

(Haeckel, 1872)

Clathrina primordialis

(Haeckel, 1872)

Clathrina primordialis

(Haeckel, 1872)

Clathrina primordialis

(Haeckel, 1872)

Clathrina primordialis

(Haeckel, 1872)

Clathrina primordialis

(Haeckel, 1872)

Clathrina primordialis

(Haeckel, 1872)

$\begin{array}{ccll}13.63 & 45.08 & \text { Rovinj } & \begin{array}{l}\text { Lendenfeld } 1891 \text { (as Ascan- } \\ \text { dra angulata) }\end{array} \\ 16.73 & 43.13 \quad \text { Hvar = Lesina } & \begin{array}{l}\text { Lendenfeld } 1891 \text { (as Ascan- } \\ \text { dra angulata) }\end{array}\end{array}$

18.142 .64 Dubrovnik Present work

$18.11 \quad 42.63 \quad$ Island of Lokrum Present work

$15.92 \quad 43.73 \quad$ Sibenik $=$ Sebenico* $\quad$ Schmidt 1864

Schmidt (according to

Haeckel 1872); Heller 1864 (apud Haeckel 1872);

Haeckel 1872

16.22 43.01 Island of Vis $=$ Lissa* Heller 1864 (apud Haeckel 1872)

$13.63 \quad 45.08$ Rovinj Imešek et al. 2014

13.62 45.05 Island of St. Giovanni Present work

16.22 43.01 Island of Vis $=$ Lissa* Present work

17.68 42.81 Prapratno Cove Present work

16.36 43.48 Island of Čiovo Present work

$13.63 \quad 45.08$ Rovinj $\quad$ Longo \& Pronzato 2011

15.5 42.12 Tremiti Island Sarà 1961; Longo \& Pronzato 2011

16.87 41.13 Bari Longo \& Pronzato 2011

Schmidt (according to Haeckel 1872); Haeckel

$16.73 \quad 43.13$ Hvar $=$ Lesina* 1872; Heller 1864 (apud Haeckel 1872); Lendenfeld 1891

$\begin{array}{llll}13.80 & 45.63 & \text { Trieste } & \text { Lendenfeld 1891 } \\ 13.77 & 45.60 & \text { Muggio } & \text { Lendenfeld 1891 }\end{array}$
Haeckel 1872); Lendenfeld 1891

Schmidt (according to

$15.92 \quad 43.73 \quad$ Šibenik $=$ Sebenico $\quad$ Haeckel 1872); Lendenfeld 1891

Schmidt (according to

16.87 42.73 Lastovo = Lagosta Haeckel 1872); Lendenfeld 1891

$16.22 \quad 43.01 \quad$ Island of Vis $=$ Lissa $\quad$ Lendenfeld 1891 
KLAUTAU M. et al., Adriatic calcarean sponges (Porifera, Calcarea)

Clathrina primordialis

(Haeckel, 1872)

Clathrina primordialis

(Haeckel, 1872)

Clathrina rubra Sarà, 1958

Clathrina rubra Sarà, 1958

Leucetta solida (Schmidt, 1862)

Leucetta solida (Schmidt, 1862)

Leucetta solida (Schmidt, 1862)

Leucetta solida (Schmidt, 1862)

Leucetta solida (Schmidt, 1862)

Leucetta solida (Schmidt, 1862)
$13.63 \quad 45.08$ Rovinj

16.36 $43.48 \quad$ Island of Čiovo

$13.63 \quad 45.08$ Rovinj

16.36 $43.48 \quad$ Island of Čiovo

15.92

16.87

16.73

43.13

Hvar $=$ Lesina

Lastovo $=$ Lagosta

$16.87 \quad 42.73 \quad$ (Zaklopatica $=$ Porto Chiave)*

$15.5 \quad 42.12$ Tremiti Island

$16.87 \quad 41.13 \quad$ Bari
Lendenfeld 1891; Imešek et al. 2014 (as Clathrina cf. hondurensis)

Present work

Imešek et al. 2014

Present work

Schmidt 1862; Lendenfeld 1891

Schmidt (according to Haeckel 1872); Lendenfeld 1891

Schmidt (according to Haeckel 1872); Haeckel 1872; Lendenfeld 1891

Schmidt 1864

Sarà 1961; Longo \& Pronzato 2011

Longo \& Pronzato 2011

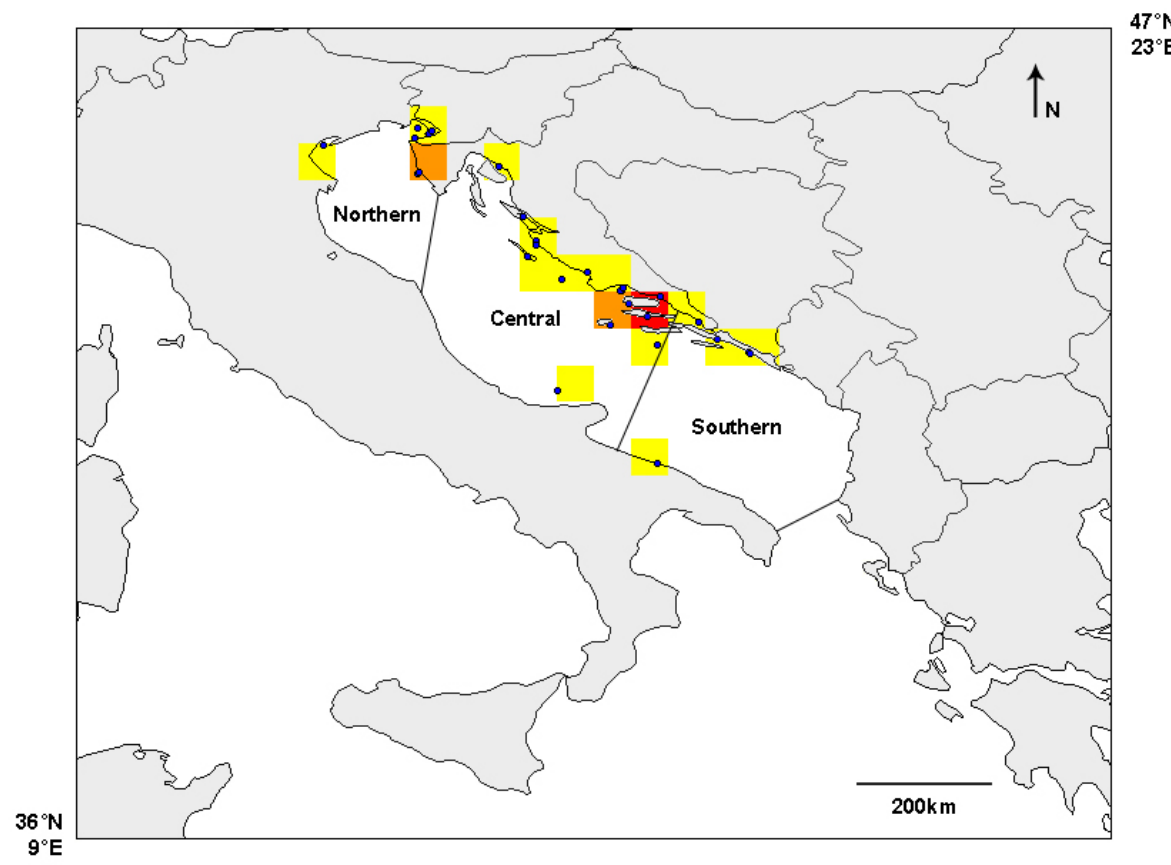

Fig. 20. Species richness in the Adriatic Sea divided by sectors. $\square$ : 1-9 species; $\square$ : 10-17 species; $18-26$ species. 
Table 13. Calcaronean species reported from the Adriatic Sea and their distribution. * = Type locality.

\begin{tabular}{|c|c|c|c|c|}
\hline Species & $\begin{array}{l}\text { Longitude } \\
\text { (N) }\end{array}$ & $\begin{array}{l}\text { Latitude } \\
\text { (E) }\end{array}$ & Locality & Source \\
\hline $\begin{array}{l}\text { Amphoriscus chrysalis } \\
\text { (Schmidt, 1864) }\end{array}$ & 16.73 & 43.13 & Hvar $=$ Lesina $*$ & $\begin{array}{l}\text { Schmidt 1864; Haeckel } \\
1872\end{array}$ \\
\hline $\begin{array}{l}\text { Amphoriscus chrysalis } \\
\text { (Schmidt, 1864) }\end{array}$ & 16.22 & 43.01 & Island of Vis $=$ Lissa $*$ & Schmidt, 1864 \\
\hline $\begin{array}{l}\text { Amphoriscus cylindrus } \\
\text { (Haeckel, 1872) }\end{array}$ & 16.73 & 43.13 & Hvar $=$ Lesina $*$ & $\begin{array}{l}\text { Haeckel 1872; Lendenfeld } \\
1891\end{array}$ \\
\hline $\begin{array}{l}\text { Amphoriscus gregori } \\
\text { (Lendenfeld, 1891) }\end{array}$ & 16.73 & 43.13 & Hvar $=$ Lesina $*$ & Lendenfeld 1891 \\
\hline $\begin{array}{l}\text { Aphroceras corticata } \\
\text { (Lendenfeld, 1891) }\end{array}$ & 16.73 & 43.13 & Hvar $=$ Lesina $*$ & Lendenfeld 1891 \\
\hline $\begin{array}{l}\text { Grantia capillosa } \\
\text { (Schmidt, 1862) }\end{array}$ & 15.92 & 43.73 & Šibenik $=$ Sebenico $*$ & Schmidt 1862 \\
\hline $\begin{array}{l}\text { Grantia capillosa } \\
\text { (Schmidt, 1862) }\end{array}$ & 13.63 & 45.08 & Rovinj & Lendenfeld 1891 \\
\hline $\begin{array}{l}\text { Grantia capillosa } \\
\text { (Schmidt, 1862) }\end{array}$ & 13.77 & 45.60 & Muggio & Lendenfeld 1891 \\
\hline $\begin{array}{l}\text { Grantia capillosa } \\
\text { (Schmidt, 1862) }\end{array}$ & 13.57 & 45.53 & Pirano & Lendenfeld 1891 \\
\hline $\begin{array}{l}\text { Grantia capillosa } \\
\text { (Schmidt, 1862) }\end{array}$ & 16.73 & 43.13 & Hvar $=$ Lesina & $\begin{array}{l}\text { Schmidt 1864; Haeckel } \\
\text { 1872; Lendenfeld } 1891\end{array}$ \\
\hline $\begin{array}{l}\text { Grantia capillosa } \\
\text { (Schmidt, 1862) }\end{array}$ & 15.92 & 43.73 & Šibenik = Sebenico & Lendenfeld 1891 \\
\hline $\begin{array}{l}\text { Leucandra aspera } \\
\text { (Schmidt, 1862) }\end{array}$ & 15.22 & 44.10 & Zadar $=$ Zara $*$ & $\begin{array}{l}\text { Schmidt 1862; Lendenfeld } \\
1891\end{array}$ \\
\hline $\begin{array}{l}\text { Leucandra aspera } \\
\text { (Schmidt, 1862) }\end{array}$ & 15.50 & 42.12 & Tremiti Island & $\begin{array}{l}\text { Sarà,1961; Longo \& Pron- } \\
\text { zato } 2011\end{array}$ \\
\hline $\begin{array}{l}\text { Leucandra aspera } \\
\text { (Schmidt, 1862) }\end{array}$ & 16.22 & 43.01 & Island of Vis $=$ Lissa $*$ & $\begin{array}{l}\text { Heller } 1864 \text { (apud Haeckel } \\
\text { 1872); Lendenfeld } 1891\end{array}$ \\
\hline $\begin{array}{l}\text { Leucandra aspera } \\
\text { (Schmidt, 1862) }\end{array}$ & 15.92 & 43.73 & Šibenik = Sebenico & $\begin{array}{l}\text { Schmidt 1862; Lendenfeld } \\
1891\end{array}$ \\
\hline $\begin{array}{l}\text { Leucandra aspera } \\
\text { (Schmidt, 1862) }\end{array}$ & 16.87 & 42.73 & Lastovo $=$ Lagosta & $\begin{array}{l}\text { Schmidt 1862; Lendenfeld } \\
1891\end{array}$ \\
\hline $\begin{array}{l}\text { Leucandra aspera } \\
\text { (Schmidt, 1862) }\end{array}$ & 16.73 & 43.13 & Hvar $=$ Lesina & $\begin{array}{l}\text { Schmidt 1862; Haeckel } \\
\text { 1872; Lendenfeld } 1891\end{array}$ \\
\hline Leucandra falakra sp. nov. & 15.57 & 43.63 & Blitvenica* & Present work \\
\hline Leucandra spinifera sp. nov. & 16.36 & 43.48 & Island of Čiovo & Present work \\
\hline Leucandra spinifera sp. nov. & 16.89 & 43.40 & Vrulja Cove* & Present work \\
\hline $\begin{array}{l}\text { Leucosolenia goethei } \\
\text { Haeckel, } 1870\end{array}$ & 13.63 & 45.08 & Rovinj & Lendenfeld 1891 \\
\hline $\begin{array}{l}\text { Leucosolenia variabilis Haec- } \\
\text { kel, } 1870\end{array}$ & 13.63 & 45.08 & Rovinj & Longo \& Pronzato 2011 \\
\hline Paraleucilla dalmatica sp. nov. & 16.36 & 43.48 & Island of Čiovo & Present work \\
\hline $\begin{array}{l}\text { Paraleucilla magna Klautau, } \\
\text { Monteiro \& Borojević, } 2004\end{array}$ & 17.43 & 43.05 & Port of Ploče & Cvitković et al. 2013 \\
\hline $\begin{array}{l}\text { Paraleucilla magna Klautau, } \\
\text { Monteiro \& Borojević, } 2004\end{array}$ & 16.39 & 43.51 & Port of Ploče & Present work \\
\hline
\end{tabular}


KLAUTAU M. et al., Adriatic calcarean sponges (Porifera, Calcarea)

Paraleucilla magna Klautau, Monteiro \& Borojević, 2004

Polejaevia telum

(Lendenfeld, 1891)

Sycantha tenella

Lendenfeld, 1891

Sycetta conifera

(Haeckel, 1872)

Sycon ancora sp. nov.

Sycon ancora sp. nov.

Sycon elegans

(Bowerbank, 1845)

Sycon helleri

(Lendenfeld, 1891)

Sycon humboldti Risso, 1826

Sycon humboldti Risso, 1826

Sycon humboldti Risso, 1826

Sycon humboldti Risso, 1826

Sycon humboldti Risso, 1826

Sycon quadrangulatum

(Schmidt, 1868)

Sycon quadrangulatum

(Schmidt, 1868)

Sycon quadrangulatum

(Schmidt, 1868)

Sycon raphanus Schmidt, 1862

Sycon raphanus Schmidt, 1862

Sycon raphanus Schmidt, 1862

Sycon raphanus Schmidt, 1862

Sycon raphanus Schmidt, 1862

Sycon raphanus Schmidt, 1862

Sycon schmidt (Haeckel, 1872)

Sycon schmidt (Haeckel, 1872)

Sycon setosum Schmidt, 1862

Sycon setosum Schmidt, 1862
15.22

15.92

42.75

16.73

16.73

16.48

16.73

13.8

16.73

15.04

16.39

15.50

16.73

42.75

16.22

16.73

12.34

15.10

13.61

16.73

16.22

13.63

16.73

16.87

13.8

45.63 Trieste

16.22

43.13

45.63 Trieste

$43.51 \quad$ Split

45.44 Venice

45.68

45.08 Rovin
43.29 Island of Brač

Hvar $=$ Lesina

43.13 Hvar $=$ Lesina

44.48 Island of Pag*

42.12 Tremiti Island

43.13 Hvar $=$ Lesina

16.87 Lastovo $=$ Lagosta

43.01 Island of Vis $=$ Lissa

43.13 Hvar = Lesina

43.93 Dugi otok $=$ Isola Grossa

Dalmatia, Gulf of Trieste

43.13 Hvar $=$ Lesina

43.01 Island of $\mathrm{Vis}=$ Lissa

43.13 Hvar = Lesina

41.13 Bari

$44.10 \quad$ Zadar $=$ Zara

43.73 Šibenik $=$ Sebenico

16.87 Lastovo $=$ Lagosta

43.13 Hvar $=$ Lesina*

43.13 Hvar $=$ Lesina

43.01 Island of Vis = Lissa
Present work

Lendenfeld 1891

Lendenfeld 1891

Haeckel 1872; Lendenfeld 1891

Present work

Present work

Sarà 1961

Lendenfeld 1891

Schmidt 1862

Heller 1864 (apud Haeckel 1872); Schmidt 1862

Schmidt 1862; Haeckel 1872

Martens 1824

(apud Haeckel 1872)

Martens 1824 (apud Haekkel 1872)

Schmidt, 1868

Haeckel 1872

Heller 1864 (apud Haeckel 1872)

Longo \& Pronzato 2011

Schmidt 1862; Haeckel 1872

Longo \& Pronzato 2011

Lieberkühn 1859

(apud Haeckel 1872); Schmidt, 1862 (as S. ciliatum); Haeckel 1872

Schmidt 1862

Schmidt 1862

Schmidt 1862 (apud Haekkel 1872); Haeckel 1872

Haeckel 1872

Heller 1864 (apud Haeckel 1872); Haeckel, 1872

Heller 1864 (apud Haeckel 1872) 


\begin{tabular}{|c|c|c|c|c|}
\hline Sycon setosum Schmidt, 1862 & 13.63 & 45.08 & Rovinj & Longo \& Pronzato 2011 \\
\hline Sycon tuba (Lendenfeld, 1891) & 13.8 & 45.63 & Trieste* & Lendenfeld 1891 \\
\hline Sycyssa huxleyi Haeckel, 1872 & 16.73 & 43.13 & Hvar $=$ Lesina $*$ & Haeckel 1872 \\
\hline Ute glabra Schmidt, 1864 & 16.73 & 43.13 & Hvar $=$ Lesina & $\begin{array}{l}\text { Haeckel 1872; Lendenfeld } \\
1891\end{array}$ \\
\hline Ute glabra Schmidt, 1864 & 16.22 & 43.01 & Island of Vis $=$ Lissa & $\begin{array}{l}\text { Heller } 1864 \text { (apud Haeckel } \\
\text { 1872) }\end{array}$ \\
\hline Ute glabra Schmidt, 1864 & 16.87 & 42.73 & $\begin{array}{l}\text { Lastovo = Lagosta } \\
\text { (Zaklopatica = Porto } \\
\text { Chiave)* }\end{array}$ & Schmidt 1864 \\
\hline
\end{tabular}

Our results indicate Sycon to be the most diverse genus, with nine species, followed by Clathrina with six species. However, it is important to consider that Sycon is not a monophyletic genus. It is very difficult to identify Sycon species unequivocally, as most of them have a similar spicule composition - diactines, trichoxeas and triactines in the distal cones, tubar triactines, subatrial triactines and tetractines, and atrial tetractines. To date there have been no studies on the intraspecific morphological variability of Sycon. In addition, most species were poorly described and insufficiently analyzed on the molecular level, which also applies to the calcaronean genera Paraleucilla, Leucandrilla, Leucandra and Leucilla. Molecular phylogenetic studies including as many species as possible would be very desirable to evaluate the limits between these genera. Hence, new calcaronean species are welcome to facilitate more thorough revision of their systematics and to link the molecular traits to the phylogenetically important morphological traits.

We have also confirmed the presence of a few species known so far only from the Atlantic. It was unexpected to find Clathrina conifera in the Adriatic Sea, as this species was first described along the Brazilian coast and was considered endemic (Klautau et al. 1994). Our finding raises the question whether this species was ever truly endemic for Brazil. Since Adriatic calcarean sponges are vastly unexplored and $C$. conifera is part of the $C$. primordialis species complex, it is possible that it has been recorded previously as C. primordialis (or C. coriacea). In 2010, a specimen of Clathrina conifera was observed for the first time in the Southern Adriatic, near the Island of Lokrum, and a year later, more than 20 specimens were recorded near the city of Dubrovnik. As both locations are close to the area in Dubrovnik frequently visited by cruise ships, it is possible that this species has been introduced into the Adriatic. However, if this species arrived by anthropogenic means, we cannot state whether it arrived from the Western Atlantic to the Adriatic or vice-versa. It is important to mention that Paraleucilla magna is also present in the Southern Adriatic (Cvitković et al. 2013). It was first recorded in Brazil in the 1980's; however, the origin of this species is unknown. It seems to have been introduced by anthropogenic means into the Mediterranean (Longo et al. 2007) and to have spread into the Eastern Mediterranean, including the Adriatic Sea. Here, we molecularly confirm the presence of $P$. magna near the Port of Ploče and at a new location, near the Island of Brač (Table 13).

The molecular analyses revealed some interesting taxonomic traits. At the generic level, the monophyletic clade of former guanchas indicates that the development of a peduncle and of parasagittal spicules probably appeared only once in the evolution of Clathrina. Clathrina hispanica was nested within this group, although in the original description of this species neither peduncle nor parasagittal spicules were mentioned (Klautau \& Valentine 2003). The type specimen of this species is fragmented, resulting in the impossibility of confirming if a peduncle was present or not; however, we re-analysed the slides of the holotype and found some parasagittal spicules. Another interesting result indicated the close relationship 
among Ascandra, Soleneiscus and Levinella revealed in the 28S analysis. Voigt et al. (2012) showed that the genus Ascandra is closely related to Soleneiscus and Levinella, which is now confirmed by our results. This implies that in the future the genera Levinella and Soleneiscus might be synonymised with the genus Ascandra; nonetheless, more detailed molecular and morphological analyses on a larger number of specimens and species are needed to confirm this action. At the species level, the molecularly confirmed presence of Clathrina conifera in the Adriatic raises a doubt of the earlier identification of the $C$. primordialis syntype, allowing the selection of a true lectotype of this species. Additionally, the re-description of Borojevia cerebrum, based on a molecular analysis of specimens discovered near its type locality (Lesina - Island of Hvar), confirmed the presence of this species in the Mediterranean Sea (Table 1; Fig. 16). Observing the morphological variations within a single, molecularly verified species, enabled the synonymization of two "cerebrum" varieties. Step by step, the "cerebrum complex" is being solved. All this again confirms that molecular verification of morphological traits is very important for a proper species assignment. It goes hand in hand with morphological confirmation relying on the type specimens, which often become deteriorated or even lost, without detailed descriptions. This review of some of the first species of calcarean sponges, that were last recorded and described by Haeckel in the $19^{\text {th }}$ century, allowed validation of their taxonomic status at the molecular and morphological levels. It bears a significant weight in reviving museum collections, which would be of a great help for systematics research of calcarean sponges in the future.

\section{Acknowledgements}

M.I., B.P. and H.Ć. were funded by the Croatian Ministry of Science, Education and Sports (MSES) grant 098-0982913-2874. V.N. was funded by the Croatian MSES grant 001-0000000-3203. M.K. is funded by fellowships and research grants from the Brazilian National Research Council (CNPq), the Rio de Janeiro State Research Foundation (Fundação Carlos Chagas Filho de Amparo à Pesquisa do Estado do Rio de Janeiro - FAPERJ) and Coordination for the Improvement of Higher Education Personnel (CAPES). F.A. has a fellowship from CAPES. We are grateful to Anne Frijsinger and Mat Vestjens for collecting and Diana Trnski for bringing in the samples of $C$. blanca. Jelena Godrijan is acknowledged for helping with the preliminary SEM analysis of C. cerebrum.

\section{References}

Arndt W. 1941. Eine neuere Ausbeute von Meeresschwämmen der West- und Südküste Portugals. Memórias do Museu de Zoologia da Universidade de Coimbra 116: 1-75.

Arnesen E. 1901. Spongier fra den norske kyst. I. Calcarea. Systematisk katalog med bemerkninger og bestemmelsestabell. Bergen Museums Árbok 1900: 1-44.

Bianchi C.N. \& Morri C. 2000. Marine biodiversity of the Mediterranean Sea: Situation, problems and prospects for future research. Marine Pollution Bulletin 40: 367-376. http://dx.doi.org/10.1016/S0025$\underline{326 \mathrm{X}(00) 00027-8}$

Bianchi C.N., Morri C., Chiantore M., Montefalcone M., Parravicini V. \& Rovere, A. 2012. Mediterranean Sea biodiversity between the legacy from the past and a future of change. In: Stambler N. (ed.) Life in the Mediterranean Sea: A Look at Habitat Changes: 1-55. Nova Science Publishers, Inc., New York.

Bianco S.L.O. 1888. Notizie biologiche riguardanti specialmente il periodo di maturità sessuale degli animali del golfo di Napoli. Mitteilungen aus der Zoologischen Station zu Neapel 8: 385-440.

Bidder G.P. 1891. Review of "A Monograph of Victorian Sponges”. Quarterly Journal of Microscopical Science 32: 625-632.

Borojević R. 1967. Spongiaires d'Afrique du Sud (2) Calcarea. Transactions of the Royal Society of South Africa 37: 183-226. 
Borojević R. 1971. Éponges calcaires des côtes du Sud-Est du Brésil, épibiontes sur Laminaria brasiliensis et Sargassum cymosum. Revista Brasileira de Biologia 31: 525-530.

Borojević R. \& Peixinho S. 1976. Éponges calcaires du nord-nord-est du Brésil. Bulletin du Muséum national d'Histoire naturelle 3(402): 987-1036.

Borojević R. \& Boury-Esnault N. 1987. Calcareous sponges collected by N.O. Thalassa on the continental margin of the Bay of Biscaye: I. Calcinea. In: Vacelet J. \& Boury-Esnault N. (eds) Taxonomy of Porifera from the NE Atlantic and Mediterranean Sea: 1-27. NATO Asi Series G13.

Borojević R., Cabioch L. \& Lévi C. 1968. Inventaire de la Faune marine de Roscoff: Spongiaires. Éditions de la Station Biologique de Roscoff, France.

Bouzon J.L., Brandini F.P \& Rocha R.M. 2012. Biodiversity of sessile fauna on rocky shores of coastal islands in Santa Catarina, Southern Brazil. Marine Science 2(5): 39-47. http://dx.doi.org/ 10.5923/j. ms.20120205.01

Breitfuss L.L. 1897a. Ascandra hermesi, ein neuer homocoeler Kalkschwamm aus der Adria. Zeitschrift für Wissenschaftliche Zoologie 63(1): 39-42.

Breitfuss L.L. 1897b. Catalog der Calcarea der zoologischen Sammlung des königlichen Museums für Naturkunde zu Berlin. Archiv für Naturgeschichte 63: 205-226.

Breitfuss L.L. 1898a. Kalkschwammfauna des Weissen Meeres und der Eismeerküsten des europäischen Russlands. Mémoires de l'Académie Imperiale des Sciences de St. Pétersbourg 6(2): 1-41.

Breitfuss L.L. 1898b. Kalkschwammfauna der Westküste Portugals. Zoologische Jahrbücher 2: 89-102.

Breitfuss L.L. 1898c. Kalkschwämme von Ternate. Abhandlungen der Senckenbergischen Naturforschenden Gesellschaft 24: 169-178.

Breitfuss L.L. 1930. Biogeographischer Beitrag zur Kenntniss der Spongienfauna der Arktis. Sitzungsberichte der Gesellschaft Naturforschender Freunde zu Berlin 1929: 274-282.

Breitfuss L.L. 1932. Die Kalkschwammfauna des arktischen Gebietes. Fauna Arctica 6: 235-252.

Breitfuss L.L. 1935. La spugne calcarea dell'Adriatico con riflesso a tutto i1 Mediterraneo. Memorie Reale Comitato Talassographico Italiano 2223: 1-45.

Brøndsted H.V. 1914. Catalogue of the Porifera of Greenland. Meddelelser Om Grönland 23: 457-544.

Brøndsted H.V. 1931. Die Kalkschwämme. Deutsche Südpolar Expedition 1901-03 20: 1-47.

Burton M. 1926. Report on the sponges. Transactions of the Zoological Society of London 22: 71-83. http://dx.doi.org/10.1111/j.1096-3642.1926.tb00322.x

Burton M. 1933. Report on a small collection of sponges from Still Bay, S. Africa. Annals and Magazine of Natural History 12: 235-244.

Burton M. 1963. A Revision of the Classification of the Calcareous Sponges. British Museum, London.

Carter H.J. 1886. Descriptions of the sponges from the neighbourhood of Port Philip Heads, South Australia. Annals and Magazine of Natural History 5(18): 502-516.

Castresana J. 2000. Selection of conserved blocks from multiple alignments for their use in phylogenetic analysis. Molecular Biology and Evolution 17: 540-552. http://dx.doi.org/10.1093/oxfordjournals. molbev.a026334

Custódio M.R. \& Hajdu E. 2011. Checklist de Porifera do Estado de São Paulo, Brasil. Biota Neotropica 11(1a): $1-17$. 
Cvitković I., Despalatović M., Grubelić I., Nikolić V., Pleše B. \& Žuljević A. 2013. Occurrence of Paraleucilla magna (Porifera: Calcarea) in the eastern Adriatic Sea. Acta Adriatica: International Journal of Marine Sciences 54(1): 93-99.

Darriba D., Taboada G.L., Doallo R. \& Posada D. 2012. jModelTest 2: more models, new heuristics and parallel computing. Nature Methods 9 (8): 772. http://dx.doi.org/10.1038/nmeth.2109

Dendy A. \& Row H. 1913. The classification and phylogeny of the calcareous sponges, with a reference list of all the described species, systematically arranged. Proceedings of the Zoological Society of London 47: 704-813. http://dx.doi.org/10.1111/j.1469-7998.1913.tb06152.x

Dohrmann M., Voigt O., Erpenbeck D. \& Wörheide G. 2006. Non-monophyly of most supraspecific taxa of calcareous sponges (Porifera, Calcarea) revealed by increased taxon sampling and partitioned Bayesian analysis of ribosomal DNA. Molecular Phylogenetics and Evolution 40: 830-843. http:// dx.doi.org/10.1016/j.ympev.2006.04.016

Ferrer Hernández F. 1918. Esponjas del litoral de Asturias. Trabajos del Museo nacional de ciencias de Madri (Zoológica) 36: 1-39.

Guindon S. \& Gascuel O. 2003. A simple, fast and accurate method to estimate large phylogenies by maximum-likelihood. Systematic Biology 52: 696-704. http://dx.doi.org/10.1080/10635150390235520

Guindon S., Dufayard J.F., Lefort V., Anisimova M., Hordijk W. \& Gascuel O. 2010. New algorithms and methods to estimate maximum-likelihood phylogenies: Assessing the performance of PhyML 3.0. Systematic Biology 59(3): 307-321. http://dx.doi.org/10.1093/sysbio/syq010

Haeckel E. 1870. Prodromus eines Systems der Kalkschwämme. Jenaische Zeitschrift für Medicin und Naturwissenschaft 5: 236-254.

Haeckel E. 1872. Die Kalkschwämme, eine Monographie. Vols 1-3. Reimer, Berlin.

Harcet M., Bilandžija H., Bruvo-Mađarić B. \& Ćetković H. 2010. Taxonomic position of Eunapius subterraneus (Porifera, Spongillidae) inferred from molecular data - a revised classification needed? Molecular Phylogenetics and Evolution 54: 1021-1027. http://dx.doi.org/10.1016/j.ympev.2009.12.019

Heller C. 1864. Horae dalmatinae. Bericht über eine Reise nach der Ostküste des adriatischen Meeres. Verhandlungen der zoologisch-botanischen Gesellschaft in Wien 14: 17-64.

Hijmans R.J., Guarino L. \& Mathur P. 2012. DIVAGIS, Version 7.5. A geographic information system for the management and analysis of genetic resources data. Manual. International Potato Center, Lima, Peru.

Hôzawa S. 1940. On some calcareous sponges from Japan. Science Reports of the Tôhoku Imperial University 15: 29-58.

Huelsenbeck J.P. \& Ronquist F. 2001. MrBayes: Bayesian inference of phylogenetic trees. Bioinformatics 17: 754-755. http://dx.doi.org/10.1093/bioinformatics/17.8.754

Imešek M., Pleše B., Pfannkuchen M., Godrijan J., Pfannkuchen D.M., Klautau M. \& Ćetković H. 2014. Integrative taxonomy of four Clathrina species of the Adriatic Sea, with the first formal description of Clathrina rubra Sarà, 1958. Organisms Diversity \& Evolution 14(1): 21-29. http://dx.doi.org/10.1007/ $\underline{\text { s13127-013-0156-0 }}$

Jenkin C.F. 1908. The marine fauna of Zanzibar and British East Africa from collections made by Cyril Crossland, M.A., in the years 1901 and 1902. Proceedings of the Zoological Society of London 434-456. http://www.biodiversitylibrary.org/item/99643\# 
Katoh S. \& Standley D.M. 2013. MAFFT multiple sequence alignment software version 7: Improvements in performance and usability. Molecular Biology and Evolution 30: 772-780. http://dx.doi.org/10.1093/ molbev/mst010

Kirk H.B. 1896. New Zealand sponges. Third paper. Transactions of the New Zealand Institute 28: 205-210. http://www.biodiversitylibrary.org/item/22752\#

Klautau M. \& Borojević R. 2001. Calcareous sponges from Arraial do Cabo - Brazil (I: the genus Clathrina). Zoosystema 23: 395-410.

Klautau M. \& Valentine C. 2003. Revision of the genus Clathrina (Porifera, Calcarea). Zoological Journal of the Linnean Society 139: 1-62. http://dx.doi.org/10.1046/j.0024-4082.2003.00063.x

Klautau M., Solé-Cava A.M. \& Borojević R. 1994. Biochemical systematics of sibling sympatric species of Clathrina (Porifera: Calcarea). Biochemical Systematics and Ecology 22: 367-375. http://dx.doi. org/10.1016/0305-1978(94)90027-2

Klautau M., Azevedo F., Báslavi C.-L., Rapp H.T., Collins A. \& Russo C.A.M. 2013. A molecular phylogeny for the order Clathrinida rekindles and refines Haeckel's taxonomic proposal for calcareous sponges. Integrative and Comparative Biology 53 (3): 447-461. http://dx.doi.org/10.1093/icb/ict039

Lackschewitz P. 1886. Über die Kalkschwämme Menorcas. Zoologische Jahrbücher 1: 297-310. http:// www.biodiversitylibrary.org/item/38121\#

Lanna E., Rossi A.L., Cavalcanti F.F., Hajdu E. \& Klautau M. 2007. Calcareous sponges from São Paulo State, Brazil (Porifera: Calcarea: Calcinea) with the description of two new species. Journal of the Marine Biological Association of the United Kingdom 87: 1553-1561. http://dx.doi.org/10.1017/ $\underline{\mathrm{S} 0025315407056871}$

Lendenfeld R. von 1885. The Homocoela of Australia and the new family Homodermidae. Proceedings of the Linnean Society of New South Wales 9: 896-907. http://www.biodiversitylibrary.org/item/82331\# Lendenfeld R. von 1891. Die Spongien der Adria. I. Die Kalkschwämme. Wilhelm Engelmann, Leipzig. Lieberkühn N. 1859. Neue Beiträge zur Anatomie der Spongien. Archiv für Anatomie und Physiologie 30 (3): 353-382, 515-529.

Lôbo-Hajdu G., Guimarães A.C.R., Salgado A., Lamarão F.R.M., Vieiralves T., Mansure J.J. \& Albano R.M. 2004. Intragenomic, intra- and interspecific variation in the rDNA ITS of Porifera revealed by PCR single-strand conformation polymorphism (PCR-SSCP). Bollettino dei Musei e degli Istituti Biologici dell'Universitá di Genova 68: 413-423.

Longo C. \& Pronzato R. 2011. Class Calcarea. In: Pansini M., Manconi R. \& Pronzato R. (eds) Fauna d'Italia - Porifera I-Calcarea, Demospongiae (partim), Hexactinellida, Homoscleromorpha: 117-244. Calderini, Bologna.

Longo C., Mastrototaro F. \& Corriero G. 2007. Occurrence of Paraleucilla magna (Porifera: Calcarea) in the Mediterranean Sea. Journal of the Marine Biological Association of the United Kingdom 87: 1749-1755. http://dx.doi.org/10.1017/S0025315407057748

Martens G.M. von. 1824. Reise nach Venedig. 2 Volumes. Stettin'sche Buchhandlung, Ulm.

Minchin E.A. 1896. Suggestions for a natural classification of the Asconidae. Annals and Magazine of Natural History 18: 349-362.

Minchin E.A. 1905. On the sponges Leucosolenia contorta Bowerbank, Ascandra contorta Haeckel, and Ascetta spinosa Lendenfeld. Proceedings of the Zoological Society of London 2: 1-20. 
Monteiro L.C. \& Muricy G. 2004. Patterns of sponge distribution in Cagarras Arquipelago, Rio de Janeiro, Brazil. Journal of the Marine Biological Association of the United Kingdom 84 (4): 681-687. http://dx.doi.org/10.1017/S0025315404009750h

Mothes-de-Moraes B. 1985. Sponges collected by the Oxford diving expedition to the Cabo Frio upwelling area (Rio de Janeiro, Brasil). Studies on Neotropical Fauna and Environment 20 (4): 227 237. http://dx.doi.org/10.1080/01650528509360694

Muricy G. \& Hajdu E. 2006. Porifera Brasilis: Guia de Identificação das Esponjas mais comuns do Sudeste do Brasil. Série Livros 17, Museu Nacional, Rio de Janeiro.

Muricy G. \& Silva O.C. 1999. Esponjas marinhas do Estado do Rio de Janeiro: um recurso renovável inexplorado. In: Silva S.H.G \& Lavrado H.P. (eds) Ecologia dos Ambientes Costeiros do Estado do Rio de Janeiro. Série Oecologia Brasiliensis 7: 155-178.

Muricy G., Lopes D.A., Hajdu E., Carvalho M.S., Moraes F.C., Klautau M., Menegola C. \& Pinheiro U. 2011. Catalogue of Brazilian Porifera. Museu Nacional, Rio de Janeiro.

Nichols S.A. 2005. An evaluation of support for order-level monophyly and interrelationships within the class Demospongiae using partial data from the large subunit rDNA and cytochrome oxidase subunit I. Molecular Phylogenetics and Evolution 34 (1): 81-96. http://dx.doi.org/10.1016/j.ympev.2004.08.019

Pansini M. \& Longo C. 2008. Porifera. In: Relini G. (ed.) Checklist della Flora e della Fauna dei Mari Italiani (Parte I): 42-66. Biologia Marina Mediterranea 15 suppl. (1).

Rossi A.L., Russo C.A.M., Solé-Cava A.M., Rapp H.T. \& Klautau M. 2011. Phylogenetic signal in the evolution of body colour and spicule skeleton in calcareous sponges. Zoological Journal of the Linnean Society 163: 1026-34. http://dx.doi.org/10.1111/j.1096-3642.2011.00739.x

Row R.W.H. 1909. Reports on the marine biology of the Sudanese Red Sea. XIX. Report on the Sponges collected by Mr Cyril Crossland in 1904-05. Journal of the Linnean Society of London, Zoology 31: 182-214. http://www.biodiversitylibrary.org/item/98662\#

Row R.W.H. \& Hôzawa S. 1931. Report on the Calcarea obtained by the Hamburg South-West Australian Expedition of 1905. Science Reports of the Tôhoku University 6: 727-809.

Sarà M. 1961. La fauna di poriferi delle grotte delle isole Tremiti. Studio ecologico e sistematico. Archivo Zoologico Italiano 46: 1-59.

Schmidt O. 1862. Die Spongien des Adriatischen Meeres, enthaltend die Histologie und systematiche Ergänzungen. Wilhelm Engelmann, Leipzig.

Schmidt O. 1864. Supplement der Spongien des Adriatischen Meeres, enthaltend die Histologie und systematische Ergänzungen. Wilhelm Engelmann, Leipzig.

Schmidt O. 1866. Zweites Supplement der Spongien des Adriatischen Meeres, enthaltend die Vergleichung der Adriatischen und Britischen Spongiengattungen. Wilhelm Engelmann, Leipzig.

Schmidt O. 1868. Die Spongien der Küste von Algier (Drittes Supplement). Wilhelm Engelmann, Leipzig.

Schmidt O. 1869. Vorläufige Mitteilungen über die Spongien der Grönländischen Küste. Mitteilungen des naturwissenschaftlichen Vereins für Steiermark 2: 89-97.

Schmidt O. 1870. Grundzüge einer Spongienfauna des atlantischen Gebietes. Wilhelm Engelmann, Leipzig. 
Solé-Cava A.M., Klautau M., Boury-Esnault N., Borojević R. \& Thorpe J.P. 1991. Genetic evidence for cryptic speciation in allopatric populations of two cosmopolitan species of the calcareous sponge genus Clathrina. Marine Biology 111 (3): 381-386. http://dx.doi.org/10.1007/BF01319410

Spalding M.D., Fox H.E., Allen G.R., Davidson N., Ferdaña Z.A., Finlayson M., Halpern B.S., Jorge M.A., Lombana A., Lourie S.A., Martin K.D., McManus E., Molnar J., Recchia C.A. \& Robertson J. 2007. Marine ecoregions of the world: a bioregionalization of coastal and shelf areas. BioScience 57: 573-583. http://dx.doi.org/10.1641/B570707

Tanita S. 1942. Key to all the described species of the genus Leucosolenia and their distribution. Science Reports of the Tôhoku Imperial University 17: 71-93.

Tanita S. 1943. Studies on the Calcarea of Japan. Science Reports of the Tohoku Imperial University 17 (4): 353-490.

Topsent E. 1934. Aperçu de la faune des éponges calcaires de la Mediterranée. Bulletin de l'Institut Océanographique de Monaco 659: 1-20.

Topsent E. 1936. Étude sur les Leucosolenia. Bulletin de l'Institut Océanographique de Monaco 711: $1-47$.

Voigt O., Wülfing E. \& Wörheide G. 2012. Molecular phylogenetic evaluation of classification and scenarios of character evolution in calcareous sponges (Porifera, Class Calcarea). PLoS ONE 7(3): e33417. http://dx.doi.org/10.1371/journal.pone.0033417

Wörheide G. \& Hooper J.N.A. 1999. Calcarea from the Great Barrier Reef. I: Cryptic Calcinea from Heron Island and Wistari Reef (Capricorn-Bunker group). Memoirs of the Queensland Museum 43: 859-891.

Manuscript received: 17 September 2015

Manuscript accepted: 17 November 2015

Published on: 2 March 2016

Topic editor: Rudy Jocqué

Desk editor: Kristiaan Hoedemakers

Printed versions of all papers are also deposited in the libraries of the institutes that are members of the EJT consortium: Muséum national d'Histoire naturelle, Paris, France; Botanic Garden Meise, Belgium; Royal Museum for Central Africa, Tervuren, Belgium; Natural History Museum, London, United Kingdom; Royal Belgian Institute of Natural Sciences, Brussels, Belgium; Natural History Museum of Denmark, Copenhagen, Denmark. 